\title{
Washington Metropolitan Area Transit Authority: Compressed Natural Gas Transit Bus Evaluation
}

K. Chandler and E. Eberts Battelle

M. Melendez National Renewable Energy Laboratory

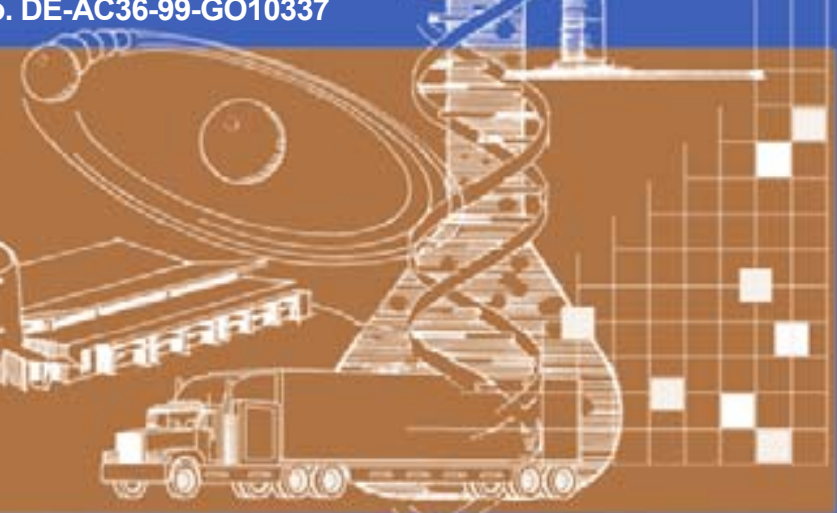




\section{Washington Metropolitan Area Transit Authority: Compressed Natural Gas Transit Bus Evaluation}

K. Chandler and E. Eberts Battelle

M. Melendez

National Renewable Energy Laboratory

Prepared under Task No. FC05.9000

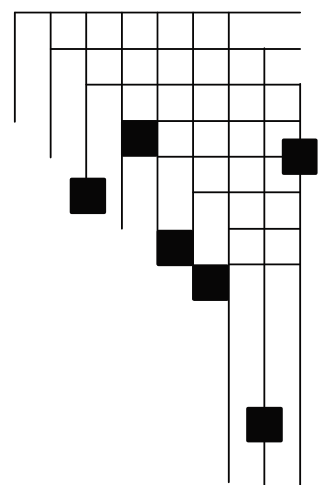




\section{NOTICE}

This report was prepared as an account of work sponsored by an agency of the United States government. Neither the United States government nor any agency thereof, nor any of their employees, makes any warranty, express or implied, or assumes any legal liability or responsibility for the accuracy, completeness, or usefulness of any information, apparatus, product, or process disclosed, or represents that its use would not infringe privately owned rights. Reference herein to any specific commercial product, process, or service by trade name, trademark, manufacturer, or otherwise does not necessarily constitute or imply its endorsement, recommendation, or favoring by the United States government or any agency thereof. The views and opinions of authors expressed herein do not necessarily state or reflect those of the United States government or any agency thereof.

Available electronically at http://www.osti.gov/bridge

Available for a processing fee to U.S. Department of Energy and its contractors, in paper, from:

U.S. Department of Energy

Office of Scientific and Technical Information

P.O. Box 62

Oak Ridge, TN 37831-0062

phone: 865.576 .8401

fax: 865.576 .5728

email: mailto:reports@adonis.osti.gov

Available for sale to the public, in paper, from:

U.S. Department of Commerce

National Technical Information Service

5285 Port Royal Road

Springfield, VA 22161

phone: 800.553 .6847

fax: 703.605.6900

email: orders@ntis.fedworld.gov

online ordering: http://www.ntis.gov/ordering.htm 


\section{Foreword}

This evaluation would not have been possible without the support and guidance from staff at Washington Metropolitan Area Transit Authority, including the following:

- Jack Requa

- Phillip Wallace

- Robert Golden

- Sebastian Silvani (contractor from Booz Allen Hamilton)

- Barry Goldman

- John Smith.

The authors wish to acknowledge the leadership and input from Dennis Smith at the U.S. Department of Energy, and the contributions to this evaluation from New Flyer, Cummins Westport, Inc., John Deere, and Hanover.

This report is available from the National Renewable Energy Laboratory in PDF at www.nrel.gov/docs/fy06osti/37626.pdf.

Kevin Chandler and Erin Eberts

Battelle
Margo Melendez

National Renewable Energy Laboratory 


\section{Table of Contents}

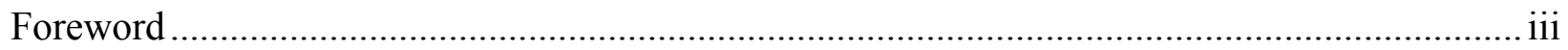

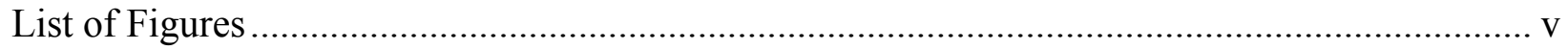

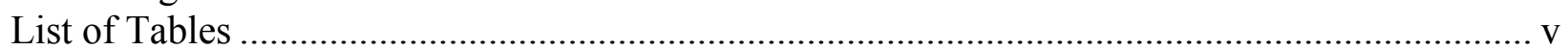

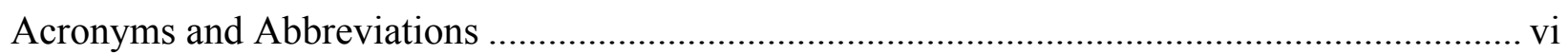

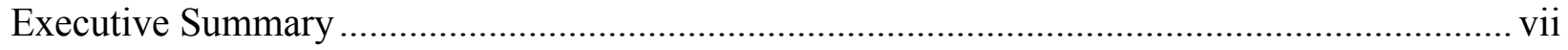

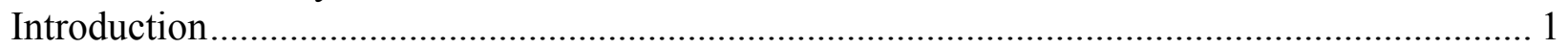

Fleet Profile: Washington Metropolitan Transit Authority .................................................... 3

Emission Reduction Programs ................................................................................. 3

Compressed Natural Gas Bus Program................................................................... 4

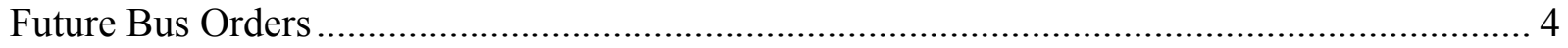

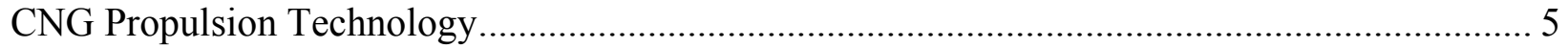

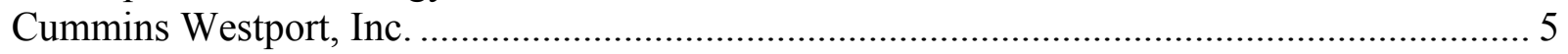

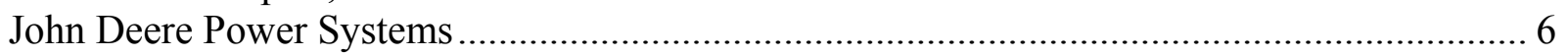

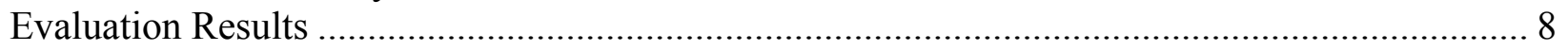

Vehicle System Descriptions .................................................................................. 9

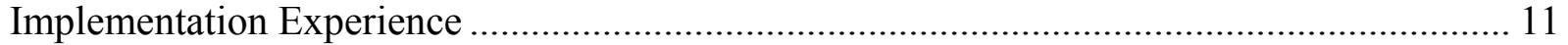

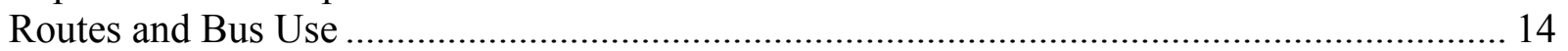

Fuel Consumption, Economy, and Cost ..................................................................... 16

Maintenance Costs by Vehicle System ....................................................................... 23

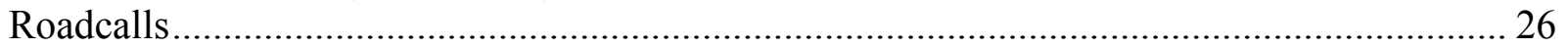

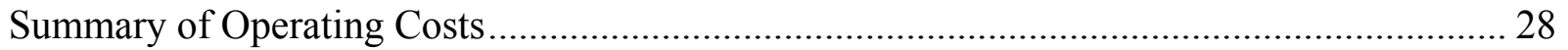

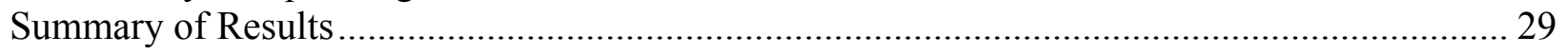

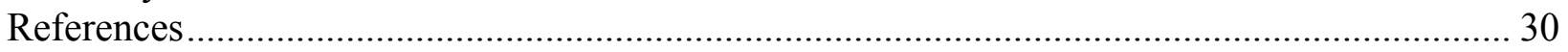

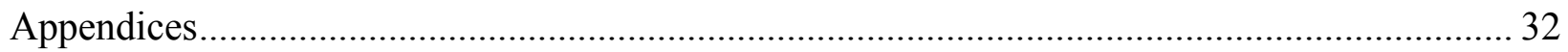




\section{List of Figures}

Figure 1. Results of 2002 WMATA Emission Testing, Central Business District Cycle ............. 2

Figure 2. WMATA CNG Transit Bus................................................................................. 2

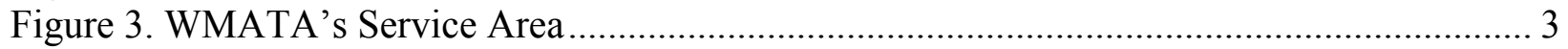

Figure 4. CWI C Gas Plus Engine ................................................................................. 6

Figure 5. John Deere Power Systems 6081H Natural Gas Engine ............................................. 7

Figure 6. CNG Fueling Area at Bladensburg........................................................................ 12

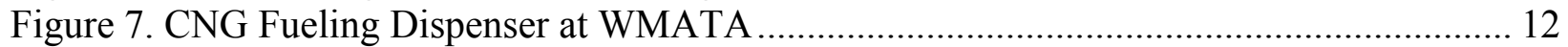

Figure 8. Maintenance Facility at Bladensburg ................................................................ 13

Figure 9. Fuel Economy (mpg) of Diesel Buses at Bladensburg (All Data) ............................. 17

Figure 10. Monthly Fuel Economy (mpDGE) of CNG Buses at Bladensburg (All Data) .......... 18

Figure 11. Monthly and Cumulative Maintenance Cost for Diesel Buses (\$/Mile, All Data)

(for diesel buses, All Data = Evaluation Period) ......................................................... 21

Figure 12. Monthly and Cumulative Maintenance Cost for CWI CNG Buses

(\$/Mile, All Data) ............................................................................................... 22

Figure 13. Monthly and Cumulative Maintenance Cost for Deere CNG Buses

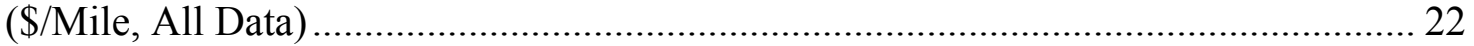

Figure 14. Cumulative MBRC for Diesel Buses (All Data) (for diesel buses, All Data =

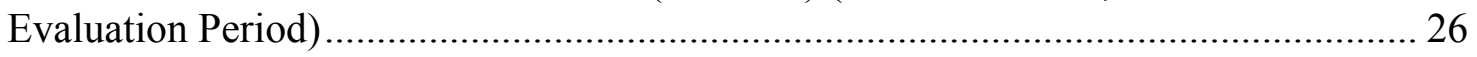

Figure 15. Cumulative MBRC for CNG Buses (All Data) ................................................... 27

\section{List of Tables}

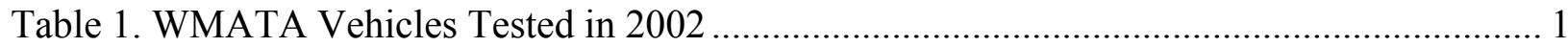

Table 2. CWI C Gas Plus Engine Specifications and Ratings ................................................ 6

Table 3. Specifications and Ratings for Deere 6081H Natural Gas Engine ................................ 7

Table 4. Current Transit Demonstration Sites for the Deere 6081H Natural Gas Engine............. 8

Table 5. Evaluation Buses and Data Periods .................................................................... 8

Table 6. WMATA Diesel and CNG Bus System Description Summary ................................ 10

Table 7. Emissions Certification Levels (g/bhp-hr)......................................................... 11

Table 8. Summary of CNG Bus Operation at Bladensburg.................................................... 14

Table 9. Average Monthly Bus Use (Evaluation Period) .................................................. 15

Table 10. Fuel Consumption and Economy by Vehicle (Evaluation Period) ............................ 16

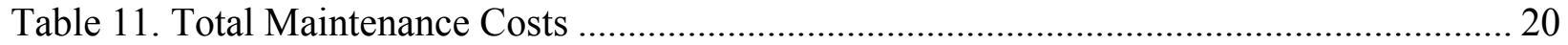

Table 12. Breakdown of Vehicle System Maintenance Costs (Evaluation Periods Only) .......... 24

Table 13. Summary of Roadcalls by System (Evaluation Periods) ....................................... 28

Table 14. Total Operating Cost (\$/Mile, Evaluation Periods) ............................................... 29 


\section{Acronyms and Abbreviations}

$\begin{array}{ll}\text { APTA } & \text { America Public Transportation Association } \\ \text { CO } & \text { carbon monoxide } \\ \text { CNG } & \text { compressed natural gas } \\ \text { CWI } & \text { Cummins Westport, Inc. } \\ \text { DDC } & \text { Detroit Diesel Corporation } \\ \text { DGE } & \text { diesel gallon equivalent } \\ \text { DOE } & \text { U.S. Department of Energy } \\ \text { DPF } & \text { diesel particulate filter } \\ \text { EGR } & \text { exhaust gas recirculation } \\ \text { g/bhp-hr } & \text { grams per brake horsepower hour } \\ \text { hp } & \text { horsepower } \\ \text { HVAC } & \text { heating, ventilation, and air conditioning } \\ \text { MBRC } & \text { miles between roadcall } \\ \text { mpDGE } & \text { miles per diesel gallon equivalent } \\ \text { mpg } & \text { miles per gallon } \\ \text { mph } & \text { miles per hour } \\ \text { NGVTF } & \text { Natural Gas Vehicle Technology Forum } \\ \text { NMHC } & \text { non-methane hydrocarbon } \\ \text { NO } & \text { nitrogen oxide/oxides of nitrogen } \\ \text { NREL } & \text { National Renewable Energy Laboratory } \\ \text { PM } & \text { particulate matter } \\ \text { PMI } & \text { preventive maintenance inspection } \\ \text { ppm } & \text { parts per million } \\ \text { rpm } & \text { revolutions per minute } \\ \text { scf } & \text { standard cubic feet } \\ \text { THC } & \text { total hydrocarbon } \\ \text { TUG } & \text { Natural Gas Transit User's Group } \\ \text { ULSD } & \text { ultra-low sulfur diesel } \\ \text { WMATA } & \text { Washington Metropolitan Transit Authority } \\ & \end{array}$




\section{Executive Summary}

This evaluation of compressed natural gas $(\mathrm{CNG})$ powered transit buses at Washington Metropolitan Area Transit Authority (WMATA) was funded and supported by the U.S. Department of Energy's (DOE) FreedomCAR and Vehicle Technologies Program. The evaluation was completed using a documented data collection and evaluation protocol developed specifically for the assessment of these transportation technologies in operation [1].

The objective of this report is to provide a reasonable comparison between currently available $\mathrm{CNG}$ and standard diesel transit buses. The report includes operational, maintenance, and performance data for each study fleet operating from the same depot. Transit agencies considering use of alternative fuel and advanced propulsion technology transit buses are the primary intended audience for this information.

WMATA has been operating $164 \mathrm{CNG}$ buses since 2002 at its Bladensburg depot. Another 250 CNG buses and another CNG depot (Four Mile Run) began operation in 2005. The evaluation in this report focuses on the first order of CNG buses operating at the Bladensburg depot. Two CNG bus propulsion systems were evaluated: the Cummins Westport, Inc. (CWI) C Gas Plus and the John Deere 6081H.

The results presented focus on the evaluation periods for each study group of buses: diesel buses, 12 months (9/2001-8/2002); CWI CNG buses, 12 months (6/2003-5/2004); Deere CNG buses, 6 months (4/2004-9/2004). The Deere CNG buses had a limited evaluation of 6 months because the implementation was a field test confirmation of the technology, which will be a full market introduction with the next Deere CNG bus order from WMATA. The CWI CNG bus propulsion technology was considered a fully implemented commercial product and had a full 12-month evaluation. Diesel propulsion technology was used as the baseline for this evaluation.

Implementation Experience. WMATA staff were dedicated to a positive implementation of CNG buses and appeared to implement the CNG buses into its operation with ease. Work was done early to ensure the equipment (vehicles and facilities) was well matched to WMATA's operation. Management was reported to have been supportive while allowing depot staff to make their own implementation decisions. Because of all the work done before the buses and equipment were brought to the depot, the overall implementation experience was better than expected. WMATA also received good technical support from manufacturers and others.

Routes and Bus Use. The $\mathrm{CNG}$ and diesel buses at the Bladensburg depot were used randomly on routes with only 40 -foot buses. The CNG buses did not have restrictions due to range or power. The diesel buses (without diesel particulate filters) used in the evaluation operated from Bladensburg depot from 2001-2002 (before the use of the CNG buses). The CNG buses operated from Bladensburg depot starting in 2002.

Fuel Economy and Cost. The CNG buses had fuel economies $16 \%-18 \%$ lower than the diesel buses: $2.3-2.4 \mathrm{mpDGE}$ (miles per diesel gallon equivalent) for the CNG buses versus $2.8 \mathrm{mpg}$ for the diesel buses. This fuel economy difference is better than the $20 \%-25 \%$ fuel economy penalty for CNG shown in previous DOE/National Renewable Energy Laboratory transit bus studies. 
The CNG fuel cost averaged \$1.19/DGE (diesel energy gallon equivalents) during the evaluation period. Adding the electricity cost for the CNG compressor station (\$0.14/DGE), the total CNG fuel cost was \$1.33/DGE. The ultra-low sulfur diesel (ULSD) fuel cost during the evaluation period for the diesel bus operation at Bladensburg (2002) averaged \$0.75/gal. However, during the CNG bus evaluation period, the ULSD fuel cost averaged \$1.33/gal.

Total Maintenance Costs. For the evaluation periods, the CWI CNG buses had 12\% lower total maintenance costs than the diesel buses, and the Deere CNG buses had 2\% lower total maintenance costs than the diesel buses.

Engine- and Fuel-Related Maintenance Costs. The engine- and fuel-related systems are the air intake, cooling, exhaust, fuel, engine, and non-lighting electrical (cranking, charging, and ignition) systems. These vehicle systems are the most relevant when comparing the differences in diesel and CNG transit bus propulsion technologies. The CWI CNG buses had costs $11 \%$ higher than the diesel buses, and the Deere CNG buses had costs 3\% higher than the diesel buses. The higher maintenance cost for the CNG buses versus the diesel buses for these systems was expected because of higher-cost engine oil, fuel filters, and the addition of the spark plugs and ignition systems for the CNG buses.

Roadcalls. A roadcall is defined in this report as an on-road failure of an in-service bus requiring the bus to be taken out of service or replaced on route. Both CNG bus groups had better miles between roadcall (MBRC) rates than the diesel buses. The CWI CNG buses had an all roadcall MBRC 44\% higher and engine- and fuel-related roadcall MBRC 41\% higher than the diesel buses. The Deere CNG buses had an all roadcall MBRC 58\% higher and engine- and fuel-related roadcall MBRC 16\% higher than the diesel buses.

Total Operating Costs. The total operating costs for the study buses were similar. The fuel costs for $\mathrm{CNG}$ and diesel during the $\mathrm{CNG}$ bus evaluation periods were the same at $\$ 1.33 / \mathrm{DGE}$. The total operating costs were as follows: diesel, $\$ 1.06 /$ mile; CWI CNG, $\$ 1.09 /$ mile; and Deere CNG, $\$ 1.14 /$ mile. The major contributing factors are the fuel costs and fuel economy. Significant changes in the fuel cost or fuel economy would change total operating costs significantly.

Future Bus Orders at WMATA. A subsequent CNG bus order consisted of $250 \mathrm{CNG}$ buses from Orion (model VII, low floor), delivered in 2005. Another CNG bus facility came online in 2005. After this $250 \mathrm{CNG}$ bus order, the next bus order is planned to be diesel and diesel hybrid buses. These diesel buses are required at WMATA to lower the average diesel bus age at the eight depots not currently operating CNG buses.

Status of the CNG Bus Propulsion Technologies. The CWI CNG bus propulsion technology appears from the evaluation to be a mature technology, and is similar in operation and cost to the diesel bus technology. The Deere CNG bus propulsion technology was a field test confirmation during this project and only underwent a limited evaluation. However, by the end of the evaluation, the results indicated that this propulsion technology was maturing. WMATA and Deere have agreed to implement another 100 Deere CNG buses as part of WMATA's 250 CNG bus order in 2005; this will be the first full market introduction of the Deere CNG bus propulsion technology. The order indicates WMATA's confidence in the Deere technology. 


\section{Introduction}

This evaluation of compressed natural gas $(\mathrm{CNG})$ transit buses at Washington Metropolitan Area Transit Authority (WMATA) was supported by the U.S. Department of Energy's (DOE) FreedomCAR and Vehicle Technologies Program. The National Renewable Energy Laboratory (NREL) managed the evaluation as part of DOE's Natural Gas Vehicle Technology Forum $(\mathrm{NGVTF})^{1}$. DOE and NREL have supported the development and deployment of advanced propulsion and alternative fuel vehicles in the United States for many years. The evaluation presented in this report was completed using a documented data collection and evaluation protocol developed specifically for the assessment of advanced propulsion and alternative fuel transportation technologies in operation [1].

This evaluation, conducted in 2004, follows a previous study of WMATA transit buses. In 2002, NREL, West Virginia University, and WMATA conducted a short test program comparing the emissions of WMATA's Cummins Westport, Inc. (CWI) CNG buses and Detroit Diesel Corporation (DDC) Series 50 diesel buses. Table 1 and Figure 1 summarize the vehicle specifications and results that were published [2]. These buses had the same configuration as the CWI and DDC buses examined in the present evaluation but were not the identical buses.

Table 1. WMATA Vehicles Tested in 2002

\begin{tabular}{|l|c|c|}
\hline & CNG Buses & Diesel Buses \\
\hline Manufacturer & New Flyer & Orion \\
\hline Model year & 2001 & 2000 \\
\hline GVWR (Ib) & 40,600 & 42,540 \\
\hline Odometer (mi) & 1,900 & 2,290 \\
& 2,400 & 5,000 \\
& 2,500 & 105,000 \\
& 2,600 & 112,900 \\
\hline Engine & 2,600 & \\
\hline Displacement (L) & CWI C Gas Plus & DDC Series 50 \\
\hline Rated power (hp) & 2.3 & 8.5 \\
\hline
\end{tabular}

${ }^{1}$ See the NGVTF Web site at www.nrel.gov/vehiclesandfuels/ngvtf. 


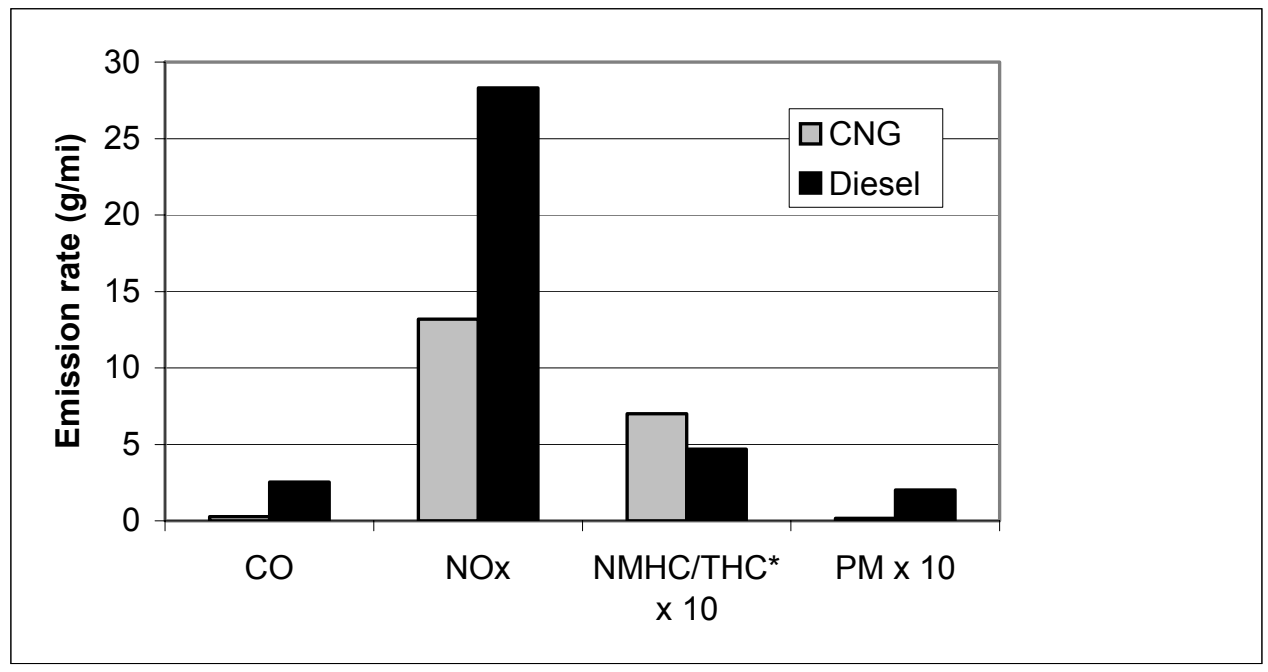

*NMHC for CNG buses, THC for diesel buses.

Figure 1. Results of 2002 WMATA Emission Testing, Central Business District Cycle

The 2004 evaluation described in this report was designed to provide a more complete picture of WMATA's CNG (Figure 2) and diesel buses, comparing in-service operation of the vehicles. The objective was to provide a reasonable comparison between currently available CNG and diesel transit buses. WMATA was chosen for participation in the project based on the agency's dedication to making the $\mathrm{CNG}$ technology work in transit service, its commitment to future $\mathrm{CNG}$ transit bus orders, and its conversion of another depot to CNG transit bus operations.

The evaluation includes data collected on the operational, maintenance, and performance characteristics of each study fleet operating from the same depot. Additional (to the 2002 testing) emissions testing of similar WMATA CNG and diesel buses were also evaluated; those results are published in another report [3]. Transit agencies considering the use of alternative fuel and advanced propulsion transit buses are the primary intended audience for this information.

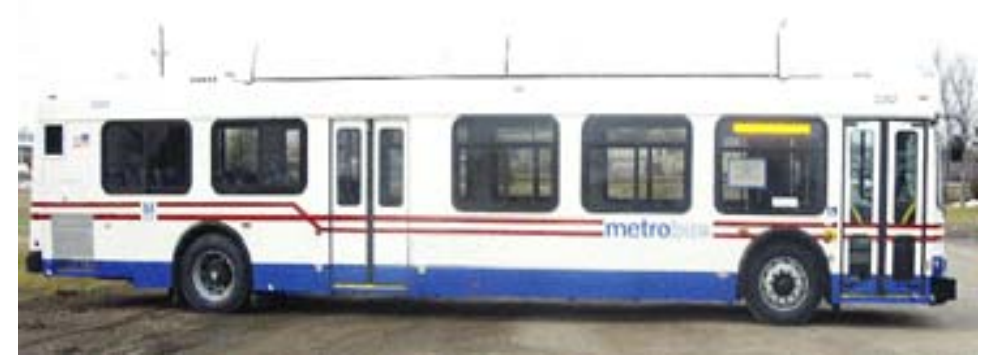

Figure 2. WMATA CNG Transit Bus 


\section{Fleet Profile: Washington Metropolitan Transit Authority}

The American Public Transportation Association (APTA) ranks WMATA as the fourth largest transit system in the United States for combined rail and bus transit, based on passenger miles in fiscal year 2002 [4]. The WMATA service area includes 3.5 million people within a 1,500 square mile area spanning Washington, DC, and parts of Maryland and Virginia (Figure 3). WMATA's 1,460 buses are housed and maintained in 10 depots:

\section{District of Columbia}

- Bladensburg

- Northern

- Southeastern

- Western
Maryland

- Landover

- Montgomery

- Southern Ave
Virginia

- Arlington

- Four Mile Run

- Royal

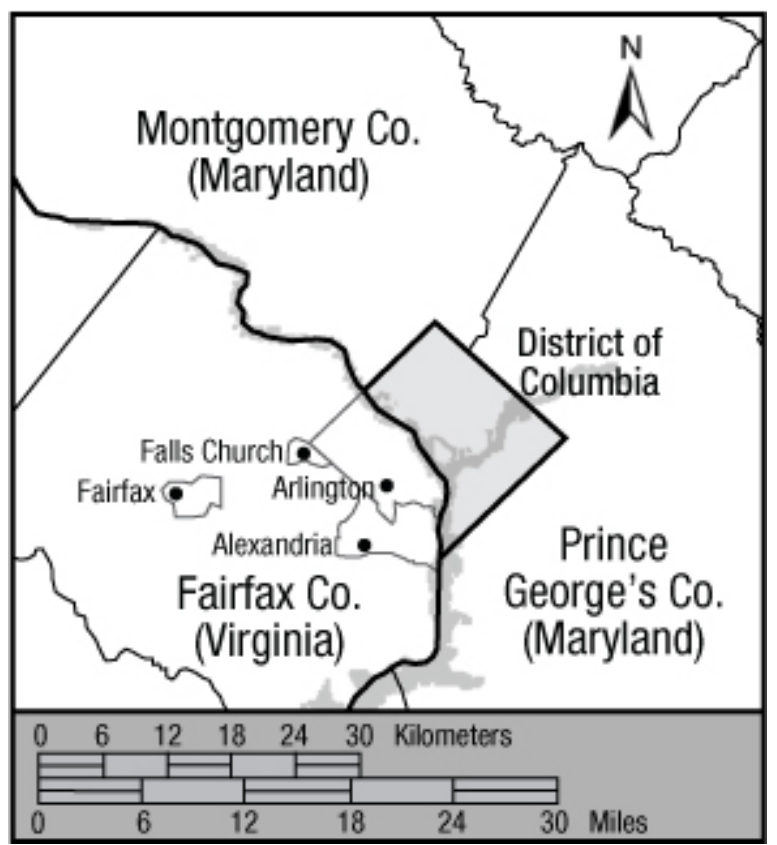

Figure 3. WMATA's Service Area

\section{Emission Reduction Programs}

WMATA is aggressively reducing emissions from its bus fleet. Its strategies include purchasing CNG buses as well as deploying passive regenerative diesel particulate filters (DPFs) on diesel buses and using ultra-low sulfur diesel (ULSD) fuel. As of October 2001, WMATA changed its diesel fuel supply to 100\% ULSD (approximately $15 \mathrm{ppm}$ sulfur), which enables more effective catalysts to be used in conjunction with the DPFs.

WMATA has been up-fitting 515 of its diesel buses with DPFs, which require use of ULSD to most effectively reduce emissions of particulate matter (PM) and hydrocarbons. WMATA replaced the 2-cycle diesel engines in another 59 diesel buses with new 4-cycle diesel engines equipped with exhaust gas recirculation (EGR) to demonstrate current low-emission diesel 
engine technology. WMATA also has supported chassis dynamometer emissions testing to document the emissions of different bus technologies $[2,3]$.

\section{Compressed Natural Gas Bus Program}

WMATA is planning to operate 414 CNG buses by 2006, complete modification of two bus divisions to accommodate CNG buses, and modify the Bladensburg Heavy Maintenance Shop to support CNG bus maintenance. The introduction of CNG buses and facility capabilities at WMATA at the time of the completion of this report was as follows:

\section{CNG Buses}

- $\quad$ Received 100 CNG buses from New Flyer, September 21, 2001

- $\quad$ Put first CNG buses into service, February 2002

- Received 64 CNG buses from New Flyer, mid-2002

- Ordered 250 CNG buses from Orion started delivery in 2005.

\section{CNG Fueling and Maintenance Facilities}

- Completed Bladensburg Bus Division CNG fueling and maintenance facility modifications, September 2002

- Completed Bladensburg Heavy Maintenance Shop modifications, September 2002

- Four Mile Run Bus Division fueling and maintenance facility modifications, completed in 2005.

WMATA intends the Bladensburg and Four Mile Run Bus Divisions to operate only CNG buses, except possibly a few diesel buses for special applications. Both divisions will have a full complement of CNG buses by 2006 with receipt of the 250 Orion VII CNG buses. WMATA determined that two other depots could be considered for CNG conversion; however, capital funding has not been made available. The other six depots are not candidates because of age of the buildings and availability of necessary real estate surrounding the depots.

\section{Future Bus Orders}

Beyond the order of 250 CNG buses, WMATA's next planned acquisitions are "clean diesel" buses (diesel buses with advanced emission control technologies fueled with ULSD) and diesel hybrid electric buses. This diesel bus procurement is being pursued because WMATA needs to infuse new buses into its eight non-CNG bus depots. 


\section{CNG Propulsion Technology}

This section provides general information about the CNG propulsion technologies included in this evaluation at WMATA. As mentioned above, WMATA has 164 full-size CNG transit buses in operation at the Bladensburg bus depot and began receiving 250 more full-size CNG transit buses in 2005. Of the 164 CNG buses, 159 have the CWI C Gas Plus natural gas engine, and five have the John Deere Power Systems 6081H natural gas engine. Originally, all 164 CNG buses had the CWI engine; however, the CWI engine was removed from five of the buses and replaced with the Deere engine before the buses were delivered to the Bladensburg depot. The extra five CWI engines were placed into parts inventory at Bladensburg for later use.

The five buses with Deere natural gas engines were a field test confirmation project at WMATA. The testing resulted in WMATA's next order of 250 CNG buses, including 100 buses with the Deere engine. The other $150 \mathrm{CNG}$ buses will have the CWI engine.

\section{Cummins Westport, Inc.}

CWI is a 50-50 joint venture between Cummins, Inc. and Westport Innovations, Inc. Cummins, headquartered in Columbus, Indiana, is a large manufacturer of diesel engines for all types of applications, including on- and off-road heavy trucks and power generation. Westport Innovations, based in Vancouver, British Columbia, is working to develop new commercial engine products by converting petroleum-based technologies to gaseous fuels. CWI engine products are sold and serviced by the Cummins distributor and dealer network.

Four CWI gaseous fuel engines are currently available in several horsepower settings (latest upgrade introduction shown in parentheses) as follows:

- $\quad$ B Gas Plus, 5.9 liter, natural gas, up to $230 \mathrm{hp}$ (introduced 2002)

- $\quad$ B LPG Plus, 5.9 liter, propane, up to $195 \mathrm{hp}$ (introduced 2003)

- C Gas Plus, 8.3 liter, natural gas, up to $280 \mathrm{hp}$ (introduced 2001)

- L Gas Plus, 8.9 liter, natural gas, up to $320 \mathrm{hp}$ (introduced 2003).

The C Gas Plus (Figure 4) was developed for trucks and buses, and has been a commercial product since 2001. It is used by a number of transit agencies in their buses. Development of the "Plus" version of the engine was supported by DOE and NREL [5,6]. Specifications and available power ratings are shown in Table 2. 


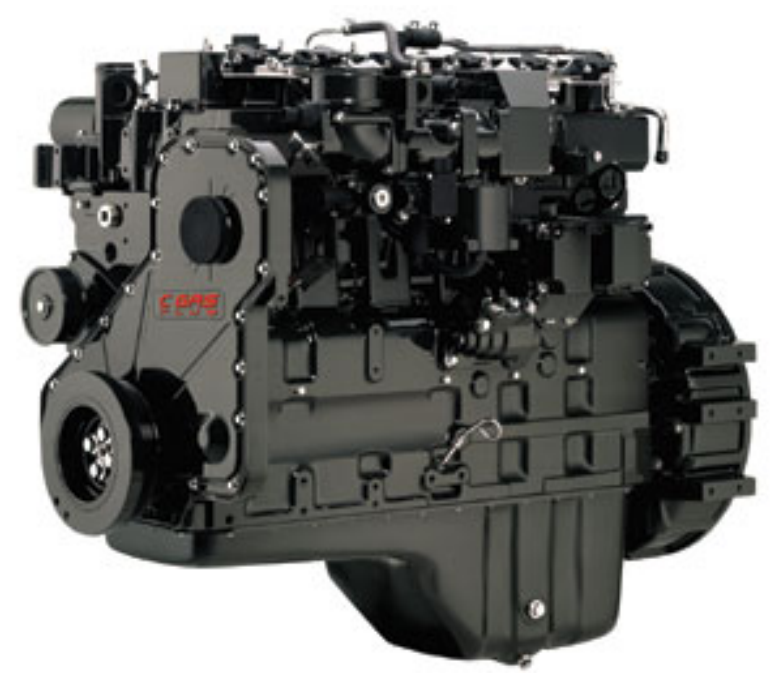

Figure 4. CWI C Gas Plus Engine

Table 2. CWI C Gas Plus Engine Specifications and Ratings

\begin{tabular}{|c|c|c|}
\hline \multicolumn{3}{|l|}{ Specifications } \\
\hline Advertised Power & \multicolumn{2}{|c|}{$250-280 \mathrm{hp}$} \\
\hline Governed Speed & \multicolumn{2}{|c|}{$2,400 \mathrm{rpm}$} \\
\hline Displacement & \multicolumn{2}{|c|}{$8.3 \mathrm{~L}$} \\
\hline Number of Cylinders & \multicolumn{2}{|c|}{6} \\
\hline Compression Ratio & \multicolumn{2}{|c|}{$10: 1$} \\
\hline Oil System Capacity & \multicolumn{2}{|c|}{ 6.3 U.S. gal } \\
\hline Combustion System & \multicolumn{2}{|c|}{ Spark Ignited } \\
\hline Aspiration & \multicolumn{2}{|c|}{ Turbocharged } \\
\hline Net Weight Dry & \multicolumn{2}{|c|}{$1,330 \mathrm{lb}$} \\
\hline Fuel Types & \multicolumn{2}{|c|}{ CNG/LNG, methane number 65 or greater } \\
\hline \multicolumn{3}{|l|}{ Ratings } \\
\hline CG-280 & 280 hp @ 2,400 rpm & 850 lb-ft @ 1,400 rpm \\
\hline CG-275 & 275 hp @ 2,400 rpm & 750 lb-ft @ 1,400 rpm \\
\hline CG-250 & 250 hp @ 2,400 rpm & 750 lb-ft @ 1,400 rpm \\
\hline CG-250 & 250 hp @ 2,400 rpm & 660 lb-ft @ 1,400 rpm \\
\hline
\end{tabular}

Source: CWI Web site, www.cumminswestport.com

\section{John Deere Power Systems}

John Deere Power Systems, based in Waterloo, Iowa, is a manufacturing division of Deere \& Company. John Deere is well known for farming and off-road equipment; however, their products are used in many applications, including an on-highway natural gas engine, model $6081 \mathrm{H}$ (Figure 5). This engine is advertised for use in school buses, shuttle/transit buses, and other on-highway applications. DOE and NREL supported the development and deployment of the $6081 \mathrm{H}$ engine [7]. Specifications and available power ratings are shown in Table 3. 


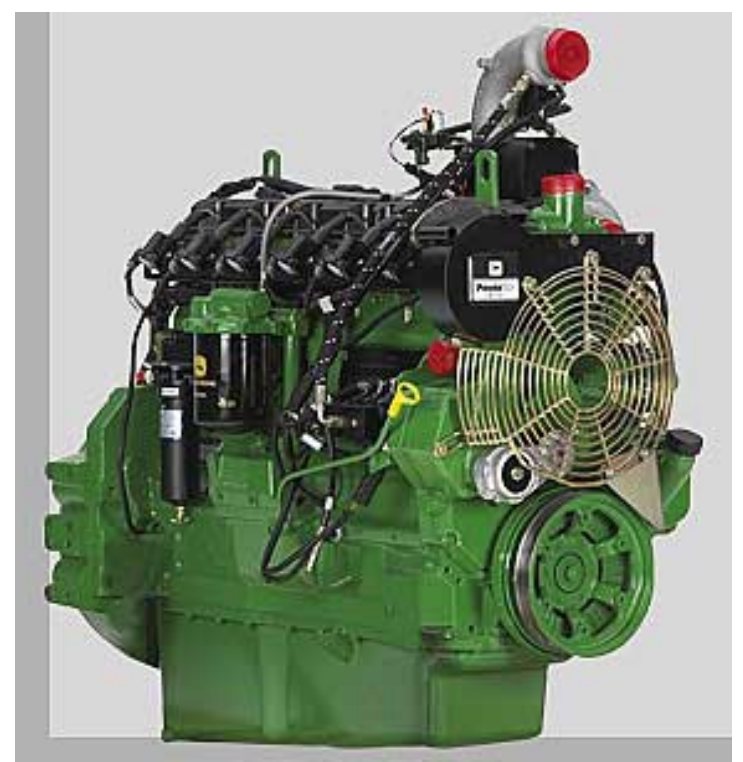

Figure 5. John Deere Power Systems 6081H Natural Gas Engine

Table 3. Specifications and Ratings for Deere 6081H Natural Gas Engine

\begin{tabular}{|c|c|c|}
\hline \multicolumn{3}{|l|}{ Specifications } \\
\hline Model & \multicolumn{2}{|c|}{$6081 \mathrm{H}$} \\
\hline Advertised Horsepower & \multicolumn{2}{|c|}{$250-280 \mathrm{hp}$} \\
\hline Number of Cylinders & \multicolumn{2}{|c|}{6} \\
\hline Displacement & \multicolumn{2}{|c|}{$8.1 \mathrm{~L}$} \\
\hline Compression Ratio & \multicolumn{2}{|c|}{$11: 1$} \\
\hline Combustion System & \multicolumn{2}{|c|}{ Spark Ignited } \\
\hline Aspiration & \multicolumn{2}{|c|}{ Turbocharged } \\
\hline Weight & \multicolumn{2}{|c|}{$1,660 \mathrm{lb}$} \\
\hline Fuel Types & \multicolumn{2}{|c|}{ CNG/LNG } \\
\hline \multicolumn{3}{|l|}{ Ratings } \\
\hline $6081 \mathrm{H} 280 \mathrm{hp}$ & 280 hp @ 2200 rpm & 900 ft-lb @ 1500 rpm \\
\hline $6081 \mathrm{H} 275 \mathrm{hp}$ & 275 hp @ 2200 rpm & 800 ft-lb @ 1400 rpm \\
\hline $6081 \mathrm{H} 250 \mathrm{hp}$ & 250 hp @ 2200 rpm & 800 ft-lb @ 1400 rpm \\
\hline $6081 \mathrm{H} 250 \mathrm{hp}$ & 250 hp @ 2200 rpm & 735 ft-lb @ 1300 rpm \\
\hline
\end{tabular}

Source: John Deere Web site, www.deere.com

Deere has been working to introduce this natural gas engine into the transit bus market. Table 4 shows transit agencies where the engine is being demonstrated. WMATA's order of 100 Deere engines represents the engine's transition beyond the demonstration phase. 
Table 4. Current Transit Demonstration Sites for the Deere 6081H Natural Gas Engine

\begin{tabular}{|l|l|c|}
\hline \multicolumn{1}{|c|}{ Demonstration Site } & \multicolumn{1}{c|}{ Location } & Number of Buses \\
\hline Omnitrans & San Bernardino, CA & 2 \\
\hline MetroLink & Rock Island, IL & 21 \\
\hline WMATA & Washington, DC & 5 \\
\hline $\begin{array}{l}\text { Metropolitan Atlanta Rapid } \\
\text { Transit Authority (MARTA) }\end{array}$ & Atlanta, GA & 2 \\
\hline Queens Surface Transit & New York City, NY & 2 \\
\hline Utah Transit Authority (UTA) & Salt Lake City, UT & 2 \\
\hline \multicolumn{1}{|c|}{ Total } & $\mathbf{3 4}$ \\
\hline
\end{tabular}

\section{Evaluation Results}

This section shows the results of the evaluation of $\mathrm{CNG}$ buses and diesel buses operating from WMATA's Bladensburg depot. The CNG buses with CWI engines were evaluated for 12 months. The CNG buses with Deere engines were not in operation for a full 12 months during the evaluation at WMATA and were evaluated for only 6 months. The study buses and evaluation periods are shown in Table 5.

Table 5. Evaluation Buses and Data Periods

\begin{tabular}{|c|c|c|c|c|}
\hline Group & $\begin{array}{c}\text { Bus } \\
\text { Number }\end{array}$ & $\begin{array}{c}\text { Start Date of } \\
\text { Operation }\end{array}$ & $\begin{array}{c}\text { Fuel Data } \\
\text { Period }\end{array}$ & $\begin{array}{c}\text { Maintenance } \\
\text { Data Period }\end{array}$ \\
\hline \multirow{4}{*}{ Diesel } & 2070 & $8 / 4 / 2000$ & $9 / 01-8 / 02$ & $11 / 01-8 / 02$ \\
\cline { 2 - 5 } & 2071 & $8 / 8 / 2000$ & $9 / 01-8 / 02$ & $11 / 01-8 / 02$ \\
\cline { 2 - 5 } & 2072 & $8 / 2 / 2000$ & $9 / 01-8 / 02$ & $11 / 01-8 / 02$ \\
\cline { 2 - 5 } & 2073 & $8 / 4 / 2000$ & $9 / 01-8 / 02$ & $11 / 01-8 / 02$ \\
\cline { 2 - 5 } & 2074 & $8 / 22 / 2000$ & $9 / 01-8 / 02$ & $11 / 01-8 / 02$ \\
\hline \multirow{4}{*}{ CNG CWI } & 2302 & $8 / 21 / 2002$ & $6 / 03-5 / 04$ & $6 / 03-5 / 04$ \\
\cline { 2 - 5 } & 2303 & $8 / 14 / 2002$ & $6 / 03-5 / 04$ & $6 / 03-5 / 04$ \\
\cline { 2 - 5 } & 2304 & $8 / 27 / 2002$ & $6 / 03-5 / 04$ & $6 / 03-5 / 04$ \\
\cline { 2 - 5 } & 2307 & $8 / 27 / 2002$ & $6 / 03-5 / 04$ & $6 / 03-5 / 04$ \\
\cline { 2 - 5 } & 2309 & $8 / 20 / 2002$ & $6 / 03-5 / 04$ & $6 / 03-5 / 04$ \\
\hline \multirow{4}{*}{ CNG Deere } & 2460 & $2 / 12 / 2003$ & $4 / 04-9 / 04$ & $4 / 04-9 / 04$ \\
\cline { 2 - 5 } & 2461 & $2 / 12 / 2003$ & $4 / 04-9 / 04$ & $4 / 04-9 / 04$ \\
\cline { 2 - 5 } & 2462 & $2 / 6 / 2003$ & $4 / 04-9 / 04$ & $4 / 04-9 / 04$ \\
\cline { 2 - 5 } & 2463 & $1 / 30 / 2003$ & $4 / 04-9 / 04$ & $4 / 04-9 / 04$ \\
\cline { 2 - 5 } & 2464 & $2 / 5 / 2003$ & $4 / 04-9 / 04$ & $4 / 04-9 / 04$ \\
\hline
\end{tabular}

The diesel buses were in operation at the Bladensburg depot just before the arrival and start of operation of the CNG buses. After the CNG buses started operation, the diesel buses were moved to other WMATA depots for operation. The evaluation period for the diesel buses was chosen to match a year's worth of operation at the Bladensburg depot so that the comparison to the CNG buses would be while operating in a similar duty cycle. Data from the Deere CNG buses originally matched the CWI CNG bus data period, but was extended six months of data beyond a software update for emissions and performance in March 2004, and only those six months were provided in the evaluation period as discussed earlier. 
Evaluation results in this section are focused on the data periods indicated. In several cases, data from the start of operation for the buses is used to explore maturation level of the propulsion technologies. When this has been done, the charts indicate where the evaluation data periods are located within the data set. All data presented in this report have been collected from a time frame when the buses were operating from the Bladensburg depot.

\section{Vehicle System Descriptions}

Table 6 shows summary system descriptions for the evaluation buses. Appendix A gives more detailed vehicle system descriptions. The diesel buses were approximately 1 year older than the CNG buses and built by a different manufacturer. These differences are expected to affect the evaluation and are discussed in the data evaluation section of this report. 
Table 7 shows emissions certification levels for the engines studied in this evaluation. Both groups of buses with CNG engines used oxidation catalysts for emissions control. The oxidation catalysts on the Deere engines were upgraded in March 2004; chassis dynamometer emission testing took place in April 2004, after which the 6-month evaluation of the Deere CNG buses began. The CWI CNG buses had the same oxidation catalyst configuration during the evaluation period and emission testing as they had since beginning operation at WMATA. The diesel buses did not have aftertreatment during the evaluation but had DPFs during the emission testing.

Table 6. WMATA Diesel and CNG Bus System Description Summary

\begin{tabular}{|l|c|c|c|}
\hline \multicolumn{1}{|c|}{ Vehicle Information } & Diesel & CNG - CWI & CNG - Deere \\
\hline Number of Buses in Study & 5 & 5 & 5 \\
\hline $\begin{array}{l}\text { Chassis } \\
\text { Manufacturer/Model }\end{array}$ & $\begin{array}{c}\text { Orion VI Low Floor } \\
(06.501)\end{array}$ & $\begin{array}{c}\text { New Flyer C40 Low } \\
\text { Floor }\end{array}$ & $\begin{array}{c}\text { New Flyer C40 Low } \\
\text { Floor }\end{array}$ \\
\hline Chassis Model Year & 2000 & 2001 & 2002 \\
\hline Engine Manufacturer/Model & DDC Series 50 & CWI C Gas Plus & Deere 6081H \\
\hline Engine Model Year & 2000 & 2001 & $2002 / 2004^{*}$ \\
\hline Aftertreatment & None & $\begin{array}{c}\text { Fleetguard-Nelson } \\
\text { oxidation catalyst }\end{array}$ & $\begin{array}{c}\text { Johnson Matthey } \\
\text { oxidation catalyst }\end{array}$ \\
\hline $\begin{array}{l}\text { Maximum Power } \\
\text { Maximum Torque }\end{array}$ & $\begin{array}{c}275 \mathrm{hp} @ 2,100 \mathrm{rpm} \\
890 \mathrm{lb}-\mathrm{ft} @ 1,200 \mathrm{rpm}\end{array}$ & $\begin{array}{c}280 \mathrm{hp} \mathrm{@} \mathrm{2,400} \mathrm{rpm} \\
850 \mathrm{lb}-\mathrm{ft} @ 1,400 \mathrm{rpm}\end{array}$ & $\begin{array}{c}280 \mathrm{hp} \mathrm{@} \mathrm{2,200} \mathrm{rpm} \\
900 \mathrm{lb}-\mathrm{ft} @ 1,500 \mathrm{rpm}\end{array}$ \\
\hline Fuel System Capacity & $125 \mathrm{gal}$ & $21,161 \mathrm{scf} @ 3,600 \mathrm{psi}$ & $21,161 \mathrm{scf} @ 3,600 \mathrm{psi}$ \\
\hline $\begin{array}{l}\text { Transmission } \\
\text { Manufacturer/Model }\end{array}$ & Allison/B400R & Allison/B400R & Allison/B400R \\
\hline Curb Weight & $29,300 \mathrm{lb}$ & $30,080 \mathrm{lb}$ & $30,080 \mathrm{lb}$ \\
\hline Gross Vehicle Weight & $42,540 \mathrm{lb}$ & $40,600 \mathrm{lb}$ & $40,600 \mathrm{lb}$ \\
\hline Bus Cost & $\$ 300,000$ & $\$ 340,000$ & $\$ 340,000$ \\
\hline
\end{tabular}

*MY 2002 engines modified to MY 2004 specifications. 
Table 7. Emissions Certification Levels (g/bhp-hr)

\begin{tabular}{|l|l|c|c|c|c|c|c|}
\hline \multicolumn{1}{|c|}{ Model Year } & \multicolumn{1}{|c|}{ Fuel } & THC & NMHC & NO $_{\mathbf{x}}$ & $\mathbf{C O}$ & PM & Engine Family \\
\hline $1998 / 2001$ & Certification Levels & 1.3 & 1.2 & 4.0 & 15.5 & 0.05 & All \\
\hline 2000 Series 50 & Diesel & 0.11 & & 3.9 & 0.9 & 0.05 & YDDXH08.5FJN \\
\hline $2001 / 2$ C Gas Plus & Natural Gas & & 0.2 & 1.5 & 1.3 & 0.01 & 2CEXH0505CBH \\
\hline 2004 & Certification Levels & 1.3 & \multicolumn{2}{|c|}{$2.4,2.5$} & 15.5 & 0.05 & All \\
\hline $20046081 \mathrm{H}$ & Natural Gas & & 0.2 & 1.5 & 0.9 & 0.01 & 4JDXH08.1066 \\
\hline
\end{tabular}

\section{Implementation Experience}

As WMATA was planning to purchase new buses to be delivered in 2000 and 2001, the WMATA Board of Directors expressed a desire to proactively minimize bus emissions in the Washington, DC, metropolitan area. Nitrogen oxide $\left(\mathrm{NO}_{\mathrm{x}}\right)$ was considered the most important emission, followed by PM. The Board requested that WMATA hold a workshop to review available bus technologies so that an informed purchasing decision could be made. WMATA held an alternative fuels workshop in July 2000. Topics included air pollution, asthma, methods of reducing diesel emissions, experience with hybrid electric and $\mathrm{CNG}$ buses, and development of fuel cells. WMATA wanted to reduce emissions as much as possible while using only proven and reliable technology.

One of the conclusions from the workshop was that several technologies could reduce $\mathrm{NO}_{\mathrm{x}}$ well below current diesel emissions levels. Fuel cell technology was preferred for the future but was not expected to be available in the near term. Hybrid electric vehicles were in the testing phase and were not yet proven. Diesel buses with advanced emissions control required ULSD and were expected to reduce most pollutants significantly. CNG buses were the proven technology that produced the lowest $\mathrm{NO}_{\mathrm{x}}$ emissions.

Following the workshop, the Board approved a request for proposal for CNG buses in December 2000, and then approved purchase of 164 low-floor CNG buses from New Flyer in August 2001. To execute the purchase as quickly as possible, WMATA used an existing option on a Pierce Transit (Tacoma, Washington) contract with New Flyer. At about the same time, WMATA reviewed its 10 bus-operating divisions to determine which locations would best accommodate CNG bus operations. Only four of the 10 divisions were candidates for conversion based on age of the buildings and property available for $\mathrm{CNG}$ equipment. The depot chosen to be first to operate CNG buses was Bladensburg. The second depot chosen for CNG operation was Four Mile Run. CNG operations started at Four Mile Run depot in 2005.

Operations at Bladensburg were scheduled to commence in January 2002. This required that a CNG fueling station be constructed, and a 40-year-old maintenance and operating facility be modified. Initial costs included a $\$ 40,000$ incremental increase for the $\mathrm{CNG}$ buses, an additional $\$ 15.6$ million for the fueling facility ( $\sim 4$ million), and modifications to the Bladensburg facility ( $\$ 11.6$ million).

The CNG fueling station at Bladensburg was completed in late 2001 (Figure 6 and Figure 7). CNG fueling, which is provided by three compressors, is located alongside diesel fueling. WMATA pays a contractor approximately $\$ 360,000$ per year for operations and maintenance of the CNG fueling facility and equipment. 
The maintenance facility was modified to accommodate $\mathrm{CNG}$ operation inside the facility, including additional ventilation (4 air changes per hour), methane detection, and alarm systems. Upgrades were required for the lighting and electrical systems. A new heating system was added so there were no open flames. Structural modifications were made for fireproofing and to isolate occupied building areas (office space). These modifications required asbestos disposal from the facility, which was unexpected and added nearly $\$ 1$ million to the cost. Modifications were completed in late 2001. Figure 8 shows the maintenance facility, which is adjacent to the CNG fueling area.

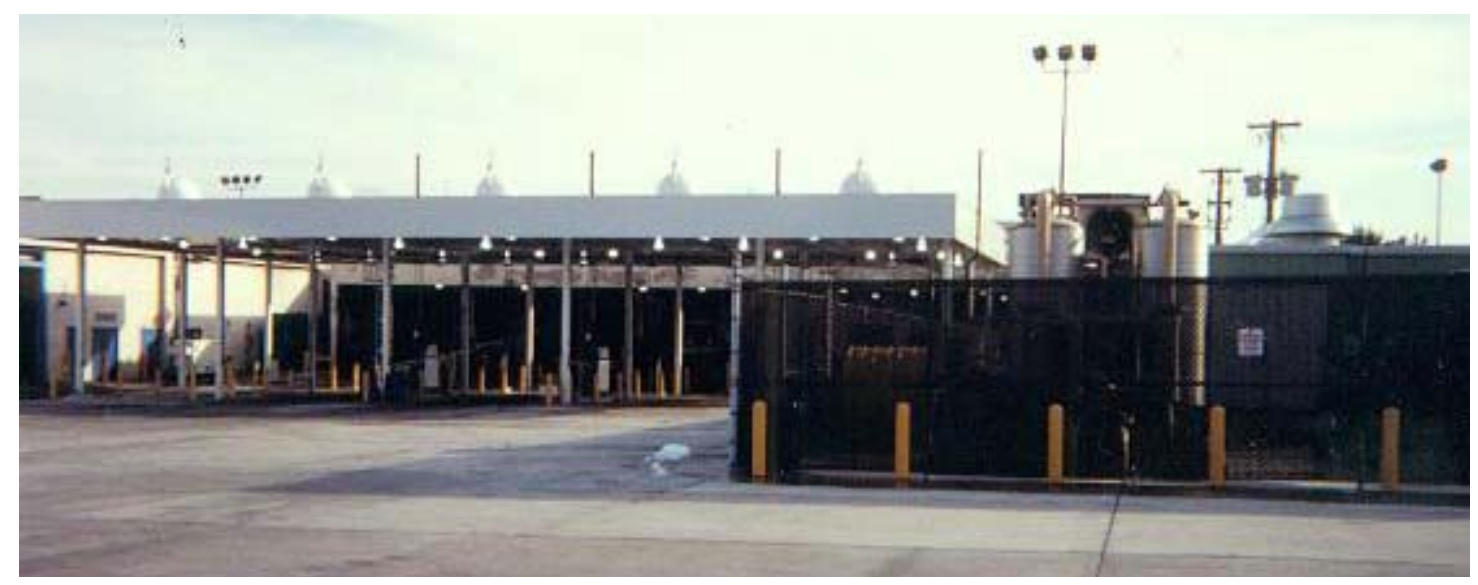

Figure 6. CNG Fueling Area at Bladensburg

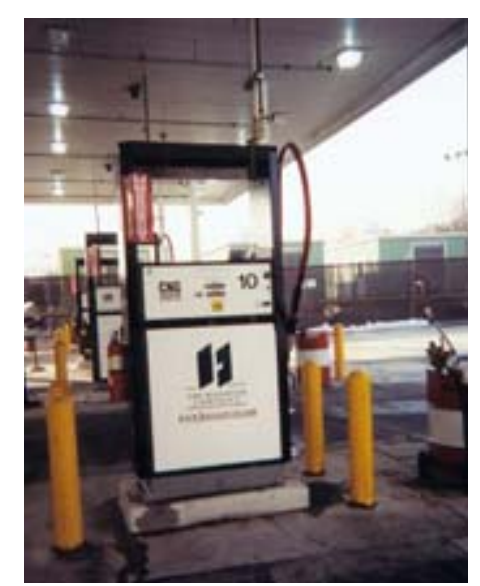

Figure 7. CNG Fueling Dispenser at WMATA

Complete awareness training was a key to successful introduction of the CNG buses, according to WMATA. Management and key staff visited several other transit agencies that had CNG buses in service. Pierce Transit provided training for mechanics and management personnel. WMATA staff also received training from New Flyer and received familiarization training sponsored by DOE and DOE's Clean Cities Program. WMATA participated in the Natural Gas Transit User's Group (TUG) ${ }^{2}$ and hosted one of its meetings. The TUG brings natural gas transit bus operators together to share successes and important natural gas vehicle related information [8].

\footnotetext{
${ }^{2}$ See the NGVTF Web site at www.nrel.gov/vehiclesandfuels/ngvtf/tug.html for more information about TUG.
} 


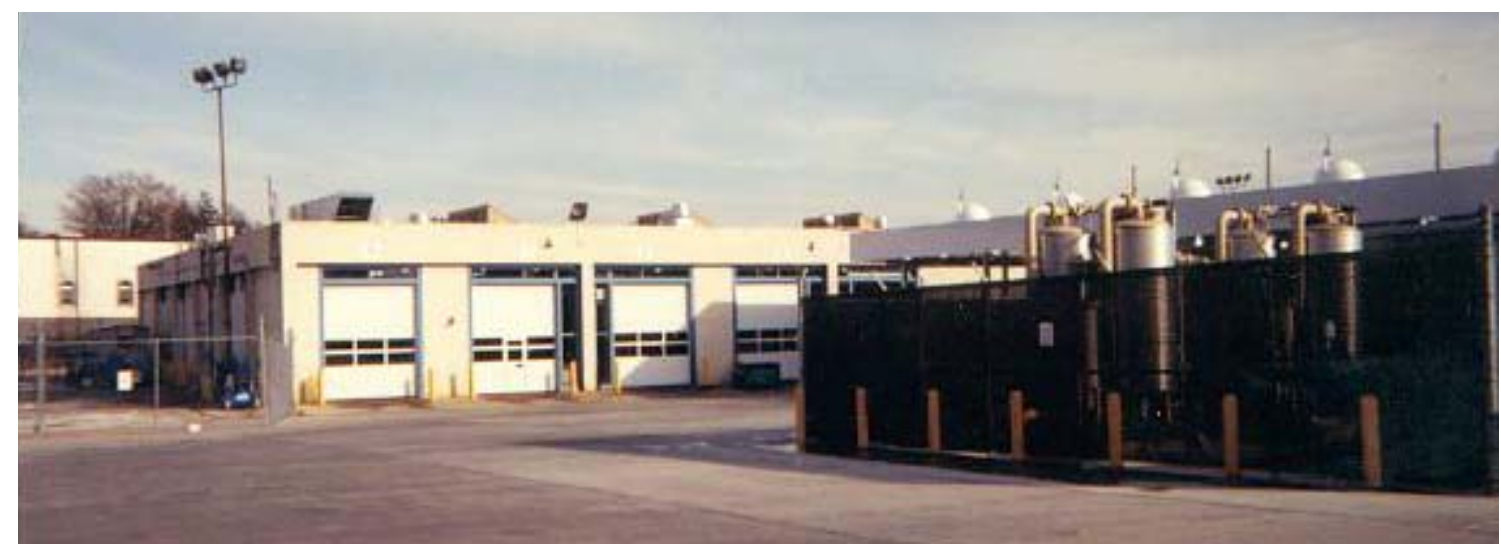

Figure 8. Maintenance Facility at Bladensburg

Many partners contributed to the implementation of CNG buses at WMATA. The following are summarized comments from WMATA staff about the major partners:

- The natural gas company was helpful and responsive to fuel supply and safety issues.

- The fire department became involved early in the process. This was considered a lesson learned, i.e., it is a good idea to involve the fire department early and regularly.

- The permitting process was challenging. There were issues getting all of the parties that needed to sign-off involved.

- WMATA management was supportive and hands-off except when necessary, as reported by staff at Bladensburg. Management was patient with problems that arose.

- DOE/NREL provided technical advice and Clean Cities Tiger Team consultants for advice in technology selection, procurement specifications, and training materials.

- New Flyer, CWI, and Deere were extremely supportive and available to ensure that bus issues were resolved quickly.

WMATA introduced CNG buses starting in February 2002 with 10 buses. All 164 CNG buses were phased into operation by the end of 2003. Comments from WMATA personnel on the implementation process for the fueling station, maintenance and operations facility upgrades; and bus operations were generally positive. The following are summarized comments from WMATA staff about each part of the implementation:

\section{General Comments}

- Lots of work was done well before the buses arrived onsite.

- There were some fears at the beginning, but the training and familiarization information was helpful.

- The slow introduction of the CNG buses into service was a good thing; buses performed better than expected, and reliability was feared to be a much bigger issue than it was.

- Use of CNG was ultimately a good thing: emissions are better, smell is much better, buses are quieter, and the shop is cleaner. The only issue is the fuel economy, but buses have plenty of power.

- The CNG buses were well received by the public. Drivers and mechanics generally like the buses. 
- It was extremely important that WMATA management gave Bladensburg staff the power to make decisions, and that management was patient and supportive.

- It was important to stay on top of the CNG program and be proactive to ensure success.

- Care must be taken not to give in to the temptation to cut corners on the cost of the project and the equipment needed to be successful.

\section{CNG Fueling Station}

- There are no other CNG fueling stations around Bladensburg, so it is extremely important that the fueling station is operational.

- During the blackout in the Northeast, it became clear that Bladensburg should have backup generators for the fueling station, so that fueling can continue even without grid power. (Note: addition of backup power at WMATA is complete.)

\section{Maintenance Facility}

- There were general issues with the methane detection system, specifically false positives; this has been a problem with the fueling station as well. (Note: repair of this system is complete.)

- The need for welding outlets was an issue in the maintenance facility.

\section{Routes and Bus Use}

Currently, the 164 CNG buses are operated from the Bladensburg depot, located at $225026^{\text {th }}$ Street, NE in Washington, DC. The Bladensburg depot operates 232 buses total. All buses of each type/size are randomly dispatched on the routes of that type/size serviced from the depot. The CNG buses do not have restrictions due to range or power requirements. The CNG and diesel buses are interchangeable on all routes that use 40-foot buses. As WMATA receives its next CNG bus order, Bladensburg is expected to receive 38 more CNG buses, for a total of 202 CNG buses out of 232 buses at the depot. The remaining 30 buses at Bladensburg will include articulated buses and buses less than 40 -feet long.

Table 8 shows total mileage and operating hours for CNG buses at Bladensburg; Appendix B gives more detail. The mileage and operating hours include revenue and non-revenue operation. These statistics were calculated to understand the average speed of CNG bus operation as an indicator of duty cycle. The "Total" line in the table includes the weekday numbers multiplied by five, and added to the Saturday and Sunday numbers to give a result for the entire week's operation. The average speed by route ranges from $8-16 \mathrm{mph}$ and is an overall average of 11.6 mph.

Table 8. Summary of CNG Bus Operation at Bladensburg

\begin{tabular}{|l|c|c|c|}
\hline $\begin{array}{c}\text { Day of } \\
\text { Week }\end{array}$ & Miles/Day & $\begin{array}{c}\text { Operating } \\
\text { Hours }\end{array}$ & $\begin{array}{c}\text { Average Speed } \\
\text { (mph) }\end{array}$ \\
\hline Weekday & $16,613.88$ & $1,448.43$ & 11.5 \\
\hline Saturday & $7,224.11$ & 581.73 & 12.4 \\
\hline Sunday & $5,770.27$ & 438.40 & 13.2 \\
\hline Total & $\mathbf{9 6 , 0 6 3 . 7 8}$ & $\mathbf{8 , 2 6 2 . 3 0}$ & $\mathbf{1 1 . 6}$ \\
\hline
\end{tabular}


Table 9 shows average monthly mileage for the study buses. The diesel buses averaged 25\% higher monthly mileage than the CNG buses. The primary reason for this difference between diesel and CNG bus mileage is the way the buses were scheduled during their evaluation periods. The maximum pullout for Bladensburg is 206 buses for the morning peak and 183 buses for the afternoon peak. Only 82 Bladensburg buses pull out in the morning and run all day, and it is these all-day buses that accumulate the highest mileage. When the diesel bus evaluation period began in September 2001, there were no CNG buses at Bladensburg, and the evaluation diesel buses were among the newest diesel buses at the depot. WMATA chose to put the newest diesel buses (including the evaluation buses) on the all-day routes more often than older diesel buses. When the CNG buses began operation at Bladensburg they were more randomly assigned to the all-day routes, i.e., unlike the diesel evaluation buses, the CNG evaluation buses were not preferentially used on all-day routes. Thus, the CNG evaluation buses averaged less monthly and yearly mileage than the diesel evaluation buses. WMATA indicated that the difference in mileage per vehicle was not because of a problem with the CNG buses.

Only 6 months of data for the Deere CNG buses are included in this analysis (Table 5). Deere was still having maintenance and operating issues with bus number 2464 (discussed later) during the evaluation, which kept that bus from reaching a monthly average mileage close to the other buses.

Table 9. Average Monthly Bus Use (Evaluation Period)

\begin{tabular}{|l|c|c|c|}
\hline Vehicle & Total Mileage & Months & Monthly Average \\
\hline 2070 & 34,399 & 12 & 2,867 \\
\hline 2071 & 39,361 & 12 & 3,280 \\
\hline 2072 & 45,252 & 12 & 3,771 \\
\hline 2073 & 34,894 & 12 & 2,908 \\
\hline 2074 & 31,539 & 11 & 2,867 \\
\hline Diesel Buses & $\mathbf{1 8 5 , 4 4 5}$ & $\mathbf{5 9}$ & $\mathbf{3 , 1 4 3}$ \\
\hline 2302 & 23,842 & 11 & 2,167 \\
\hline 2303 & 36,951 & 12 & 3,079 \\
\hline 2304 & 29,710 & 12 & 2,476 \\
\hline 2307 & 29,436 & 12 & 2,453 \\
\hline 2309 & 23,769 & 10 & 2,377 \\
\hline CNG Buses - CWI & $\mathbf{1 4 3 , 7 0 8}$ & $\mathbf{5 7}$ & $\mathbf{2 , 5 2 1}$ \\
\hline 2460 & 14,773 & 6 & 2,462 \\
\hline 2461 & 16,162 & 6 & 2,694 \\
\hline 2462 & 16,914 & 6 & 2,819 \\
\hline 2463 & 16,619 & 6 & 2,770 \\
\hline 2464 & 9,035 & 6 & 1,506 \\
\hline CNG Buses - Deere & $\mathbf{7 3 , 5 0 3}$ & $\mathbf{3 0}$ & $\mathbf{2 , 4 5 0}$ \\
\hline
\end{tabular}




\section{Fuel Consumption, Economy, and Cost}

Data for fuel consumption included each fuel fill (amount of fuel, hubodometer reading, and date), and fuel prices were collected from WMATA monthly. Fuel consumption and economy by vehicle and study group are detailed in Appendix C. WMATA used \#2 diesel until it switched to ULSD in October 2001.

The CNG fuel consumption data were collected at the CNG dispenser with a readout in diesel energy gallon equivalents (DGE). The dispenser actually measures $\mathrm{CNG}$ in pounds mass with a Coriolis meter. The dispenser computer converts the pounds mass to DGE at $6.4 \mathrm{lb}$ CNG/DGE.

Table 10 shows fuel consumption and economy for each study vehicle and study group. The diesel bus fuel consumption and economy were calculated from operation during September 2001 through August 2002. The CNG bus fuel consumption and economy for the CWI buses were calculated from operation during June 2003 through May 2004, and for the Deere buses from operation during April 2004 through September 2004.

Table 10. Fuel Consumption and Economy by Vehicle (Evaluation Period)

\begin{tabular}{|l|c|c|c|}
\hline \multicolumn{1}{|c|}{ Vehicle } & $\begin{array}{c}\text { Mileage } \\
\text { (Fuel Base) }\end{array}$ & $\begin{array}{c}\text { Gallons } \\
\text { Consumed }\end{array}$ & MPG* $^{*}$ \\
\hline 2070 & 32,861 & 11,969 & 2.75 \\
\hline 2071 & 36,670 & 12,157 & 3.02 \\
\hline 2072 & 44,515 & 15,076 & 2.95 \\
\hline 2073 & 32,875 & 11,791 & 2.79 \\
\hline 2074 & 31,440 & 11,919 & 2.64 \\
\hline Total - Diesel & $\mathbf{1 7 8 , 3 6 1}$ & $\mathbf{6 2 , 9 1 2}$ & $\mathbf{2 . 8 4}$ \\
\hline 2302 & 23,842 & 9,932 & 2.40 \\
\hline 2303 & 34,650 & 13,593 & 2.55 \\
\hline 2304 & 29,472 & 13,363 & 2.21 \\
\hline 2307 & 29,096 & 12,794 & 2.27 \\
\hline 2309 & 23,769 & 11,140 & 2.13 \\
\hline Total - CNG CWI & $\mathbf{1 4 0 , 8 2 9}$ & $\mathbf{6 0 , 8 2 2}$ & $\mathbf{2 . 3 2}$ \\
\hline 2460 & 14,773 & 6,389 & 2.31 \\
\hline 2461 & 16,162 & 7,208 & 2.24 \\
\hline 2462 & 16,514 & 6,404 & 2.58 \\
\hline 2463 & 15,541 & 6,470 & 2.40 \\
\hline 2464 & 8,803 & 3,628 & 2.43 \\
\hline Total - CNG Deere & $\mathbf{7 1 , 7 9 3}$ & $\mathbf{3 0 , 0 9 9}$ & $\mathbf{2 . 3 9}$ \\
\hline
\end{tabular}

*Miles per diesel gallon for diesel buses, miles per DGE for CNG buses.

The mileage shown in Table 10 is not the entire mileage that each vehicle accumulated during the evaluation period. It is only the mileage used in the fuel economy calculation. Some data have been removed from the fuel economy calculation based on fuel consumption data that was missing from WMATA's data recording system. 
One issue with the fuel economy data is that when the hubodometer reading from WMATA's buses is not available or appears to be incorrect, the computer system inserts a hubodometer reading calculated to match a 3.00-mpg fuel economy. In most cases, this is corrected in the next fuel record in the database. However, in some cases, these incorrect hubodometer readings continue to be recorded for several days or weeks. This causes some of the fuel economy calculations to be artificially high until the hubodometer is corrected in the system.

The energy equivalent fuel economy of the CWI CNG buses was $18 \%$ lower, and the energy equivalent fuel economy of the Deere CNG buses was $16 \%$ lower compared with the diesel buses. This fuel economy difference is better than previous DOE/NREL studies of CNG and LNG transit buses, which showed natural gas bus fuel economy to be $20 \%-30 \%$ lower than diesel bus fuel economy [9,10]. Figure 9 and Figure 10 show fuel economy by study group and month for the diesel and CNG buses during their entire operation at Bladensburg. The diesel buses operated at Bladensburg for more than 2 years and consistently averaged around $2.8 \mathrm{mpg}$. The CNG buses operated since August 2002 and consistently averaged around 2.3-2.4 mpDGE (miles per diesel gallon equivalent).

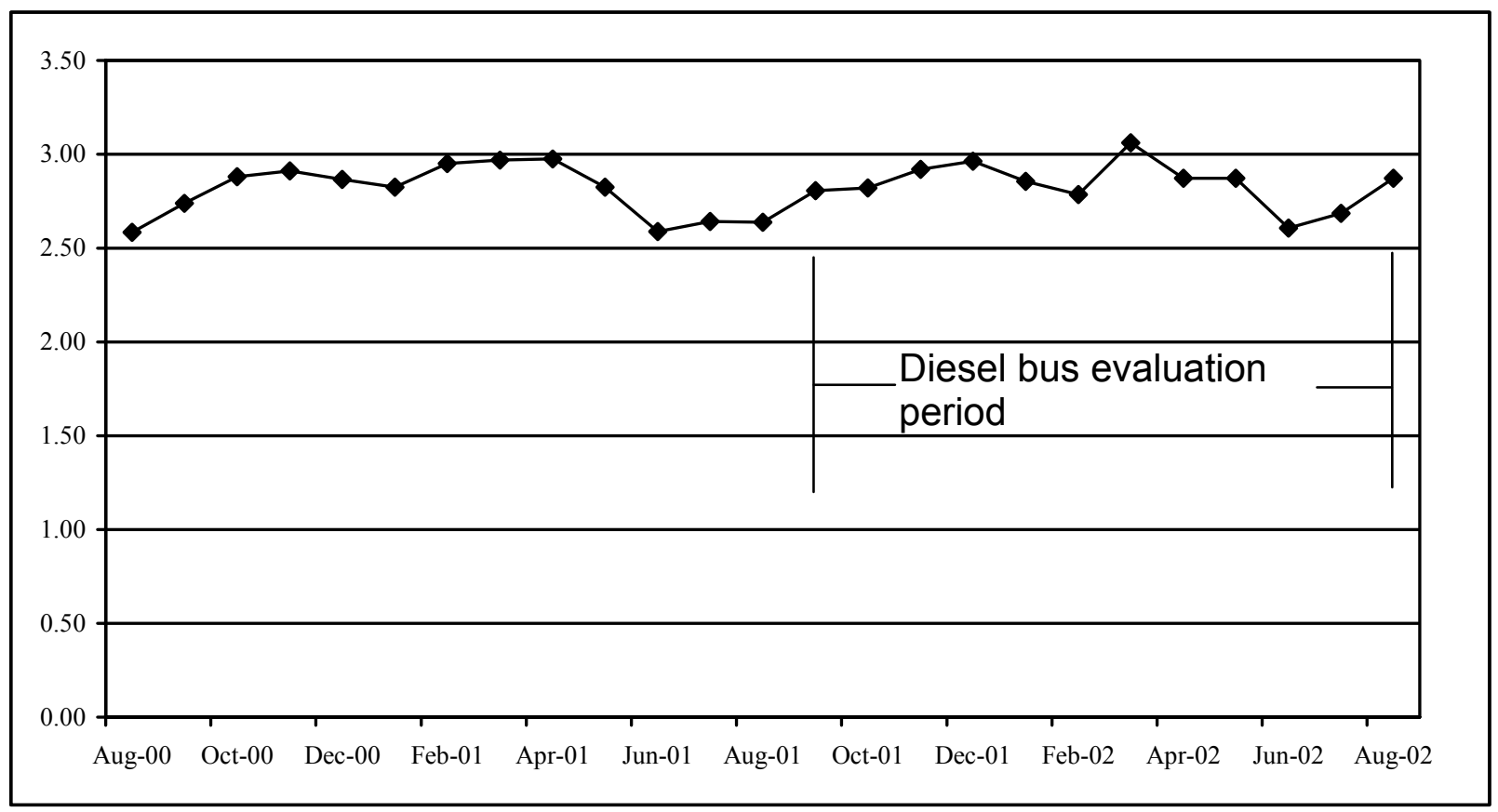

Figure 9. Fuel Economy (mpg) of Diesel Buses at Bladensburg (All Data) 


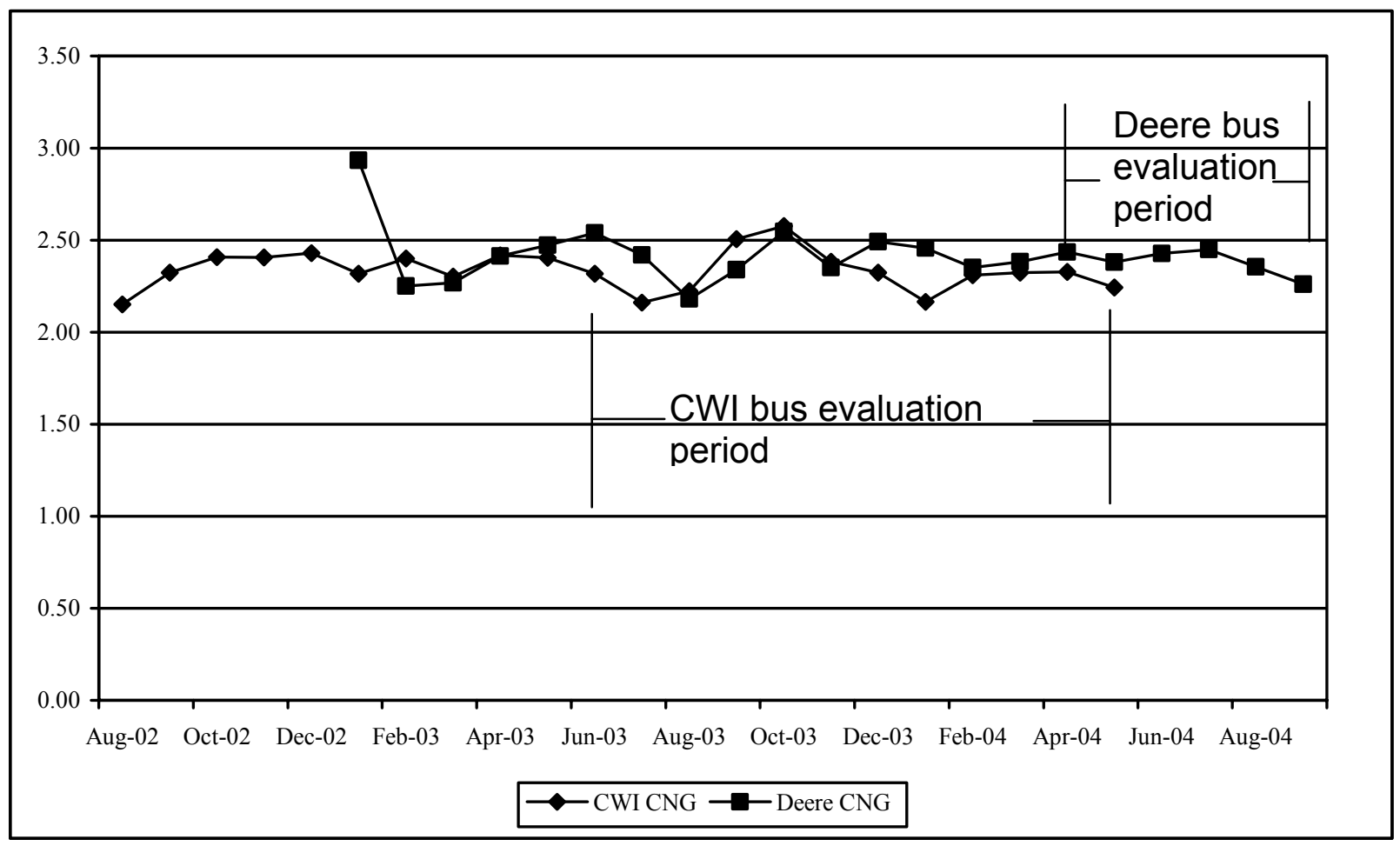

Figure 10. Monthly Fuel Economy (mpDGE) of CNG Buses at Bladensburg (All Data)

Since this evaluation, the WMATA diesel buses as a fleet have been modified to reduce emissions with DPFs, and some of the diesel buses have been repowered with newer EGRequipped engines. These modifications may have affected the fuel economy of the diesel buses.

The diesel fuel cost during the diesel bus evaluation period averaged $\$ 0.75$ per gallon. Diesel fuel cost during the CNG bus evaluation period averaged $\$ 1.33$ per gallon. CNG fuel costs during the CNG bus evaluation period averaged $\$ 1.19$ per DGE. These average costs were calculated based on monthly average costs and are shown in Appendix D.

Electricity required for operation of the fuel station added to the cost of the CNG fuel. WMATA estimated this cost to be approximately $\$ 300,000$ per year or $\$ 25,000$ per month. The approximate CNG use at this station has been 182,000 DGE per month. This translates into an increase of $\$ 0.14$ per DGE for electricity. Thus, the real cost of CNG averaged $\$ 1.33$ per DGE, the same as the recent average diesel fuel cost.

\section{Total Maintenance Costs}

Maintenance work orders for each bus in this study were collected as far back as they were available from WMATA. For the diesel buses, this included the last 10 months of operation at Bladensburg before the CNG buses started operation. Once the CNG buses started full operation at Bladensburg, the diesel buses were sent to another depot. For both sets of CNG buses, all of the maintenance work orders were collected back to start of operation for each vehicle. For the CWI CNG buses, the last 12 months of operation are the evaluation focus, and for the Deere CNG buses the last 6 months of operation are the evaluation focus. Appendix E provides detailed maintenance cost information by vehicle and study group. 
The evaluation periods were chosen to attempt to match the same operation and maintenance activities by only collecting data from the Bladensburg depot and using data from similar vehicle ages, based on hubodometer readings. However, there are slight differences. At the end of the evaluation period for the study group buses, the hubodometer readings were generally as follows: diesel buses, had accumulated 60,000-70,000 miles; CWI CNG buses, 50,000-60,000 miles; and Deere CNG buses, approximately 40,000 miles. There was one exception for the Deere buses: bus 2464 had approximately 20,000 miles at the end of the evaluation period. These relative ages are important because maintenance costs tend to go up slightly over time as buses age. Thus, the Deere buses should have measurably lower maintenance costs than the diesel buses. The CWI buses most likely do not have enough of an age difference to have measurably different maintenance costs compared with the diesel buses.

Warranty costs are generally not included in this analysis of maintenance costs. Warranty has been paid as a premium for the CNG buses in the purchase price and is not included in this operations analysis. Some parts were provided to WMATA at no cost, and some labor from CWI and Deere mechanics helped WMATA introduce the CNG buses and keep them operating. Any cost incurred by WMATA for the CNG buses that was not covered by warranty has been included in this analysis.

For DOE/NREL evaluations, accident repairs are typically removed because of their random nature, high cost, and potential to skew analysis results when they have no direct impact on the comparison being drawn in the evaluation. Accidents are only relevant if they indicate safety issues. Only one minor accident occurred during the WMATA study - to one of the diesel buses - and there were no costs reported associated with the repair. No significant safety issues were reported during the WMATA evaluation.

Tire costs at WMATA are part of a lease program and have not been included in this maintenance cost analysis. However, labor hours for tire work or parts associated with tire work have been included. Only costs for the tires themselves have not been included.

Labor costs for this evaluation have been kept constant at $\$ 50 /$ hour for all maintenance activities. Labor hours have been reported so this number can be adjusted to reflect another average mechanic rate as desired. Parts costs were taken from recent costs for those parts, and these costs were held constant for the evaluation.

Table 11 shows total maintenance costs for each study group for all data and for the evaluation periods. For the evaluation periods, the CWI CNG buses had total maintenance costs $12 \%$ lower than for the diesel buses, and the Deere CNG buses had total maintenance costs $2 \%$ lower than for the diesel buses. 
Table 11. Total Maintenance Costs

\begin{tabular}{|c|c|c|c|c|c|c|c|c|}
\hline \multirow[b]{2}{*}{ Vehicle } & \multicolumn{4}{|c|}{ All Data (10 Months) } & \multicolumn{4}{|c|}{ Evaluation Period (10 Months) } \\
\hline & Mileage & Parts (\$) & $\begin{array}{l}\text { Labor } \\
\text { Hours }\end{array}$ & $\begin{array}{l}\text { Cost (\$) } \\
\text { per Mile }\end{array}$ & Mileage & Parts (\$) & $\begin{array}{l}\text { Labor } \\
\text { Hours }\end{array}$ & $\begin{array}{l}\text { Cost (\$) } \\
\text { per Mile }\end{array}$ \\
\hline 2070 & 27,301 & $2,465.63$ & 315.6 & 0.668 & 27,301 & $2,465.63$ & 315.6 & 0.668 \\
\hline 2071 & 33,309 & $3,741.82$ & 297.2 & 0.558 & 33,309 & $3,741.82$ & 297.2 & 0.558 \\
\hline 2072 & 38,292 & $1,992.55$ & 262.8 & 0.395 & 38,292 & $1,992.55$ & 262.8 & 0.395 \\
\hline 2073 & 29,169 & $2,840.31$ & 342.9 & 0.685 & 29,169 & $2,840.31$ & 342.9 & 0.685 \\
\hline 2074 & 24,475 & $2,015.62$ & 321.5 & 0.739 & 24,475 & $2,015.62$ & 321.5 & 0.739 \\
\hline Total Diesel & 152,546 & $13,055.93$ & $1,540.0$ & & 152,546 & $13,055.93$ & $1,540.0$ & \\
\hline $\begin{array}{l}\text { Average per } \\
\text { Bus }\end{array}$ & 30,509 & $2,611.19$ & 308.0 & 0.590 & 30,509 & $2,611.19$ & 308.0 & 0.590 \\
\hline \multirow[b]{2}{*}{ Vehicle } & \multicolumn{4}{|c|}{ All Data } & \multicolumn{4}{|c|}{ Evaluation Period (12 Months) } \\
\hline & Mileage & Parts (\$) & $\begin{array}{l}\text { Labor } \\
\text { Hours }\end{array}$ & $\begin{array}{l}\text { Cost (\$) } \\
\text { per Mile }\end{array}$ & Mileage & Parts (\$) & $\begin{array}{l}\text { Labor } \\
\text { Hours }\end{array}$ & $\begin{array}{l}\text { Cost (\$) } \\
\text { per Mile }\end{array}$ \\
\hline 2302 & 44,531 & $4,428.23$ & 411.2 & 0.561 & 23,842 & $2,166.81$ & 234.5 & 0.583 \\
\hline 2303 & 58,147 & $2,922.35$ & 421.7 & 0.413 & 36,951 & $1,949.87$ & 261.2 & 0.406 \\
\hline 2304 & 52,180 & $3,089.44$ & 433.3 & 0.474 & 29,710 & $1,662.35$ & 237.2 & 0.455 \\
\hline 2307 & 49,367 & $3,967.37$ & 441.7 & 0.528 & 29,436 & $2,110.01$ & 235.2 & 0.471 \\
\hline 2309 & 45,516 & $3,254.37$ & 480.2 & 0.621 & 23,769 & $3,254.37$ & 310.7 & 0.790 \\
\hline $\begin{array}{l}\text { Total CWI } \\
\text { CNG }\end{array}$ & 249,741 & $18,678.74$ & $2,188.1$ & & 143,708 & $11,143.41$ & $1,278.8$ & \\
\hline $\begin{array}{l}\text { Average per } \\
\text { Bus }\end{array}$ & 49,948 & $3,735.75$ & 437.6 & 0.513 & 28,742 & $2,228.68$ & 255.8 & 0.522 \\
\hline \multirow[b]{2}{*}{ Vehicle } & \multicolumn{4}{|c|}{ All Data } & \multicolumn{4}{|c|}{ Evaluation Period (6 Months) } \\
\hline & Mileage & Parts (\$) & $\begin{array}{l}\text { Labor } \\
\text { Hours }\end{array}$ & $\begin{array}{l}\text { Cost (\$) } \\
\text { per Mile }\end{array}$ & Mileage & Parts (\$) & $\begin{array}{l}\text { Labor } \\
\text { Hours }\end{array}$ & $\begin{array}{l}\text { Cost (\$) } \\
\text { per Mile }\end{array}$ \\
\hline 2460 & 41,636 & $4,091.98$ & 503.4 & 0.703 & 14,773 & $1,902.11$ & 175.3 & 0.722 \\
\hline 2461 & 39,875 & $3,058.65$ & 503.6 & 0.708 & 16,162 & 598.32 & 106.5 & 0.366 \\
\hline 2462 & 42,490 & $3,471.63$ & 496.8 & 0.666 & 16,914 & 961.96 & 145.1 & 0.486 \\
\hline 2463 & 42,692 & $4,255.34$ & 541.9 & 0.734 & 16,619 & $1,410.27$ & 162.8 & 0.575 \\
\hline 2464 & 17,865 & $1,759.75$ & 428.4 & 1.297 & 9,053 & 568.83 & 147.7 & 0.880 \\
\hline $\begin{array}{l}\text { Total Deere } \\
\text { CNG }\end{array}$ & 184,558 & $16,637.35$ & $2,474.1$ & & 73,503 & $5,441.49$ & 737.4 & \\
\hline $\begin{array}{l}\text { Average per } \\
\text { Bus }\end{array}$ & 36,912 & $3,327.47$ & 494.8 & 0.760 & 14,701 & $1,088.30$ & 147.5 & 0.576 \\
\hline
\end{tabular}

"All Data" for the CWI CNG buses were generally from 8/02-5/04 and for the Deere CNG buses were generally from 2/03-9/04. The "Evaluation Period" was the final 12 months of data for the CWI CNG buses and the final 6 months for the Deere CNG buses. The longer "All Data" period is included to study how the maintenance costs have changed over a longer period.

One diesel bus had significantly lower maintenance costs than the other diesel buses. This was because of low frequency of unscheduled maintenance for this one bus. The other diesel buses had issues with brakes, hydraulics, air conditioning, transmission, and the engine. The CWI CNG buses had two high-cost buses — 2302 and 2309_caused by brake, transmission, engine, and cooling system repairs. The Deere CNG buses also had two high-cost buses: 2460 and 2464. For bus 2460, the cost was due to brake repairs and engine issues. Bus 2464 had significantly lower 
use owing to engine problems and damage to the destination sign and body of the bus that had to be repaired.

Figure 11, Figure 12, and Figure 13 show cumulative average maintenance cost for each of the study bus groups for the entire data collection. Diesel bus maintenance costs were generally above $\$ 0.500 /$ mile, with a slight increase at the end of the data period (Figure 11). CWI CNG bus maintenance costs averaged about $\$ 0.500 /$ mile for nearly the entire operating period (Figure 12). The Deere CNG buses had high maintenance costs at the beginning of operation, but these costs came down significantly as the buses started full operation around March-April 2004 (Figure 13). The early high maintenance costs for the Deere CNG buses were caused by work done to resolve issues of repowering these buses from the CWI engine to the Deere engine.

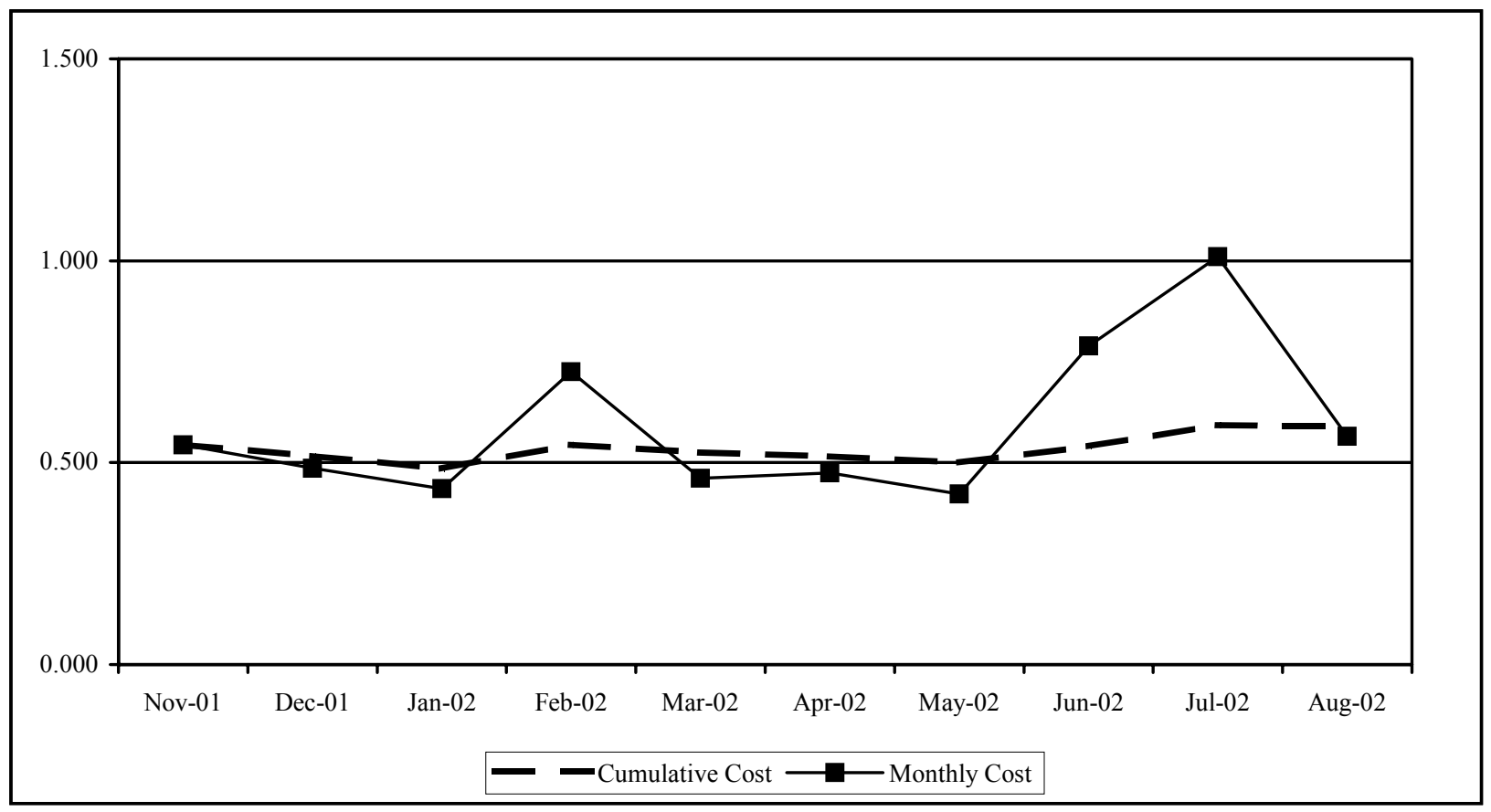

Figure 11. Monthly and Cumulative Maintenance Cost for Diesel Buses (\$/Mile, All Data) (for diesel buses, All Data $=$ Evaluation Period) 


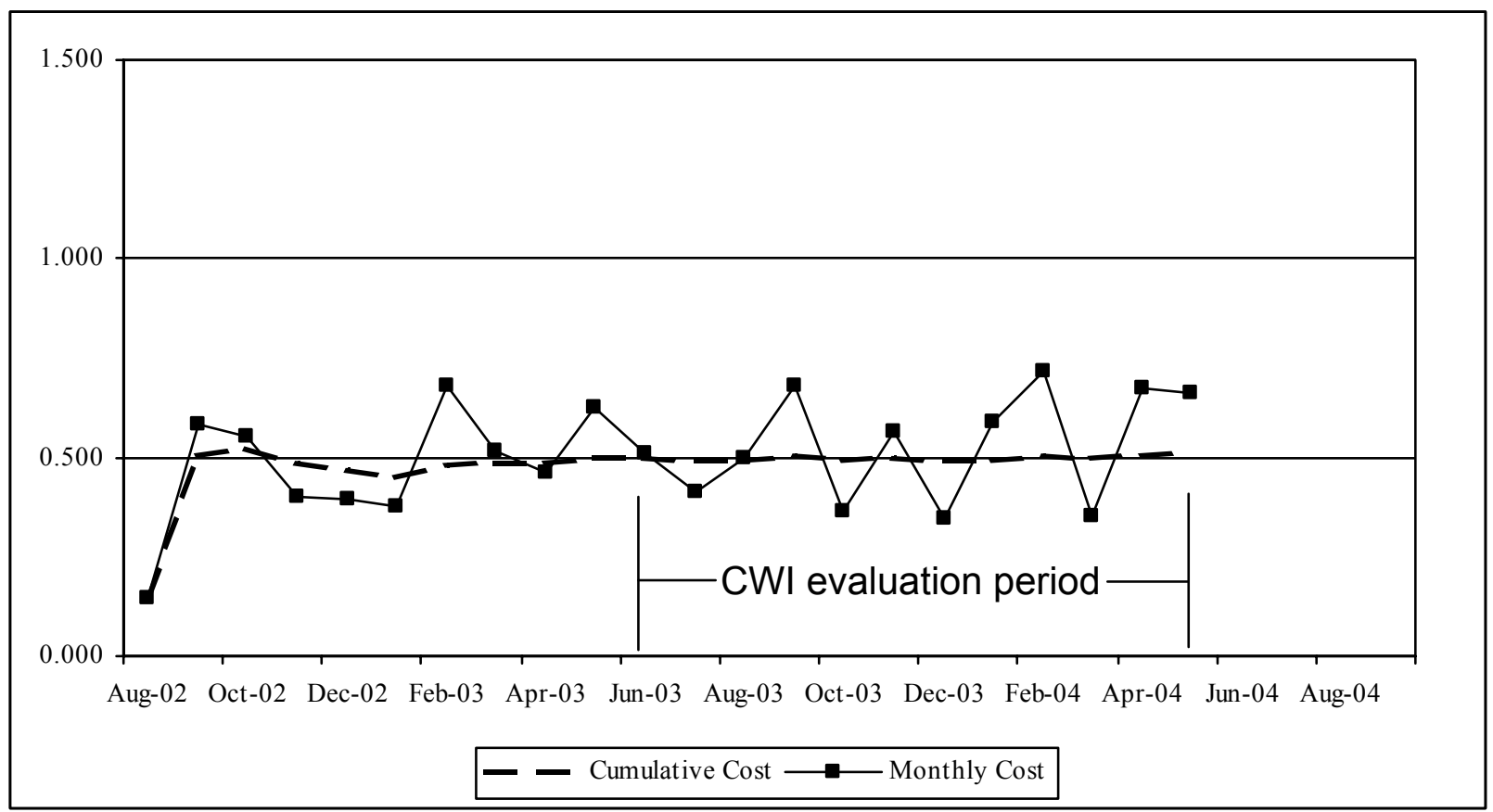

Figure 12. Monthly and Cumulative Maintenance Cost for CWI CNG Buses (\$/Mile, All Data)

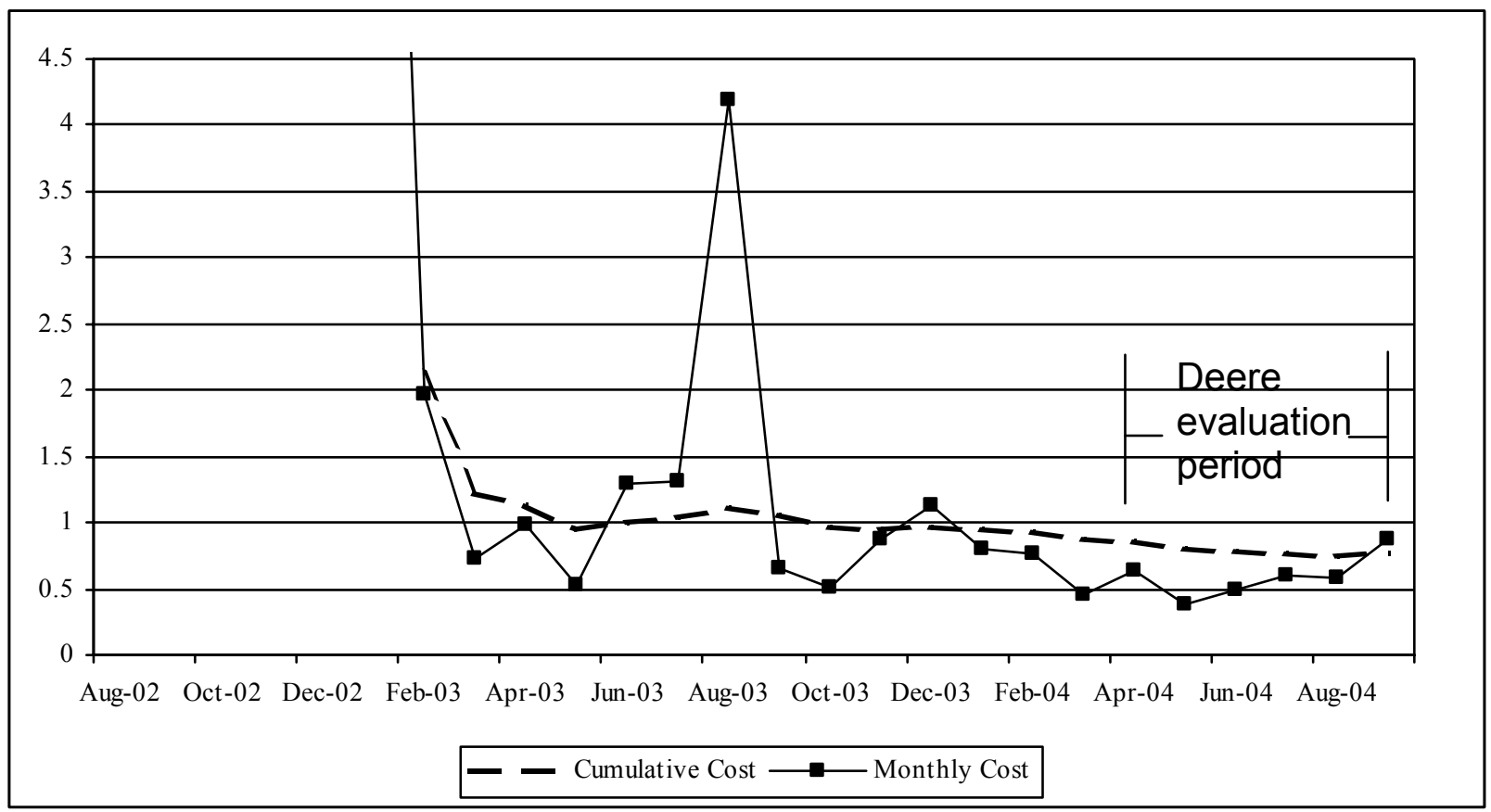

Figure 13. Monthly and Cumulative Maintenance Cost for Deere CNG Buses (\$/Mile, All Data) 


\section{Maintenance Costs by Vehicle System}

Table 12 shows maintenance costs by vehicle system and study group of buses. The vehicle system maintenance costs shown in the table include the following:

- Preventive maintenance inspections (PMI): only labor for inspections during preventive maintenance

- Engine- and fuel-related: exhaust, fuel, engine, non-lighting electrical, air intake, and cooling

- Cab, body, accessories, and hydraulics: includes body repairs, glass, and painting; cab and sheet metal repairs including seats and doors; accessory repairs such as radios and destination signs; and hydraulics for systems such as the wheelchair lift

- Brakes

- Heating, ventilation, and air conditioning (HVAC)

- Transmission

- Air, general: buses have significant need for compressed air to control brakes, throttle, door systems, and suspension; this category is for repairs of a general nature for the air system and not specifically associated with one of the systems listed in this category

- Tires: WMATA has a tire lease program, so only the mechanic time and parts other than the tires themselves are included in this category

- Lighting

- Frame, steering, and suspension

- Axles, wheels, and drive shaft.

Appendix $\mathrm{F}$ has detailed maintenance costs broken down by system for each study group. The top five vehicle systems based on maintenance costs are the same for each of the study groups for the evaluation period; however, the order is slightly different for each. Those five systems are PMI; engine/fuel-related; cab, body, accessories, and hydraulics; brakes; and HVAC. 
Table 12. Breakdown of Vehicle System Maintenance Costs (Evaluation Periods Only)

\begin{tabular}{|l|c|c|c|c|c|c|}
\hline \multicolumn{1}{|c|}{ System } & \multicolumn{2}{c|}{ Diesel } & \multicolumn{2}{c|}{ CWI CNG } & \multicolumn{2}{c|}{ Deere CNG } \\
\hline Cost/mi & $\begin{array}{c}\text { Percent } \\
\text { of Total } \\
(\%)\end{array}$ & $\begin{array}{c}\text { Cost/mi } \\
\mathbf{( \$ )}\end{array}$ & $\begin{array}{c}\text { Percent } \\
\text { of Total } \\
(\%)\end{array}$ & $\begin{array}{c}\text { Cost/mi } \\
\mathbf{( \$ )}\end{array}$ & $\begin{array}{c}\text { Percent } \\
\text { of Total } \\
\text { (\%) }\end{array}$ \\
\hline PMI & 0.170 & 29 & 0.121 & 23 & 0.139 & 24 \\
\hline Engine/Fuel-Related & 0.122 & 20 & 0.135 & 26 & 0.126 & 22 \\
\hline $\begin{array}{l}\text { Cab, Body, Accessories, } \\
\text { and Hydraulics }\end{array}$ & 0.104 & 17 & 0.109 & 21 & 0.170 & 29 \\
\hline Brakes & 0.067 & 11 & 0.034 & 6 & 0.066 & 11 \\
\hline HVAC & 0.039 & 7 & 0.034 & 6 & 0.030 & 5 \\
\hline Transmission & 0.035 & 6 & 0.030 & 6 & 0.005 & 1 \\
\hline Air, General & 0.016 & 3 & 0.003 & 1 & 0.003 & 1 \\
\hline $\begin{array}{l}\text { Frame, Steering, and } \\
\text { Suspension }\end{array}$ & 0.015 & 3 & 0.026 & 5 & 0.006 & 1 \\
\hline Tires & 0.013 & 2 & 0.010 & 2 & 0.010 & 2 \\
\hline Lighting & 0.006 & 1 & 0.017 & 3 & 0.006 & 1 \\
\hline $\begin{array}{l}\text { Axles, Wheels, and } \\
\text { Drive Shaft }\end{array}$ & 0.004 & 1 & 0.003 & 1 & 0.015 & 3 \\
\hline Total & $\mathbf{0 . 5 9 0}$ & $\mathbf{1 0 0}$ & $\mathbf{0 . 5 2 2}$ & $\mathbf{1 0 0}$ & $\mathbf{0 . 5 7 6}$ & $\mathbf{1 0 0}$ \\
\hline
\end{tabular}

The following discussion of maintenance costs by vehicle system focuses on the evaluation periods:

- Total engine/fuel-related-The CWI CNG buses had costs $11 \%$ higher, and the Deere CNG buses had costs 3\% higher than the diesel buses. These higher costs are expected for the CNG buses because of higher engine oil and fuel filter costs as well as costs for spark plugs, which are not required for the diesel buses. The following are descriptions of each of the system groups that constitute this category.

- Exhaust - The exhaust system maintenance was nearly the same for the CWI CNG and the diesel buses. The Deere CNG buses had 67\% higher maintenance costs than the diesel buses; the higher cost was due to repairs for the exhaust pipes and issues related to the turbocharger.

- Fuel-Both groups of CNG buses had higher fuel system maintenance costs (2.3 times higher for CWI CNG and 51\% higher for Deere CNG) than the diesel buses. This was due to more expensive fuel filters and troubleshooting. Some problems with the natural gas sensors were experienced.

- Engine - Engine maintenance was nearly the same for the CWI CNG (6\% higher) and diesel buses. The Deere CNG buses had 74\% higher maintenance costs compared with the diesel buses. The Deere CNG buses had troubleshooting costs and problems with the engine sensors such as the oxygen sensor.

- Non-lighting electrical-Both groups of CNG buses had higher maintenance costs for these systems (2.3 times higher for CWI CNG and 41\% higher for Deere CNG). 
High troubleshooting costs were attributed to this category related to spark plugs, batteries, and alternator repairs.

- Air intake - Both groups of CNG buses had higher maintenance costs for the airintake system (21 times higher for CWI CNG and 8.5 times higher for Deere CNG). This was due to the diesel buses having very low maintenance costs for air intake repairs and the $\mathrm{CNG}$ buses having their air filters replaced on a more regular basis. The diesel buses only had air-intake filter repairs with no troubleshooting labor reported.

- Cooling - Both groups of CNG buses had lower maintenance costs for the cooling system (64\% lower for CWI CNG and 69\% lower for Deere CNG). The diesel buses had problems with the radiator and main cooling fan. Significant labor was expended to troubleshoot and repair these problems, including several roadcalls.

- Cab, body, accessories, and hydraulics - The CWI CNG buses had 5\% higher maintenance costs for these systems than the diesel buses. The Deere CNG buses had $63 \%$ higher maintenance costs than the diesel buses. The Deere CNG buses had a few significant repairs for one of the rear doors and one of the destination signs.

- Frame, steering, and suspension-The CWI CNG buses had maintenance costs $73 \%$ higher than the diesel buses. Most of these repairs were for the suspension system, including shocks and leveling valves. There was one significant repair for the steering system. The Deere CNG buses had maintenance costs $60 \%$ lower than the diesel buses.

- Axles, wheels, and drive shaft - The CWI CNG buses had maintenance costs $25 \%$ lower than the diesel buses. The Deere CNG buses had maintenance costs 3.8 times higher than the diesel buses. The diesel bus maintenance costs for these systems were low, and the Deere $\mathrm{CNG}$ buses had a few significant repairs for the wheels and drive shaft.

- Brakes - The CWI CNG buses had brake maintenance costs $49 \%$ lower than the diesel buses. The Deere CNG buses had costs about the same as the diesel buses, which was not expected because the Deere CNG buses had lower mileage.

- Tires - Both groups of CNG buses had tire repair costs $23 \%$ lower than the diesel buses. Repair costs for tires were low for all three groups of buses.

- HVAC - Both groups of CNG buses had HVAC repair costs lower than the diesel buses (13\% lower for CWI CNG and 23\% lower for Deere CNG).

- $\quad$ PMI - Both groups of CNG buses had PMI costs lower than the diesel buses (29\% lower for CWI CNG and 18\% lower for Deere CNG). There was a difference in time for the evaluation period used for the diesel buses as compared to the CNG buses. There appears to have been a change in the standard number of hours of mechanic labor used for the inspection of buses between when the diesel bus evaluation period occurred and when the CNG bus evaluation period occurred. 
- Lighting-The CWI CNG buses had maintenance costs 2.8 times higher than the diesel buses. However, all three bus groups had low lighting costs. The CWI CNG buses had a few significant repairs, which required troubleshooting the wiring. The Deere CNG buses had essentially the same maintenance costs for lighting repairs as the diesel buses.

\section{Roadcalls}

A roadcall is defined in this report as an on-road failure of an in-service bus that required the bus be taken out of service or replaced on route. Roadcalls are a direct indicator of reliability for transit buses. Figure 14 and Figure 15 show miles between roadcalls (MBRC) for all roadcalls and for only engine- and fuel-related (exhaust, fuel, engine, non-lighting electrical, air intake, and cooling) roadcalls. A higher MBRC means higher reliability.

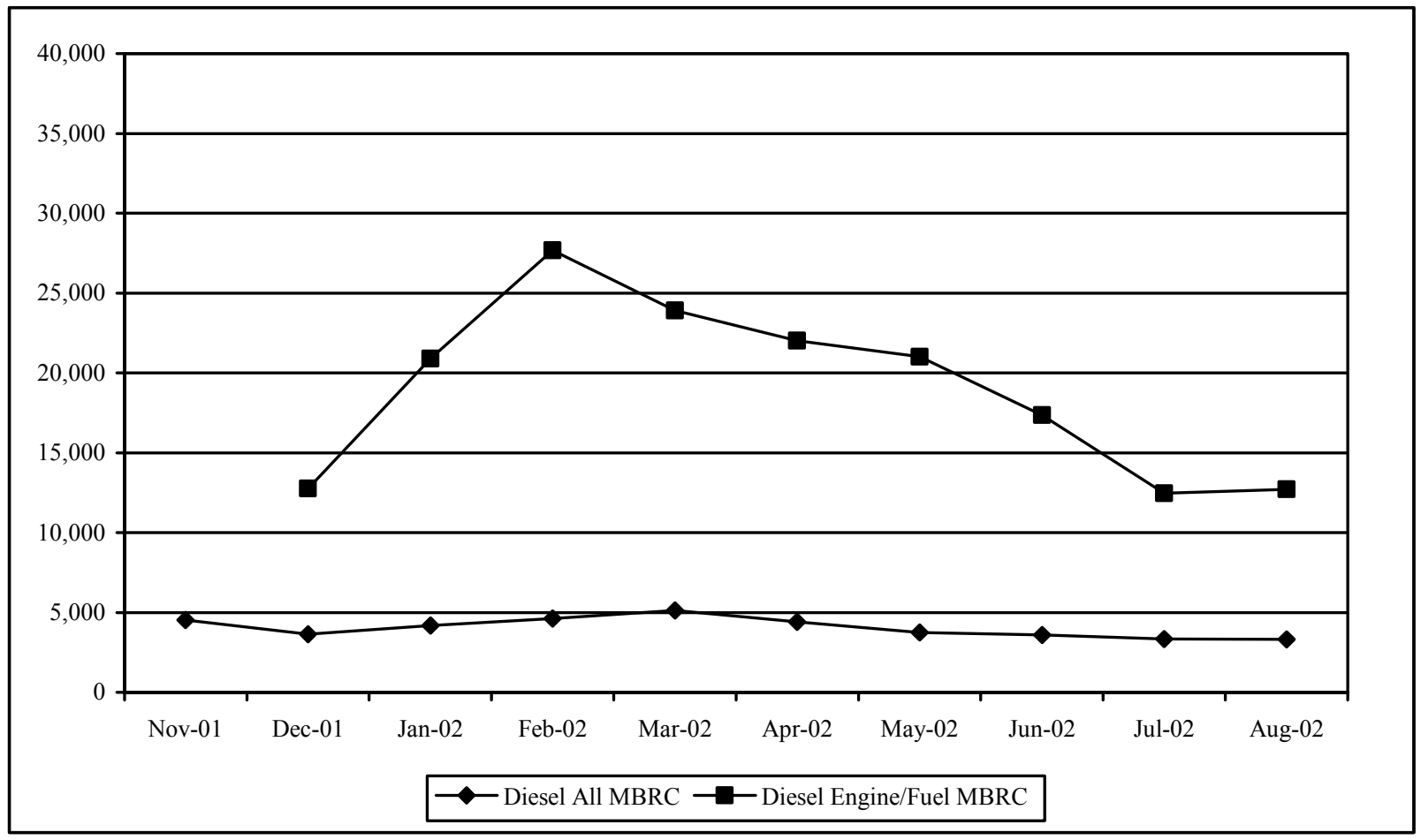

Figure 14. Cumulative MBRC for Diesel Buses (All Data) (for diesel buses, All Data $=$ Evaluation Period)

Figure 14 shows MBRC for the diesel buses. The MBRC for all roadcalls is below 5,000 miles for the entire data period shown. The MBRC for the engine- and fuel-related roadcalls was as high as about 27,000 miles and then dipped down below 15,000 miles. The lower MBRC for engine- and fuel-related roadcalls was due to engine and cooling system problems.

Figure 15 shows MBRC for both groups of CNG buses. The CWI CNG buses had MBRC for all roadcalls above 5,000 miles for all of the data collected. The MBRC for engine- and fuel-related roadcalls for CWI CNG buses was as high as 35,000 miles and ended around 23,000 miles. The drop from 35,000 miles during June-August 2003 was caused by five roadcalls: one for charging, one for exhaust, and three for the engine system. The CWI CNG buses had an MBRC for all roadcalls and for engine- and fuel-related roadcalls above the MBRC for the diesel buses. 


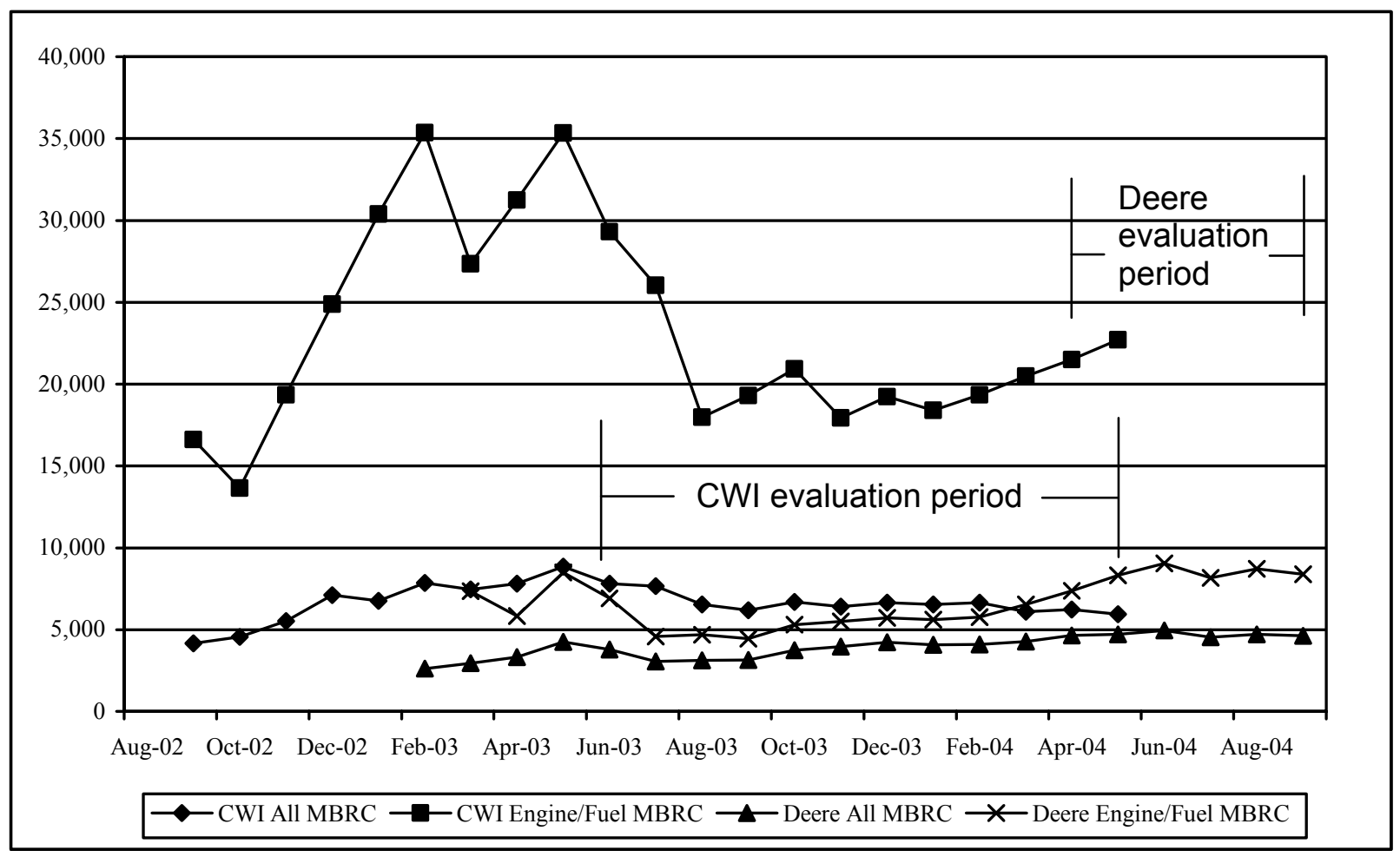

Figure 15. Cumulative MBRC for CNG Buses (All Data)

For the Deere CNG buses, the MBRC for all roadcalls ended at just under 5,000 miles. The MBRC for engine- and fuel-related roadcalls rose significantly during the last 6 months shown and ended at around 8,000 miles. Problems causing roadcalls for the engine- and fuel-related roadcalls included engine, exhaust, and cooling system issues. The last 6 months of operation showed the highest MBRC for both types of roadcalls for the Deere CNG buses.

Table 13 shows all roadcalls broken down by system for the evaluation period. For the diesel buses, the systems with the highest number of roadcalls were brakes, transmission, cooling, and farebox. For the CWI CNG buses, the systems with the highest number of roadcalls were farebox, doors and interlock, engine, and transmission. For the Deere CNG buses, the systems with the highest number of roadcalls were farebox, engine, and body exterior. 
Table 13. Summary of Roadcalls by System (Evaluation Periods)

\begin{tabular}{|l|c|c|c|c|c|c|}
\hline \multirow{2}{*}{ System } & \multicolumn{2}{c|}{ Diesel } & \multicolumn{2}{c|}{ CWI - CNG } & \multicolumn{2}{c|}{ Deere - CNG } \\
\cline { 2 - 7 } & Roadcalls & $\begin{array}{c}\text { Percent } \\
\text { (\%) }\end{array}$ & Roadcalls & $\begin{array}{c}\text { Percent } \\
(\%)\end{array}$ & Roadcalls & $\begin{array}{c}\text { Percent } \\
\text { (\%) }\end{array}$ \\
\hline HVAC & 2 & 4 & 0 & 0 & 0 & 0 \\
\hline Doors and Interlock & 2 & 4 & 4 & 14 & 0 & 0 \\
\hline Wipers and Washer & 0 & 0 & 0 & 0 & 1 & 7 \\
\hline Windows & 0 & 0 & 2 & 8 & 0 & 0 \\
\hline Body Exterior & 1 & 2 & 1 & 3 & 0 & 0 \\
\hline Body Interior & 1 & 2 & 1 & 3 & 2 & 14 \\
\hline Brakes & 8 & 18 & 1 & 3 & 0 & 0 \\
\hline Steering & 0 & 0 & 1 & 3 & 0 & 0 \\
\hline Suspension & 2 & 4 & 0 & 0 & 0 & 0 \\
\hline Tires & 1 & 2 & 0 & 0 & 0 & 0 \\
\hline Rear Axle & 0 & 0 & 0 & 0 & 1 & 7 \\
\hline Transmission & 7 & 15 & 3 & 10 & 0 & 0 \\
\hline Non-Lighting Electrical & 1 & 2 & 1 & 3 & 1 & 7 \\
\hline Lighting & 1 & 2 & 0 & 0 & 0 & 0 \\
\hline Cooling & 7 & 15 & 1 & 3 & 0 & 0 \\
\hline Exhaust & 0 & 0 & 1 & 3 & 0 & 0 \\
\hline Fuel & 2 & 4 & 1 & 3 & 0 & 0 \\
\hline Engine & 2 & 4 & 4 & 14 & 3 & 22 \\
\hline Wheelchair Lift/Ramp & 1 & 2 & 0 & 0 & 0 & 0 \\
\hline Farebox & 7 & 15 & 9 & 30 & 6 & 43 \\
\hline Horn & 1 & 2 & 0 & 0 & 0 & 0 \\
\hline Destination Sign & 1 & 2 & 0 & 0 & 0 & 0 \\
\hline Total & $\mathbf{4 7}$ & $\mathbf{1 0 0}$ & $\mathbf{3 0}$ & $\mathbf{1 0 0}$ & $\mathbf{1 4}$ & $\mathbf{1 0 0}$ \\
\hline
\end{tabular}

\section{Summary of Operating Costs}

Table 14 shows a summary of operating costs for the study groups, including fuel and total maintenance costs per mile. The diesel study group has two rows in the table: one with the diesel fuel cost average from the evaluation period and another calculated with an average diesel fuel cost from the same period as the CNG bus evaluation period. The average diesel cost per gallon was $\$ 0.75$ for the evaluation period and $\$ 1.33$ for the representative or recent evaluation period (the same period as the CWI CNG bus evaluation period). The CNG fuel costs were averaged over the evaluation period, and $\$ 0.14$ per gallon was added for electricity costs for operating the CNG compression and dispensing station (based on a $\$ 300,000$ per year cost for electricity). This CNG fuel cost does not include the operations and maintenance contract for the station (\$360,000 per year) because the diesel fuel station operation and maintenance costs were unknown for the evaluation periods.

The maintenance costs shown are for the evaluation period and include all maintenance actions. The total maintenance costs are similar for the three study groups, with the diesel group being slightly higher than the two CNG groups. For total operating costs, the representative diesel group was only $3 \%$ lower compared with the CWI CNG group and $7 \%$ lower compared with the 
Deere CNG group. The general conclusion is that the operating costs accounted for in this evaluation for the diesel and CNG buses are similar, and are most influenced by fuel cost and fuel economy.

Table 14. Total Operating Cost (\$/Mile, Evaluation Periods)

\begin{tabular}{|l|c|c|c|}
\hline \multicolumn{1}{|c|}{ Study Group } & Fuel Cost & Maintenance Cost & Total Cost \\
\hline Diesel (Evaluation Period) & 0.26 & 0.59 & $\mathbf{0 . 8 5}$ \\
\hline Diesel (Representative) & 0.47 & 0.59 & $\mathbf{1 . 0 6}$ \\
\hline CNG - CWI & 0.57 & 0.52 & $\mathbf{1 . 0 9}$ \\
\hline CNG - Deere & 0.56 & 0.58 & $\mathbf{1 . 1 4}$ \\
\hline
\end{tabular}

*The difference between diesel (evaluation period) and diesel (representative) is the fuel cost. Diesel (evaluation period) uses the actual diesel fuel cost during the evaluation period of the diesel buses, September 2001 to August 2002 (\$0.75/gal). Diesel (representative) uses the diesel fuel cost during the evaluation period of the CNG buses ( $\$ 1.33 / \mathrm{gal})$.

\section{Summary of Results}

The presented results focus on the evaluation period for each study group of buses: diesel buses, 12 months (9/2001-8/2002); CWI CNG buses, 12 months (6/2003-5/2004); Deere CNG buses, 6 months (4/2004-9/2004). The Deere CNG buses had a limited evaluation of 6 months because the implementation was a field test confirmation of the technology, which will be a full market introduction with the next Deere CNG bus order from WMATA. The CWI CNG bus propulsion technology was considered a fully implemented commercial product and had a full 12-month evaluation as did the CWI CNG technology. Diesel propulsion technology was used as the baseline for this evaluation.

Implementation Experience. WMATA was dedicated to a positive implementation of CNG buses and appeared to implement the CNG buses into its operation with ease. Work was done early to ensure the equipment (vehicles and facilities) was well matched to WMATA's operation. Management was reported to have been supportive while allowing depot staff to make their own implementation decisions. Because of all the work done before the buses and equipment were brought to the depot, the overall implementation experience was better than expected. WMATA also received good technical support from manufacturers and others.

Routes and Bus Use. The CNG and diesel buses at the Bladensburg depot were used randomly on 40-foot bus routes. The $\mathrm{CNG}$ buses did not have restrictions due to range or power. The diesel buses used in the evaluation operated from Bladensburg depot from 2001-2002 (before the use of the CNG buses). The CNG buses operated from Bladensburg depot starting in 2002.

Fuel Economy and Cost. The CNG buses had fuel economies $16 \%-18 \%$ lower than the diesel buses: 2.3-2.4 mpDGE for the CNG buses versus $2.8 \mathrm{mpg}$ for the diesel buses. This fuel economy difference is better than the $20 \%-25 \%$ fuel economy penalty for CNG shown in previous DOE/NREL transit bus studies and may be due to emission control hardware now required on diesel engines.

The CNG fuel cost averaged \$1.19/DGE during the evaluation period. Adding the electricity cost for the CNG compressor station (\$0.14/DGE), the total CNG fuel cost was \$1.33/DGE. The 
ULSD fuel cost during the evaluation period for the diesel bus operation at Bladensburg (2002) averaged $\$ 0.75 /$ gal. However, during the CNG bus evaluation period, the ULSD fuel cost averaged $\$ 1.33 / \mathrm{gal}$.

Total Maintenance Costs. For the evaluation periods, the CWI CNG buses had 12\% lower total maintenance costs than the diesel buses, and the Deere CNG buses had 2\% lower total maintenance costs than the diesel buses.

Engine- and Fuel-Related Maintenance Costs. The engine- and fuel-related systems are the air intake, cooling, exhaust, fuel, engine, and non-lighting electrical (cranking, charging, and ignition) systems. These vehicle systems are the most relevant when comparing the differences in diesel and CNG transit bus propulsion technologies. The CWI CNG buses had costs $11 \%$ higher than the diesel buses, and the Deere CNG buses had costs 3\% higher than the diesel buses. The higher maintenance cost for the CNG buses versus the diesel buses for these systems was expected because of higher-cost engine oil, fuel filters, and the addition of the spark plugs and ignition systems for the $\mathrm{CNG}$ buses.

Roadcalls. A roadcall is defined in this report as an on-road failure of an in-service bus requiring the bus to be taken out of service or replaced on route. Both CNG bus groups had better MBRC rates than the diesel buses. The CWI CNG buses had an all roadcall MBRC $44 \%$ higher and engine- and fuel-related roadcall MBRC $41 \%$ higher than the diesel buses. The Deere CNG buses had an all roadcall MBRC 58\% higher and engine- and fuel-related roadcall MBRC 16\% higher than the diesel buses.

Total Operating Costs. The total operating costs for the study buses were similar. The fuel costs for $\mathrm{CNG}$ and diesel during the CNG bus evaluation periods were the same at $\$ 1.33 / \mathrm{DGE}$. The total operating costs were as follows: diesel, $\$ 1.06 /$ mile; CWI CNG, $\$ 1.09 /$ mile; and Deere CNG, $\$ 1.14 /$ mile. The major contributing factors are the fuel costs and fuel economy. Significant changes in the fuel cost or fuel economy would change total operating costs significantly.

Future Bus Orders at WMATA. A subsequent CNG bus order consisted of $250 \mathrm{CNG}$ buses from Orion (model VII, low floor), which started delivery in 2005. Another CNG bus facility came online in 2005. After this CNG bus order, the next bus order is planned to be diesel and diesel hybrid buses. These diesel buses are required at WMATA to lower the average diesel bus age at the eight depots not currently operating CNG buses.

Status of the CNG Bus Propulsion Technologies. The CWI CNG bus propulsion technology appears from the evaluation to be a mature technology and is similar in operation and cost to the diesel bus technology. The Deere CNG bus propulsion technology was a field test confirmation during this project and only underwent a limited evaluation. However, by the end of the evaluation, the results indicated that this propulsion technology was maturing. WMATA and Deere have agreed to implement another 100 Deere CNG buses as part of WMATA's 250 CNG bus order, with delivery in 2005; this will be the first full market introduction of the Deere CNG bus propulsion technology. The order indicates WMATA's confidence in the Deere technology, even with higher engine maintenance costs. 


\section{References}

1. General Evaluation Plan: Fleet Test \& Evaluation Projects. NREL/BR-540-32392. Golden, CO: National Renewable Energy Laboratory, July 2002. Available in PDF at http://www.nrel.gov/docs/fy02osti/32392.pdf.

2. Evaluating the Emission Reduction Benefits of WMATA Natural Gas Buses. U.S. Department of Energy. NREL/FS-540-33280. Golden, CO: National Renewable Energy Laboratory, June 2003. Available in PDF at http://www.nrel.gov/vehiclesandfuels/ngvtf/pdfs/33280.pdf and http://www.nrel.gov/docs/fy03osti/33280.pdf.

3. Emission Testing of Washington Metropolitan Area Transit Authority (WMATA) Natural Gas and Diesel Transit Buses. NREL/TP-540-36355. Golden, CO: National Renewable Energy Laboratory, December 2005. Available in PDF at http://www.nrel.gov/vehiclesandfuels/ngvtf/pdfs/36355.pdf and http://www.nrel.gov/docs/fy06osti/36355.pdf.

4. "75 Largest Transit Agencies, Fiscal Year 2002 Ranked by Passenger Miles (Thousands).” American Public Transit Association Web Site, http://www.apta.com/research/stats/overview/75largest.cfm. Accessed on 4/10/06.

5. On-Road Development of the C-Gas Plus Engine in Heavy-Duty Vehicles. NREL/FS-54032871. U.S. Department of Energy. Golden, CO: National Renewable Energy Laboratory, June 2003. Available in PDF at http://www.nrel.gov/vehiclesandfuels/ngvtf/pdfs/32871.pdf and http://www.nrel.gov/docs/fy03osti/32871.pdf.

6. An Emission and Performance Comparison of the Natural Gas C-Gas Plus Engine in HeavyDuty Trucks. NREL/SR-540-32863. Golden, CO: National Renewable Energy Laboratory, April 2003. Available in PDF at http://www.nrel.gov/docs/fy03osti/32863.pdf.

7. On-Road Development of John Deere 6081 Natural Gas Engine. NREL/SR-540-30163. Golden, CO: National Renewable Energy Laboratory, September 2001. Available in PDF at http://www.nrel.gov/docs/fy01osti/30163.pdf.

8. Natural Gas Transit Users Group: Assisting Transit Agencies with Natural Gas Bus Technologies. U.S. Department of Energy. NREL/FS-540-37921 or DOE/GO-102005-2118. Golden, CO: National Renewable Energy Laboratory, April 2005. Available in PDF at http://www.nrel.gov/vehiclesandfuels/ngvtf/pdfs/037921ng bus.pdf and http://www.nrel.gov/docs/fy05osti/37921.pdf.

9. Alternative Fuel Transit Buses: Final Results from the National Renewable Energy Laboratory Vehicle Evaluation Program. NREL/TP-425-20513. Golden, CO: National Renewable Energy Laboratory, 1996.

10. Alternative Fuel Transit Buses-DART's LNG Bus Fleet: Final Results. U.S. Department of Energy. NREL/BR-540-28739. Golden, CO: National Renewable Energy Laboratory, October 2000. Available in PDF at http://www.nrel.gov/docs/fy01osti/28739.pdf. 


\section{Appendix A}

\section{Vehicle System Descriptions}




\begin{tabular}{|c|c|c|c|c|c|c|c|c|c|c|c|c|}
\hline Bus Company & \begin{tabular}{|c|} 
Vehicle \\
Number
\end{tabular} & Start Date & \begin{tabular}{|c|} 
Start \\
Odometer
\end{tabular} & \begin{tabular}{|l|} 
Test Fuel or \\
Technology
\end{tabular} & $\begin{array}{c}\text { Bus } \\
\text { Manufacturer }\end{array}$ & \begin{tabular}{c|} 
Bus \\
Model
\end{tabular} & 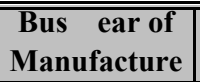 & $\begin{array}{c}\text { Vehicle Identification } \\
\text { Number (VIN) }\end{array}$ & $\begin{array}{c}\text { Engine } \\
\text { Manufacturer }\end{array}$ & $\begin{array}{l}\text { Engine ear of } \\
\text { Manufacture }\end{array}$ & $\begin{array}{l}\text { Engine } \\
\text { Model }\end{array}$ & $\begin{array}{l}\text { Engine Serial } \\
\text { Number (ESN) }\end{array}$ \\
\hline Washington & 2302 & $8 / 21 / 2002$ & "3,841 & $\overline{\mathrm{CNG}}$ & New Flyer & C40LF & 2001 & "5FYC2LP181U023236 & Cummins Westport & 2001 & C8.3G+ & $\overline{40164278}$ \\
\hline Metropolitan Area & 2303 & $8 / 14 / 2002$ & 3,734 & $\mathrm{CNG}$ & New Flyer & C40LF & 2001 & 5FYC2LP1X1U023237 & Cummins Westport & 2001 & C8.3G+ & 46149447 \\
\hline Transit Authority & 2304 & $8 / 27 / 2002$ & 3,966 & $\mathrm{CNG}$ & New Flyer & C40LF & 2001 & 5FYC2LP111U023238 & Cummins Westport & 2001 & C8.3G+ + & 46155233 \\
\hline \multirow[t]{12}{*}{ WMATA } & 2307 & $8 / 27 / 2002$ & 3,288 & $\mathrm{CNG}$ & New Flyer & C40LF & 2001 & 5FYC2LP111U023241 & Cummins Westport & 2001 & C8.3G+ + & 46154856 \\
\hline & 2309 & $8 / 20 / 2002$ & 3,876 & $\mathrm{CNG}$ & New Flyer & C40LF & 2001 & 5FYC2LP151U023243 & Cummins Westport & 2001 & $\mathrm{C} 8.3 \mathrm{G}^{+}$ & 46154843 \\
\hline & 2460 & $2 / 12 / 2003$ & 1,981 & $\mathrm{CNG}$ & New Flyer & C40LF & 2002 & 5FYC2LP172U023665 & John Deere & 2001 & $6081 \mathrm{H}$ & G6081H209814 \\
\hline & 2461 & $2 / 12 / 2003$ & 2,366 & $\mathrm{CNG}$ & New Flyer & C40LF & 2002 & 5FYC2LP192U023666 & John Deere & 2001 & $6081 \mathrm{H}$ & G6081H210481 \\
\hline & 2462 & $2 / 6 / 2003$ & 1,711 & $\mathrm{CNG}$ & New Flyer & C40LF & 2002 & 5FYC2LP102U023667 & John Deere & 2001 & $6081 \mathrm{H}$ & G6081H210480 \\
\hline & 2463 & $1 / 30 / 2003$ & 1,769 & $\mathrm{CNG}$ & New Flyer & C40LF & 2002 & 5FYC2LP122U023668 & John Deere & 2001 & $6081 \mathrm{H}$ & G6081H210482 \\
\hline & 2464 & $2 / 5 / 2003$ & 1,862 & $\mathrm{CNG}$ & New Flyer & C40LF & 2002 & 5FYC2LP142U023669 & John Deere & 2001 & $6081 \mathrm{H}$ & G6081H210479 \\
\hline & 2070 & $8 / 4 / 2000$ & 662 & Diesel & Orion Bus Ind. & 06.501 & 2000 & 1VH6H2A28Y6600308 & Detroit Diesel & 2000 & S50 & 04R0031725 \\
\hline & 2071 & $8 / 8 / 2000$ & 591 & Diesel & Orion Bus Ind. & 06.501 & 2000 & 1VH6H2A2XY6600309 & Detroit Diesel & 2000 & S50 & 04R0031729 \\
\hline & 2072 & $8 / 2 / 2000$ & 621 & Diesel & Orion Bus Ind. & 06.501 & 2000 & 1VH6H2A26Y6600310 & Detroit Diesel & 2000 & S50 & 04R0031766 \\
\hline & 2073 & $8 / 4 / 2000$ & 582 & Diesel & Orion Bus Ind. & 06.501 & 2000 & 1VH6H2A28Y6600311 & Detroit Diesel & 2000 & S50 & 04R0031730 \\
\hline & 2074 & $8 / 22 / 2000$ & 625 & Diesel & Orion Bus Ind. & 06.501 & 2000 & 1VH6H2A2XY6600312 & Detroit Diesel & 2000 & S50 & 04R0031798 \\
\hline
\end{tabular}




\section{Transit Agency: Washington Metropolitan Area Transit Authority (Washington, DC)}

\begin{tabular}{|c|c|c|c|}
\hline Vehicle System & Diesel & CNG (CWI) & CNG (Deere) \\
\hline \multicolumn{4}{|l|}{ General Bus Specifications } \\
\hline Bus Number & $2070-4$ & $2302-4,7,9$ & $2460-4$ \\
\hline Bus Manufacturer/Model & Orion/VI & New Flyer/C40LF & New Flyer/C40LF \\
\hline Bus Length, Ft. & 40 & 40 & 40 \\
\hline Bus Width \& Height, In. & 102,121 & 102,126 & 102,126 \\
\hline Wheel Base, In. & 278 & & \\
\hline Gross Vehicle Wt. Rating Total, lb. & 42,540 & 40,600 & 40,600 \\
\hline Curb Weight Total, lb. & 29,300 & 31,500 & 31,500 \\
\hline $\begin{array}{l}\text { Number of Passenger Seats with no } \\
\text { Wheelchairs on Board }\end{array}$ & 38 & 40 & 40 \\
\hline Number of Wheelchair Positions & 2 & 2 & 2 \\
\hline Maximum Number of Standees & 50 & 20 & 20 \\
\hline Air Conditioning? (Yes/No) & Yes & Yes & Yes \\
\hline Wheelchair Lift/Ramp? (Yes/No) & Yes & Yes & Yes \\
\hline \multicolumn{4}{|l|}{ Engine/Fuel System } \\
\hline Fuel Type(s)/Additives & ULSD/None & CNG/None & CNG/None \\
\hline Engine Manufacturer & Detroit Diesel Corp. & Cummins Westport & Deere Power Systems \\
\hline Engine Model Number & Series 50, DDEC IV & C Gas Plus & 6081HFN04 \\
\hline Year of Manufacture & 2000 & 2001 & 2001 \\
\hline EPA Engine Family Name & YDDXH08.5FJN & 2CEXH0505CBI & 2JDXH08.1001 \\
\hline Compression Ratio of engine & $15.0: 1$ & $10.1: 1$ & $11: 1$ \\
\hline Type of Ignition Aid used in engine & None & Spark Plugs & Spark Plugs \\
\hline EPA certified? (Yes/No) & Yes & Yes & Yes \\
\hline CARB Certified? (Yes/No) & Yes & Yes & Yes \\
\hline BHP Maximum and rpm & $275 \mathrm{bhp}$ at $2,100 \mathrm{rpm}$ & $280 \mathrm{bhp}$ at $2,400 \mathrm{rpm}$ & $280 \mathrm{bhp}$ at $2,200 \mathrm{rpm}$ \\
\hline Torque Maximum and rpm & $890 \mathrm{ft}-1 \mathrm{bs}$ at $1,200 \mathrm{rpm}$ & $850 \mathrm{ft}-1 \mathrm{bs}$ at $1,400 \mathrm{rpm}$ & $900 \mathrm{ft}-\mathrm{lbs}$ at $1,500 \mathrm{rpm}$ \\
\hline Displacement (L) & 8.5 & 8.3 & 8.1 \\
\hline Blower? (Yes/No) & No & No & $\mathrm{No}$ \\
\hline Turbocharger? (Yes/No) & Yes & Yes & Yes \\
\hline Mechanical or Electronic Fuel Inj.? & Electronic & $\mathrm{N} / \mathrm{A}$ & $\mathrm{N} / \mathrm{A}$ \\
\hline Direct Injection or Fumigation? & Injection & Fumigation & Fumigation \\
\hline Throttle for Intake Air? (Yes/No) & No & Yes & Yes \\
\hline Number of Fuel Storage Tanks & 1 & 7 & \\
\hline Total Useful Amount of Fuel Storage & $125 \mathrm{gal}$ & $21,161 \mathrm{scf}$ & $21,161 \mathrm{scf}$ \\
\hline \multicolumn{4}{|l|}{\begin{tabular}{||c|} 
Transmission \\
\end{tabular}} \\
\hline Manufacturer and Model Number & Allison/B400R & Allison/B400R & Allison/B400R \\
\hline \multicolumn{4}{|l|}{ Torque Conversion Ratio } \\
\hline Drive Axle Ratio & $5.24: 1$ & & \\
\hline Retarder? (Yes/No) & Yes & Yes & Yes \\
\hline \multicolumn{4}{|l|}{ Safety E uipment } \\
\hline Fire Detection (Yes/No) & Yes & Yes & Yes \\
\hline Fire Suppression (Yes/No) & Yes & Yes & Yes \\
\hline Vapor Detection (Yes/No) & No & Yes & Yes \\
\hline \multicolumn{4}{|l|}{ Emissions E uipment } \\
\hline Catalytic Converter (Yes/No) & $\mathrm{No}$ & Yes & Yes \\
\hline Diesel Particulate Trap (Yes/No) & No & No & $\mathrm{No}$ \\
\hline
\end{tabular}




\section{Appendix B}

Routes from Bladensburg 
Route Summary for Bladensburg

Effective Date 12/28/2003

\begin{tabular}{|c|c|c|c|c|c|c|c|c|c|c|c|c|c|c|c|c|}
\hline \multirow[b]{2}{*}{ LGRP } & \multirow[b]{2}{*}{ Route } & \multirow[b]{2}{*}{ Line Name } & \multirow[b]{2}{*}{ Day of Week } & \multicolumn{3}{|c|}{ No. of Buses } & \multicolumn{3}{|c|}{ Revenue } & \multicolumn{3}{|c|}{ Non-Revenue } & \multicolumn{3}{|c|}{ Total } & \multirow{2}{*}{$\begin{array}{c}\text { Vehicle } \\
\text { Type }\end{array}$} \\
\hline & & & & AM & PM & Base & Miles & Time & \begin{tabular}{|l|} 
Avg Speed \\
\end{tabular} & Miles & Time & \begin{tabular}{|l|} 
Avg Speed \\
\end{tabular} & Miles & Time & Avg Speed & \\
\hline \multirow[t]{4}{*}{14} & $\mathrm{X} 2$ & Benning Rd-H St & Weekday & 12 & 16 & 10 & 1403.03 & 149.05 & 9.41 & 209.79 & 15.63 & 13.42 & 1612.82 & 164.68 & 9.79 & \\
\hline & & & Saturday & 9 & 10 & & $\begin{array}{l}1097.56 \\
\end{array}$ & 105.73 & 10.38 & 119.78 & 8.33 & 14.37 & 1217.34 & 114.07 & 10.67 & \\
\hline & & & Sunday & 6 & 6 & & 847.55 & 75.53 & 11.22 & 62.58 & 4.33 & 14.44 & 910.13 & 79.87 & 11.40 & \\
\hline & & & Total & 75 & 96 & 50 & 8960.26 & 926.52 & 9.67 & 1231.31 & 90.83 & 13.56 & 10191.57 & 1017.35 & 10.02 & $\mathrm{~K} / \mathrm{A}$ \\
\hline \multirow[t]{4}{*}{18} & 96,97 & East Cap-Cardozo & Weekday & 6 & 3 & 0 & 208.85 & 20.77 & 10.06 & 80.79 & 4.53 & 17.82 & 289.64 & 25.30 & 11.45 & \\
\hline & & & Saturday & 0 & 0 & & 0.00 & 0.00 & & 0.00 & 0.00 & & 0.00 & 0.00 & & \\
\hline & & & Sunday & 0 & 0 & & 0.00 & 0.00 & & 0.00 & 0.00 & & 0.00 & 0.00 & & \\
\hline & & & Total & 30 & 15 & 0 & \begin{tabular}{|l|}
1044.25 \\
\end{tabular} & 103.83 & 10.06 & 403.95 & 22.67 & 17.82 & 1448.20 & 126.50 & 11.45 & NG \\
\hline \multirow[t]{4}{*}{25} & $\mathrm{X} 8$ & Maryland Avenue & Weekday & 2 & 2 & 1 & 162.00 & 19.12 & 8.47 & 13.62 & 0.90 & 15.13 & 175.62 & 20.02 & 8.77 & \\
\hline & & & Saturday & 1 & 1 & & \begin{tabular}{l|}
103.50 \\
\end{tabular} & 11.50 & 9.00 & 3.85 & 0.27 & 14.44 & 107.35 & 11.77 & 9.12 & \\
\hline & & & Sunday & 1 & 1 & & \begin{tabular}{l|l}
103.50 \\
\end{tabular} & 11.50 & 9.00 & 3.85 & 0.27 & 14.44 & 107.35 & 11.77 & 9.12 & \\
\hline & & & Total & 12 & 12 & 5 & \begin{tabular}{|l|l|}
1017.00 \\
\end{tabular} & 118.58 & 8.58 & 75.80 & 5.03 & 15.06 & 1092.80 & 123.62 & 8.84 & NG \\
\hline \multirow[t]{4}{*}{34} & H6 & Brookland-Ft Linc & Weekday & 4 & 5 & 3 & 698.21 & 50.22 & 13.90 & 59.92 & 4.17 & 14.38 & 758.13 & 54.38 & 13.94 & \\
\hline & & & Saturday & 2 & 2 & & 429.95 & 27.47 & 15.65 & 14.92 & 1.03 & 14.44 & 444.87 & 28.50 & \begin{tabular}{|c|}
15.61 \\
\end{tabular} & \\
\hline & & & Sunday & 1 & 1 & & 288.80 & 17.73 & 16.29 & 21.22 & 1.47 & 14.47 & 310.02 & 19.20 & 16.15 & \\
\hline & & & Total & 23 & 28 & 15 & 4209.80 & 296.28 & 14.21 & 335.74 & 23.33 & 14.39 & 4545.54 & 319.62 & 14.22 & $\mathrm{~S}$ \\
\hline \multirow[t]{4}{*}{35} & $\mathrm{H} 2,3,4$ & Crosstown & Weekday & 17 & 12 & 7 & 1278.04 & 123.92 & 10.31 & 207.49 & 13.88 & 14.95 & 1485.53 & 137.80 & 10.78 & \\
\hline & & & Saturday & 5 & 5 & & 869.30 & 74.58 & 11.66 & 47.90 & 3.33 & 14.37 & 917.20 & 77.92 & \begin{tabular}{c|c|}
11.77 \\
\end{tabular} & \\
\hline & & & Sunday & 5 & 5 & & 651.40 & 52.68 & 12.36 & 95.80 & 6.67 & 14.37 & 747.20 & 59.35 & 12.59 & \\
\hline & & & Total & 95 & 70 & 35 & 7910.90 & 746.85 & 10.59 & 1181.15 & 79.42 & 14.87 & 9092.05 & 826.27 & \begin{tabular}{c|c|}
11.00 \\
\end{tabular} & $\mathrm{NG}$ \\
\hline \multirow[t]{4}{*}{37} & $\bar{D} 5$ & Mac Blvd-Geotown & Weekday & 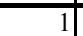 & 1 & 0 & 40.80 & 3.33 & 12.24 & 37.87 & 2.18 & 17.35 & 78.67 & 5.52 & 14.26 & \\
\hline & & & Saturday & 0 & 0 & & 0.00 & 0.00 & & 0.00 & 0.00 & & 0.00 & 0.00 & & \\
\hline & & & Sunday & 0 & 0 & & 0.00 & 0.00 & & 0.00 & 0.00 & & 0.00 & 0.00 & & \\
\hline & & & Total & 5 & 5 & 0 & 204.00 & 16.67 & 12.24 & 189.35 & 10.92 & 17.35 & 393.35 & 27.58 & 14.26 & NG \\
\hline \multirow[t]{4}{*}{44} & U8 & Cap Hts-Benn Hts & Weekday & 7 & 7 & 4 & 912.84 & 80.30 & 11.37 & 99.50 & 6.30 & 15.79 & 1012.34 & 86.60 & 11.69 & \\
\hline & & & Saturday & 2 & $3 \mid$ & & 600.60 & 47.30 & 12.70 & 46.31 & 2.93 & 15.79 & 646.91 & 50.23 & 12.88 & \\
\hline & & & Sunday & 2 & 2 & & 423.29 & 30.77 & 13.76 & 42.07 & 2.53 & 16.61 & 465.36 & 33.30 & 13.97 & \\
\hline & & & Total & 39 & 40 & 20 & 5588.09 & 479.57 & 11.65 & 585.88 & 36.97 & 15.85 & 6173.97 & 516.53 & 11.95 & $\mathrm{NG}$ \\
\hline \multirow[t]{4}{*}{45} & $\bar{D} 8$ & Hospital Center & Weekday & 7 & 11 & 5 & 946.16 & 94.45 & 10.02 & 112.22 & 7.32 & 15.34 & 1058.38 & 101.77 & 10.40 & \\
\hline & & & Saturday & 5 & 6 & & 712.40 & 64.05 & 11.12 & 93.85 & 5.92 & 15.86 & 806.25 & 69.97 & 11.52 & \\
\hline & & & Sunday & 3 & $3 \mid$ & & 417.64 & 36.27 & 11.52 & 33.99 & 2.13 & 15.93 & 451.63 & 38.40 & 11.76 & \\
\hline & & & Total & 43 & 64 & 25 & 5860.84 & 572.57 & 10.24 & 688.94 & 44.63 & 15.44 & 6549.78 & 617.20 & 10.61 & $\mathrm{M}$ \\
\hline \multirow[t]{4}{*}{49} & $\mathrm{~B} 8,9$ & Ft Lincoln Shuttle & Weekday & 4 & 3 & 1 & 217.25 & 18.70 & 11.62 & 14.57 & 1.23 & 11.81 & 231.82 & 19.93 & 11.63 & \\
\hline & & & Saturday & 0 & 0 & & 0.00 & 0.00 & & 0.00 & 0.00 & & 0.00 & 0.00 & & \\
\hline & & & Sunday & 0 & 0 & & 0.00 & 0.00 & & 0.00 & 0.00 & & 0.00 & 0.00 & & \\
\hline & & & Total & 20 & 15 & 5 & 1086.25 & 93.50 & 11.62 & 72.85 & 6.17 & \begin{tabular}{l|l|}
11.81 \\
\end{tabular} & 1159.10 & 99.67 & 11.63 & $\mathrm{~S}$ \\
\hline \multirow[t]{4}{*}{55} & $\mathrm{D} 1,3,6$ & Sibley-Stad Arm & Weekday & 22 & 11 & 8 & 1552.54 & 156.57 & 9.92 & 281.08 & 19.52 & 14.40 & 1833.62 & 176.08 & 10.41 & \\
\hline & & & Saturday & 5 & 5 & & 937.26 & 77.30 & 12.12 & 77.57 & 5.50 & 14.10 & 1014.83 & 82.80 & 12.26 & \\
\hline & & & Sunday & 5 & 5 & & \begin{tabular}{l|l|}
691.13 \\
\end{tabular} & 55.05 & 12.55 & 139.72 & 10.48 & 13.33 & 830.85 & 65.53 & 12.68 & \\
\hline & & & Total & 120 & 65 & 40 & 9391.09 & 915.18 & 10.26 & 1622.69 & 113.57 & 14.29 & 11013.78 & 1028.75 & 10.71 & $\mathrm{NG}$ \\
\hline
\end{tabular}




\begin{tabular}{|c|c|c|c|c|c|c|c|c|c|c|c|c|c|c|c|c|}
\hline \multirow[b]{2}{*}{ LGRP } & \multirow[b]{2}{*}{ Route } & \multirow[b]{2}{*}{ Line Name } & \multirow[b]{2}{*}{ Day of Week } & \multicolumn{3}{|c|}{ No. of Buses } & \multicolumn{3}{|c|}{ Revenue } & \multicolumn{3}{|c|}{ Non-Revenue } & \multicolumn{3}{|c|}{ Total } & \multirow{2}{*}{$\begin{array}{c}\text { Vehicle } \\
\text { Type }\end{array}$} \\
\hline & & & & $\mathbf{A M}$ & PM & Base & Miles & Time & \begin{tabular}{|l|} 
Avg Speed \\
\end{tabular} & Miles & Time & \begin{tabular}{|l|} 
Avg Speed \\
\end{tabular} & Miles & Time & Avg Speed & \\
\hline \multirow[t]{4}{*}{56} & D4 & Ivy City-Un Stat & Weekday & 3 & 3 & 2 & 423.80 & 39.82 & 10.64 & 14.44 & 0.95 & 15.20 & 438.24 & \begin{tabular}{|l|}
40.77 \\
\end{tabular} & 10.75 & \\
\hline & & & Saturday & 2 & 2 & & 326.75 & 29.90 & 10.93 & 24.64 & 2.17 & 11.37 & 351.39 & 32.07 & 10.96 & \\
\hline & & & Sunday & 2 & $2 \mid$ & & 219.98 & 18.30 & 12.02 & 44.98 & 2.98 & 15.08 & 264.96 & 21.28 & 12.45 & \\
\hline & & & Total & 19 & 19 & 10 & 2665.73 & 247.28 & 10.78 & 141.82 & 9.90 & 14.33 & 2807.55 & 257.18 & 10.92 & $\mathrm{~S}$ \\
\hline \multirow[t]{4}{*}{57} & V5 & Fx Vill-Lenf Plaz & Weekday & 3 & 0 & 0 & 28.20 & 2.13 & 13.22 & 23.25 & 1.62 & 14.38 & 51.45 & 3.75 & 13.72 & \\
\hline & & & Saturday & 0 & 0 & & 0.00 & 0.00 & & 0.00 & 0.00 & & 0.00 & 0.00 & & \\
\hline & & & Sunday & 0 & 0 & & 0.00 & 0.00 & & 0.00 & 0.00 & & 0.00 & 0.00 & & \\
\hline & & & Total & 15 & 0 & 0 & 141.00 & 10.67 & 13.22 & 116.25 & 8.08 & 14.38 & 257.25 & 18.75 & 13.72 & $\mathrm{NG}$ \\
\hline \multirow[t]{4}{*}{62} & H1 & Brookland-Pot Pk & Weekday & 4 & 4 & 0 & 89.19 & 10.92 & 8.17 & 92.14 & 6.55 & 14.07 & 181.33 & 17.47 & 10.38 & \\
\hline & & & Saturday & 0 & 0 & & 0.00 & 0.00 & & 0.00 & 0.00 & & 0.00 & 0.00 & & \\
\hline & & & Sunday & 0 & 0 & & 0.00 & 0.00 & & 0.00 & 0.00 & & 0.00 & 0.00 & & \\
\hline & & & Total & 20 & 20 & 0 & 445.95 & 54.58 & 8.17 & 460.70 & 32.75 & 14.07 & 906.65 & 87.33 & 10.38 & $\mathrm{NG}$ \\
\hline \multirow[t]{4}{*}{74} & $81,82,83,86$ & Maryland & Weekday & 12 & 13 & 7 & 1816.49 & 131.00 & 13.87 & 321.65 & 12.30 & 26.15 & 2138.14 & 143.30 & 14.92 & \\
\hline & & & Saturday & 6 & 6 & & 788.78 & 52.98 & 14.89 & $\begin{array}{ll}147.09 \\
\end{array}$ & 6.43 & 22.86 & 935.87 & 59.42 & 15.75 & \\
\hline & & & Sunday & 6 & 6 & & 653.73 & 42.15 & 15.51 & 141.45 & 5.77 & 24.53 & 795.18 & 47.92 & 16.60 & \\
\hline & & & Total & 72 & 77 & 35 & 10524.96 & 750.13 & 14.03 & 1896.79 & 73.70 & 25.74 & 12421.75 & 823.83 & 15.08 & $\mathrm{NG}$ \\
\hline \multirow[t]{4}{*}{78} & $\overline{\mathrm{U} 4}$ & Sher Rd-Riv Terr & Weekday & 3 & \begin{tabular}{c|}
3 \\
\end{tabular} & 1 & 367.10 & 28.37 & 12.94 & 68.40 & 5.00 & 13.68 & 435.50 & 33.37 & 13.05 & \\
\hline & & & Saturday & 1 & 1 & & 196.00 & 15.03 & 13.04 & 34.20 & 2.33 & 14.66 & 230.20 & \begin{tabular}{ll|}
17.37 \\
\end{tabular} & 13.26 & \\
\hline & & & Sunday & 1 & 1 & & 190.40 & 14.17 & 13.44 & 41.04 & 2.80 & 14.66 & 231.44 & \begin{tabular}{c|c|}
16.97 \\
\end{tabular} & 13.64 & \\
\hline & & & Total & 17 & 17 & 5 & 2221.90 & 171.03 & 12.99 & 417.24 & 30.13 & 13.85 & 2639.14 & 201.17 & 13.12 & $\mathrm{~S}$ \\
\hline \multirow[t]{4}{*}{81} & 42 & Mount Pleasant & Weekday & 1 & 4 & 0 & 96.89 & 15.37 & 6.31 & 92.33 & 6.82 & 13.54 & 189.22 & 22.18 & 8.53 & \\
\hline & & & Saturday & 0 & 0 & & 0.00 & 0.00 & & 0.00 & 0.00 & & 0.00 & 0.00 & & \\
\hline & & & Sunday & 0 & 0 & & 0.00 & 0.00 & & 0.00 & 0.00 & & 0.00 & 0.00 & & \\
\hline & & & Total & 5 & 20 & 0 & 484.45 & \begin{tabular}{ll|}
76.83 \\
\end{tabular} & 6.31 & 461.65 & 34.08 & 13.54 & 946.10 & 110.92 & 8.53 & $\mathrm{NG}$ \\
\hline \multirow[t]{4}{*}{86} & 80 & North Capitol St & Weekday & 13 & 14 & 10 & 1333.17 & 160.03 & 8.33 & 158.65 & 10.30 & 15.40 & 1491.82 & 170.33 & 8.76 & \\
\hline & & & Saturday & 5 & 5 | & & 834.15 & 86.88 & 9.60 & 79.17 & 5.07 & 15.63 & 913.32 & 91.95 & \begin{tabular}{c|c|}
9.93 \\
\end{tabular} & \\
\hline & & & Sunday & 4 & 5 & & 640.07 & 61.42 & 10.42 & 65.81 & 4.30 & 15.30 & 705.88 & 65.72 & 10.74 & \\
\hline & & & Total & 74 & 80 & 50 & 8140.07 & 948.47 & 8.58 & 938.23 & 60.87 & 15.41 & 9078.30 & 1009.33 & 8.99 & $\mathrm{NG}$ \\
\hline \multirow[t]{4}{*}{93} & $30,32,34,35,36$ & Pennsylvania Ave & Weekday & 13 & 5 & 0 & 331.75 & 37.63 & 8.82 & 251.43 & 15.90 & 15.81 & 583.18 & 53.53 & 10.89 & \\
\hline & & & Saturday & 0 & 0 & & 0.00 & 0.00 & & 0.00 & 0.00 & & 0.00 & 0.00 & & \\
\hline & & & Sunday & 0 & 0 & & 0.00 & 0.00 & & 0.00 & 0.00 & & 0.00 & 0.00 & & \\
\hline & & & Total & 65 & 25 & 0 & 1658.75 & 188.17 & 8.82 & 1257.15 & 79.50 & 15.81 & 2915.90 & 267.67 & 10.89 & $\mathrm{NG}$ \\
\hline \multirow[t]{4}{*}{95} & $\mathrm{~W} 4$ & Deanwood-Alab Ave & Weekday & 0 & 2 & 0 & 79.25 & 6.78 & 11.68 & 31.40 & 1.43 & 21.91 & 110.65 & 8.22 & 13.47 & \\
\hline & & & Saturday & 0 & 0 & & 0.00 & 0.00 & & 0.00 & 0.00 & & 0.00 & 0.00 & & \\
\hline & & & Sunday & 0 & 0 & & 0.00 & 0.00 & & 0.00 & 0.00 & & 0.00 & 0.00 & & \\
\hline & & & Total & 0 & 10 & 0 & 396.25 & 33.92 & 11.68 & 157.00 & 7.17 & 21.91 & 553.25 & 41.08 & \begin{tabular}{l|l|}
13.47 \\
\end{tabular} & $\mathrm{NG}$ \\
\hline 101 & G8 & Rhode Island Ave & Weekday & 11 & 10 & 4 & 929.36 & 94.37 & 9.85 & 134.04 & 9.55 & 14.04 & 1063.40 & 103.92 & 10.23 & \\
\hline & & & Saturday & 3 & 3 & & 617.09 & 50.52 & 12.22 & 39.37 & 2.73 & 14.40 & 656.46 & 53.25 & 12.33 & \\
\hline & & & Sunday & 3 & $4 \mid$ & & 505.58 & 38.85 & 13.01 & 26.30 & 1.83 & 14.35 & 531.88 & 40.68 & 13.07 & \\
\hline & & & Total & 61 & 57 & 20 & 5769.47 & 561.20 & 10.28 & $\begin{array}{l}735.87 \\
\end{array}$ & 52.32 & 14.07 & 6505.34 & 613.52 & 10.60 & $\mathrm{NG}$ \\
\hline 134 & $\mathrm{U} 2$ & Minn Ave-Anac & Weekday & 3 & 3 & 2 & 272.70 & 32.33 & 8.43 & 82.69 & 5.75 & 14.38 & 355.39 & 38.08 & 9.33 & \\
\hline & & & Saturday & 0 & 0 & & 0.00 & 0.00 & & 0.00 & 0.00 & & 0.00 & 0.00 & & \\
\hline & & & Sunday & 0 & 0 & & 0.00 & 0.00 & & 0.00 & 0.00 & & 0.00 & 0.00 & & \\
\hline & & & Total & 15 & 15 & 10 & 1363.50 & 161.67 & 8.43 & 413.45 & 28.75 & 14.38 & 1776.95 & 190.42 & 9.33 & $\mathrm{NG}$ \\
\hline
\end{tabular}




\begin{tabular}{|c|c|c|c|c|c|c|c|c|c|c|c|c|c|c|c|c|}
\hline \multirow[b]{2}{*}{ LGRP } & \multirow[b]{2}{*}{ Route } & \multirow[b]{2}{*}{ Line Name } & \multirow[b]{2}{*}{ Day of Week } & \multicolumn{3}{|c|}{ No. of Buses } & \multicolumn{3}{|c|}{ Revenue } & \multicolumn{3}{|c|}{ Non-Revenue } & \multicolumn{3}{|c|}{ Total } & \multirow{2}{*}{$\begin{array}{c}\text { Vehicle } \\
\text { Type }\end{array}$} \\
\hline & & & & $\mathbf{A M}$ & PM & Base & Miles & Time & \begin{tabular}{|l|} 
Avg Speed \\
\end{tabular} & Miles & Time & Avg Speed & Miles & Time & Avg Speed & \\
\hline \multirow[t]{4}{*}{135} & U5,6 & Mayfair-Mars Hgts & Weekday & 4 & 5 & 3 & 685.02 & 66.22 & 10.35 & 95.67 & 6.80 & 14.07 & 780.69 & 73.02 & 10.69 & \\
\hline & & & \begin{tabular}{|l|} 
Saturday \\
\end{tabular} & 3 & 3 & & 576.33 & 49.27 & 11.70 & 43.48 & 2.80 & 15.53 & 619.81 & \begin{tabular}{|c|}
52.07 \\
\end{tabular} & 11.90 & \\
\hline & & & Sunday & 2 & 2 & & 379.00 & 32.57 & 11.64 & 28.58 & 1.87 & 15.31 & 407.58 & 34.43 & 11.84 & \\
\hline & & & Total & 25 & 30 & 15 & 4380.43 & 412.92 & 10.61 & 550.41 & 38.67 & 14.23 & 4930.84 & 451.58 & 10.92 & $\mathrm{NG}$ \\
\hline \multirow[t]{4}{*}{150} & $\overline{\mathrm{B} 2}$ & Blad Rd-Anacostia & Weekday & 15 & 14 & 7 & 1634.17 & 147.08 & 11.11 & 137.26 & 9.72 & 14.13 & 1771.43 & 156.80 & \begin{tabular}{l|l}
11.30 \\
\end{tabular} & \\
\hline & & & Saturday & 5 & 6 & & 1060.91 & 79.92 & 13.28 & 30.45 & 2.23 & 13.63 & 1091.36 & 82.15 & 13.28 & \\
\hline & & & Sunday & 4 & 5 & & 863.24 & 60.58 & 14.25 & 19.72 & 1.43 & 13.76 & 882.96 & 62.02 & \begin{tabular}{l|l|}
14.24 \\
\end{tabular} & \\
\hline & & & Total & 84 & 81 & 35 & 10095.00 & 875.92 & 11.53 & 736.47 & 52.25 & 14.10 & \begin{tabular}{|l|}
10831.47 \\
\end{tabular} & 928.17 & \begin{tabular}{|c|}
11.67 \\
\end{tabular} & NG \\
\hline \multirow[t]{4}{*}{151} & $\mathrm{X} 1,3$ & Benning Road & Weekday & 10 & 7 & 0 & 191.87 & 20.20 & 9.50 & 213.95 & 13.95 & 15.34 & 405.82 & 34.15 & 11.88 & \\
\hline & & & \begin{tabular}{|l|} 
Saturday \\
\end{tabular} & 0 & 0 & & 0.00 & 0.00 & & 0.00 & 0.00 & & 0.00 & 0.00 & & \\
\hline & & & Sunday & 0 & 0 & & 0.00 & 0.00 & & 0.00 & 0.00 & & 0.00 & 0.00 & & \\
\hline & & & Total & 50 & 35 & 0 & 959.35 & 101.00 & 9.50 & 1069.75 & 69.75 & 15.34 & 2029.10 & 170.75 & 11.88 & NG \\
\hline \multirow[t]{4}{*}{514} & B99 & Bus Operator Shuttle & Weekday & 1 & 1 & 1 & 134.40 & 14.40 & 9.33 & 0.28 & 0.07 & 4.20 & 134.68 & 14.47 & 9.31 & \\
\hline & & & Saturday & 1 & 1 & & 109.20 & 11.70 & 9.33 & 0.28 & 0.07 & 4.20 & 109.48 & 11.77 & \begin{tabular}{l|l|l}
9.30 \\
\end{tabular} & \\
\hline & & & Sunday & 1 & 1 & & 109.20 & 11.70 & 9.33 & 0.28 & 0.07 & 4.20 & 109.48 & 11.77 & 9.30 & \\
\hline & & & Total & 7 & 7 & 5 & 890.40 & 95.40 & 9.33 & 1.96 & 0.47 & 4.20 & 892.36 & 295.87 & 9.31 & $\mathrm{M}$ \\
\hline \multirow[t]{4}{*}{544} & $\begin{array}{l}\mathrm{P} 1,2,6 \\
\end{array}$ & Anac-Eckington & Weekday & 1 & 3 & 0 & 106.30 & 11.40 & 9.32 & 43.01 & 3.03 & 14.18 & \begin{tabular}{|l|}
149.31 \\
\end{tabular} & 14.43 & \begin{tabular}{l|l}
10.34 \\
\end{tabular} & \\
\hline & & & Saturday & 0 & 0 & & 0.00 & 0.00 & & 0.00 & 0.00 & & 0.00 & 0.00 & & \\
\hline & & & Sunday & 0 & 0 & & 0.00 & 0.00 & & 0.00 & 0.00 & & 0.00 & 0.00 & & \\
\hline & & & Total & 5 & 15 & 0 & 531.50 & 57.00 & 9.32 & 215.05 & 15.17 & 14.18 & 746.55 & 72.17 & \begin{tabular}{|c|}
10.34 \\
\end{tabular} & NG \\
\hline \multirow[t]{4}{*}{583} & $\overline{\mathrm{K} 2}$ & Takoma-Ft Totten & Weekday & 3 & 3 & 0 & 148.40 & 15.33 & 9.68 & 53.68 & 3.35 & 16.02 & 202.08 & 18.68 & 10.82 & \\
\hline & & & Saturday & 0 & 0 & & 0.00 & 0.00 & & 0.00 & 0.00 & & 0.00 & 0.00 & & \\
\hline & & & Sunday & 0 & 0 & & 0.00 & 0.00 & & 0.00 & 0.00 & & 0.00 & 0.00 & & \\
\hline & & & Total & 15 & 15 & 0 & 742.00 & 76.67 & $\begin{array}{l}9.68 \\
\end{array}$ & 268.40 & 16.75 & 16.02 & 1010.40 & 93.42 & 10.82 & $\overline{\mathrm{S} / \mathrm{M}}$ \\
\hline \multirow[t]{4}{*}{\begin{tabular}{l|l}
800 \\
\end{tabular}} & $\mathrm{R} 1,2,5$ & Riggs Road & Weekday & 8 & 7 & 3 & 1002.68 & 65.15 & 15.39 & 200.38 & 10.08 & 19.87 & 1203.06 & 75.23 & \begin{tabular}{l|l|}
15.999 \\
\end{tabular} & \\
\hline & & & \begin{tabular}{|l|} 
Saturday \\
\end{tabular} & 2 & 2 & & 0.00 & 0.00 & & 0.00 & 0.00 & & 0.00 & 0.00 & & \\
\hline & & & Sunday & 2 & 3 & & 0.00 & 0.00 & & 0.00 & 0.00 & & 0.00 & 0.00 & & \\
\hline & & & Total & 44 & 40 & 15 & 5013.40 & 325.75 & 15.39 & 1001.90 & 50.42 & 19.87 & 6015.30 & 376.17 & \begin{tabular}{l|l}
15.99 \\
\end{tabular} & $\mathrm{NG}$ \\
\hline \multirow[t]{4}{*}{801} & R3 & Gblt-Fort Totten & Weekday & 4 & 4 & 2 & 702.95 & 42.05 & 16.72 & 133.78 & 5.32 & 25.16 & 836.73 & 47.37 & 17.66 & \\
\hline & & & \begin{tabular}{|l|} 
Saturday \\
\end{tabular} & 1 & 2 & & \begin{tabular}{l|l}
165.60 \\
\end{tabular} & 8.92 & 18.57 & 19.46 & \begin{tabular}{|c|}
1.17 \\
\end{tabular} & 16.68 & \begin{tabular}{l|l}
185.06 \\
\end{tabular} & 10.08 & \begin{tabular}{l|l|}
18.35 \\
\end{tabular} & \\
\hline & & & Sunday & 1 & 1 & & 165.60 & 8.47 & 19.56 & 13.16 & 0.80 & 16.45 & 178.76 & 9.27 & 19.29 & \\
\hline & & & Total & 22 & 23 & 10 & 3845.95 & 227.63 & 16.90 & 701.52 & 28.55 & 24.57 & 4547.47 & 256.18 & 17.75 & $\mathrm{NG}$ \\
\hline \multirow[t]{8}{*}{802} & $\mathrm{R} 4$ & Queens Chapel Rd & Weekday & 3 & 4 & 1 & 358.02 & 30.97 & 11.56 & 68.82 & 4.37 & 15.76 & 426.84 & 35.33 & 12.08 & \\
\hline & & & Saturday & 1 & 1 & & 126.36 & 9.43 & 13.40 & 9.58 & 0.67 & 14.37 & 135.94 & 10.10 & 13.46 & \\
\hline & & & Sunday & 1 & 1 & & 110.69 & 7.88 & 14.04 & 6.58 & 0.53 & 12.34 & 117.27 & 8.42 & \begin{tabular}{l|l|}
13.93 \\
\end{tabular} & \\
\hline & & & Total & 17 & 22 & 5 & 2027.15 & 172.15 & 11.78 & 360.26 & 23.03 & 15.64 & 2387.41 & 195.18 & 12.23 & $\mathrm{NG}$ \\
\hline & & All Natural Gas Buses & \begin{tabular}{|l|} 
Weekday \\
\end{tabular} & 160 & 135 & 59 & 13813.08 & 1277.63 & 10.81 & 2800.80 & 170.80 & 16.40 & 16613.88 & 1448.43 & \begin{tabular}{l|l}
11.47 \\
\end{tabular} & \\
\hline & & & Saturday & 39 & 42 & & 6679.88 & 548.60 & 12.18 & 544.23 & 33.13 & 16.43 & 7224.11 & 581.73 & 12.42 & \\
\hline & & & Sunday & 36 & 40 & & 5187.23 & 401.92 & 12.91 & 583.04 & 36.48 & 15.98 & 5770.27 & 438.40 & 13.16 & \\
\hline & & & Total & 875 & 757 & 295 & \begin{tabular}{|c|}
80932.51 \\
\end{tabular} & \begin{tabular}{|c|}
7338.68 \\
\end{tabular} & 11.03 & 15131.27 & 923.62 & 16.38 & 96063.78 & 8262.30 & 11.63 & $\overline{\mathrm{NG}}$ \\
\hline
\end{tabular}




\section{Appendix C}

\section{Fuel Consumption and Economy}




\section{WMATA Diesel Buses}

Fuel Analysis

Diesel Buse

Total Mileage

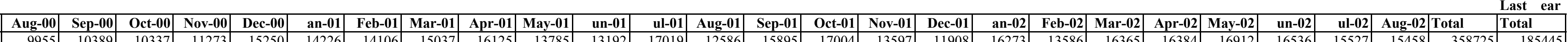

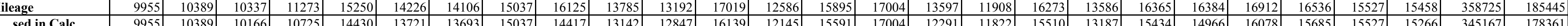

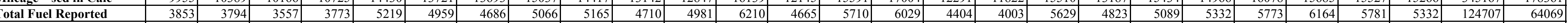

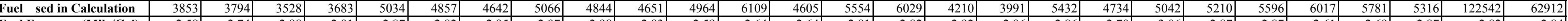

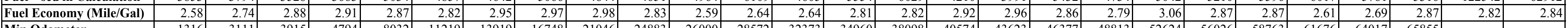

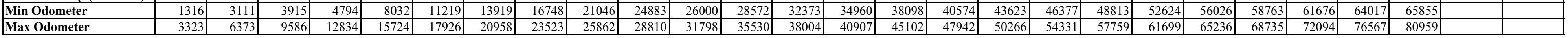
Diesel Bus 2070 tem

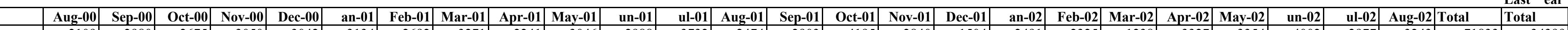

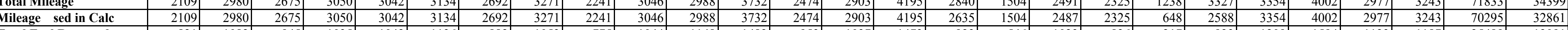

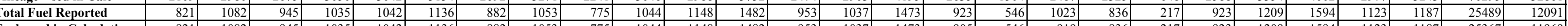

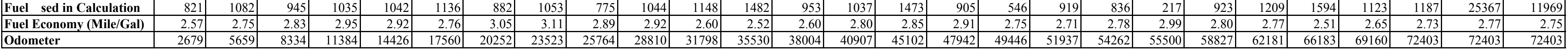
Diesel Bus 2071

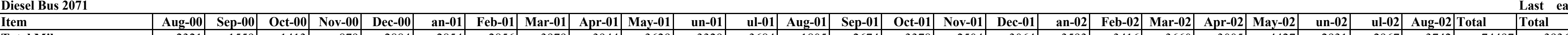

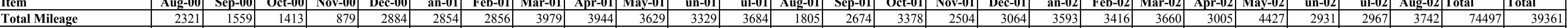

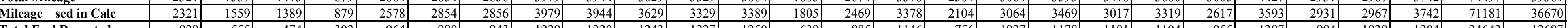

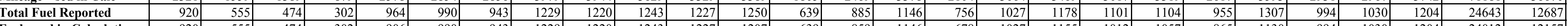

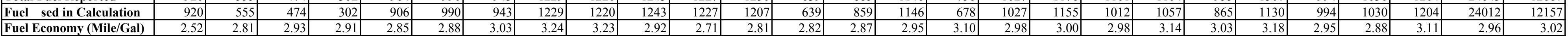

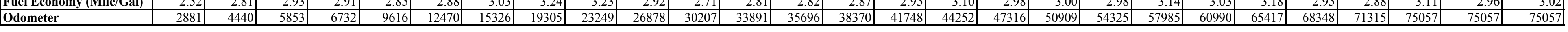
Diesel Bus 2072

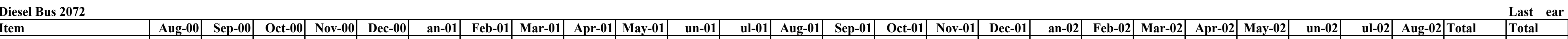

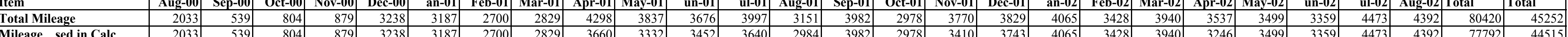

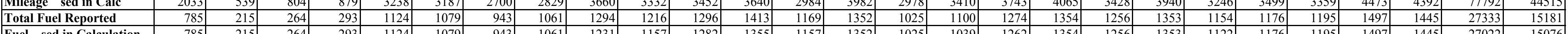

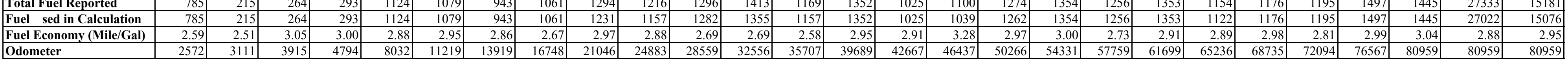
Diesel Bus 2073

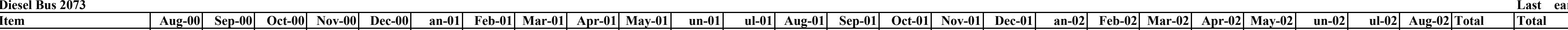

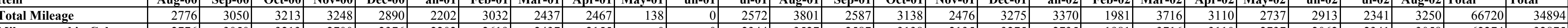

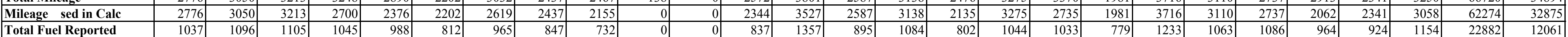

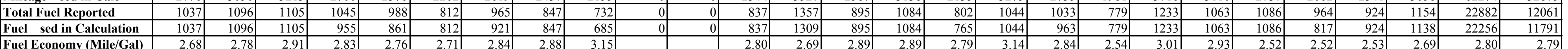

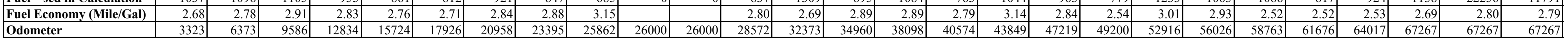
Diesel Bus 2074

Item

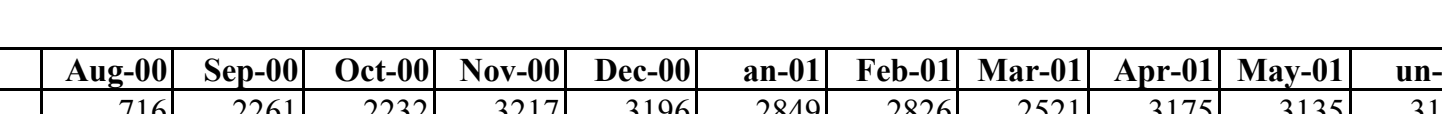

\begin{tabular}{r|r|r|r|} 
& ul-01 & Aug-01 & Sep- \\
\hline -01 & 3034 & 1355 & 3745 \\
\hline 107 & 3034 & 1355 & 3650 \\
\hline
\end{tabular}

Last ear

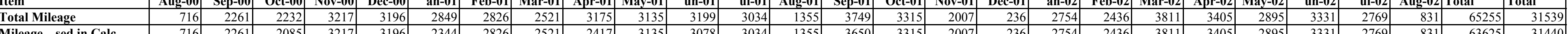

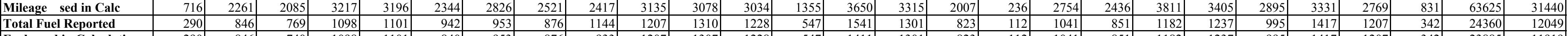

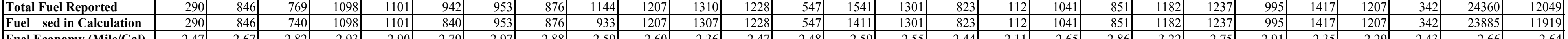

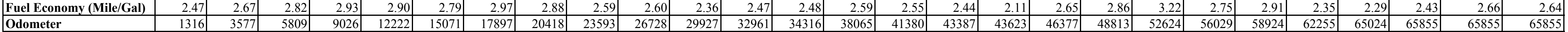




\section{WMATA CNG Buses}

\section{Fuel Analysis}

CNG/Cummins Buses Item \begin{tabular}{|l|}
\hline Tom \\
\hline Total Mileage \\
\hline
\end{tabular}

Mileage sed in Calc Total Fuel Reported

\begin{tabular}{|l|l|}
\hline Fuel sed in Calculation \\
\hline Ful
\end{tabular}

Fuel Economy (Mile/Gal)

Min Odometer

Max Odometer

CNG/Cummins Bus 2302

Item

\begin{tabular}{|l}
\hline Total Mileage \\
\hline
\end{tabular}

\begin{tabular}{l} 
Mileage sed in Calc \\
\hline
\end{tabular} \begin{tabular}{|l}
\hline Mileage sed in Calc \\
\hline Total Fuel Reported \\
\hline
\end{tabular}

\begin{tabular}{|l|}
\hline Total Fuel Reported \\
\hline Fuel sed in Calculation \\
\hline
\end{tabular}

\begin{tabular}{|l|}
\hline Fuel sed in Calculation \\
\hline Fuel Economy (Mile/Gal) \\
\hline
\end{tabular}

Odometer

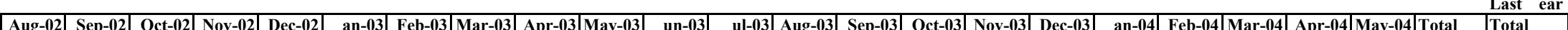

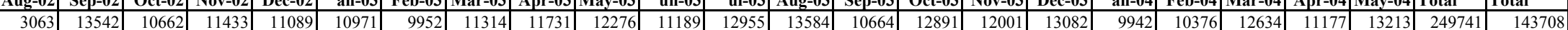

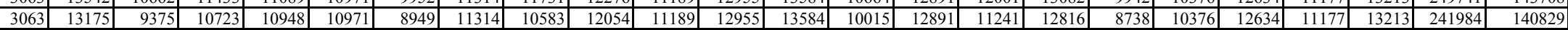

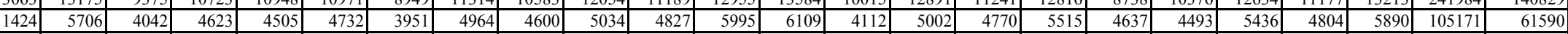

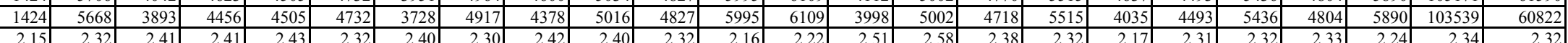

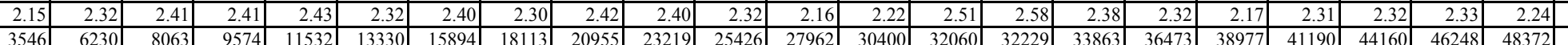

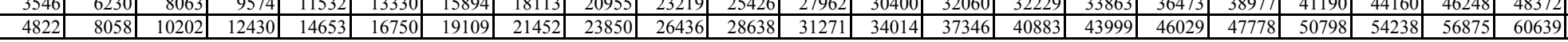

CNG/Cummins Bus 2303

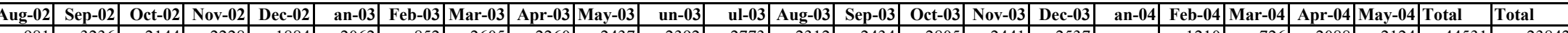

Last ear

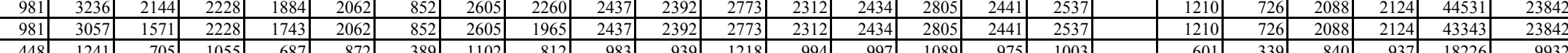

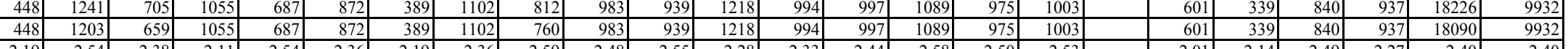
\begin{tabular}{r|r|r|r|r|r|r|r|r|r|r|r|r|r|r|r|r|r|r|r|r|r|}
2.19 & 2.54 & 2.38 & 2.11 & 2.54 & 2.36 & 2.19 & 2.36 & 2.59 & 2.48 & 2.55 & 2.28 & 2.33 & 2.44 & 2.58 & 2.50 & 2.53 & \\
44822 & 8058 & 10202 & 12430 & 14314 & 16376 & 17228 & 19833 & 22093 & 24530 & 26922 & 29695 & 32007 & 34441 & 37246 & 39687 & 42224 & \\
\end{tabular}

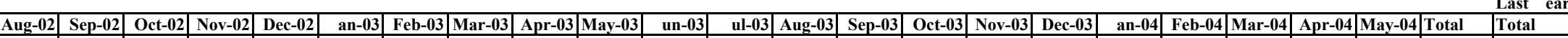

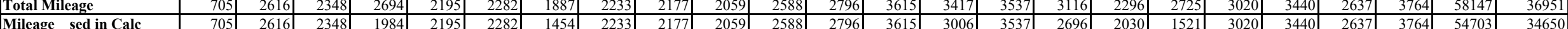

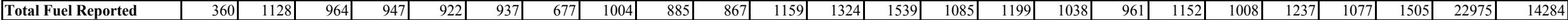

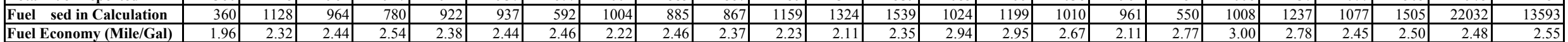

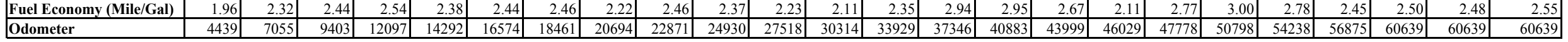
Odometer

CNG/Cummins Bus 2304 Item

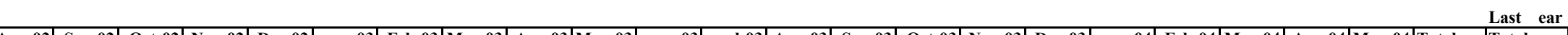
Total Mileage

Mileage sed in Calc Total Fuel Reported

Fuel sed in Calculation

Fuel Economy (Mile/Gal) \begin{tabular}{|r|r|r|r|r|r|r|r|r|r|r|r} 
Aug-02 & Sep-02 & Oct-02 & Nov-02 & Dec-02 & an-03 & Feb-03 & Mar-03 & Apr-03 & May-03 & un-03 & (ur \\
\hline 556 & 2722 & 2362 & 2451 & 2596 & 2097 & 2359 & 2343 & 2398 & 2586 & 2202 \\
\hline 55 & 2722 & 256 & 245 & 2596 & 2097 & 178 & 343 &
\end{tabular} \begin{tabular}{r|r|}
$\mathbf{u l}-\mathbf{0 3}$ & $\mathbf{A u g}-03$ \\
\hline 2633 & 2743 \\
\hline 2633 & 2743 \\
\hline
\end{tabular} \begin{tabular}{r|r|r|r|r|}
\hline $\mathbf{g - 0 3}$ & Sep-03 & Oct-03 & Nov-03 & Dec-03 \\
\hline 2743 & 2396 & 3365 & 2264 & 2909 \\
2743 & 2158 & 3365 & 2264 & 2909 \\
\hline
\end{tabular} \begin{tabular}{|r|r|r|r|r|r|r|} 
an-04 & Feb-04 & Mar-04 & Apr-04 & May-04 & Total \\
\hline 2237 & 1694 & 2658 & 2056 & 2553 & 52180 \\
\hline
\end{tabular} \begin{tabular}{|c|} 
Last ear \\
Total \\
\hline
\end{tabular}

Odometer

CNG/Cummins Bus 2307

\begin{tabular}{|l|l} 
CNG/Cummins Bus 2307 \\
\hline Item
\end{tabular}

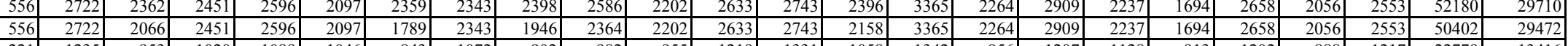

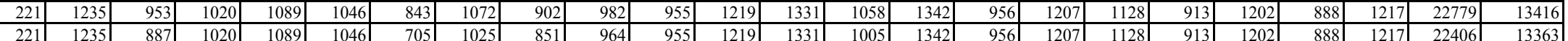

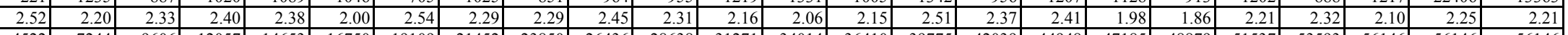

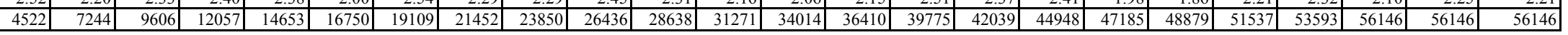

Total Mileage

Mileage sed in Calc

Total Fuel Reported

\begin{tabular}{|l|l|}
\hline Fuel sed in Calculation \\
\hline Fuel Economy (Mile/Gal)
\end{tabular}

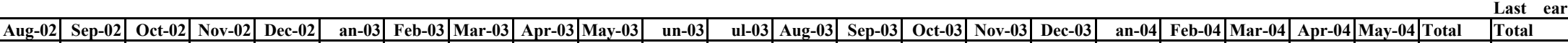
Fuel Economy (Mile/Gal) Odometer 
CNG/Cummins Bus 2309

Item

Total Mileage

Mileage sed in Calc

Total Fuel Reported

Fuel sed in Calculation

Fuel Economy (Mile/Gal)

Last ear

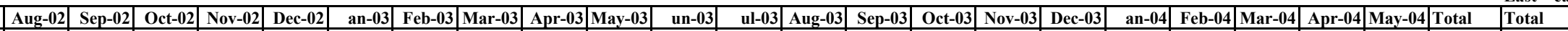
Odometer

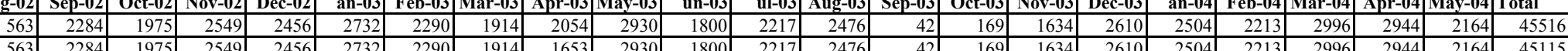

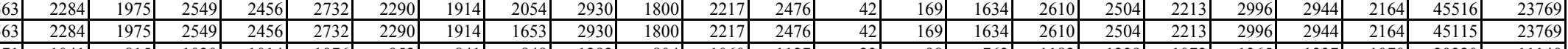

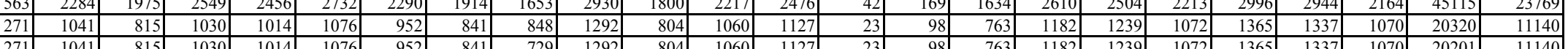

\begin{tabular}{|c|c|c|c|c|c|c|c|c|c|c|c|c|c|c|c|c|c|c|c|c|c|c|c|}
\hline 271 & 1041 & 815 & 1030 & 1014 & 1076 & 952 & 841 & 729 & 1292 & 804 & 1060 & 1127 & 23 & 98 & 763 & 1182 & 1239 & 1072 & 1365 & \begin{tabular}{|l|}
1337 \\
\end{tabular} & 1070 & 20201 & 11140 \\
\hline 08 & 2.19 & 2.42 & 2.47 & 2.42 & 2.54 & 2.41 & 2.28 & 2.27 & 2.27 & 2.24 & 2.09 & 2.20 & 1.83 & 1.72 & 2.14 & 2.21 & 2.02 & 2.06 & 2.19 & \begin{tabular}{|l|}
2.20 \\
\end{tabular} & 2.02 & 2.23 & 2.13 \\
\hline
\end{tabular}

\begin{tabular}{|c|c|c|c|c|c|c|c|c|c|c|c|c|c|c|c|c|c|c|c|c|c|c|c|}
\hline 2.08 & 2.19 & 2.42 & 2.47 & 2.42 & 2.54 & 2.41 & 2.28 & 2.27 & 2.27 & 2.24 & 2.09 & 2.20 & 1.83 & 1.72 & 2.14 & 2.21 & 2.02 & 2.06 & 2.19 & 2.20 & 2.02 & 2.23 & 2.13 \\
\hline 4341 & 6625 & 8600 & 11149 & 13605 & 16337 & 18627 & 20541 & 22595 & 25525 & 27325 & 29542 & 32018 & 32060 & 32229 & 33863 & 36473 & 38977 & 41190 & 44186 & 47130 & 49294 & 49294 & 4 \\
\hline
\end{tabular}


WMATA CNG Buses

Fuel Analysis

CNG/Deere Buses

Item

\begin{tabular}{|l}
\hline Total Mileage \\
\hline Milege \\
\hline
\end{tabular}

Mileage sed in Calc

Total Fuel Reported

\begin{tabular}{|l|l|l}
\hline Fuel sed in Calculation \\
\hline Fuel
\end{tabular}

Fuel Economy (Mile/Gal)

Min Odometer

CNG/Deere Bus 2460

Item

Total Mileage

\begin{tabular}{l} 
Total Mileage \\
\hline Mileage sed in Calc \\
\hline
\end{tabular}

\begin{tabular}{|l}
\hline Mileage sed in Calc \\
\hline Total Fuel Reported
\end{tabular}

\begin{tabular}{|l|}
\hline Total Fuel Reported \\
\hline Fuel sed in Calculation \\
\hline
\end{tabular}

Fuel Economy (Mile/Gal)

Odometer

CNG/Deere Bus 2461

\begin{tabular}{|l|}
\hline Item \\
\hline Total Mileage \\
\hline
\end{tabular}

\begin{tabular}{l} 
Mileage sed in Calc \\
\hline Tol
\end{tabular}

Total Fuel Reported

Fuel sed in Calculation

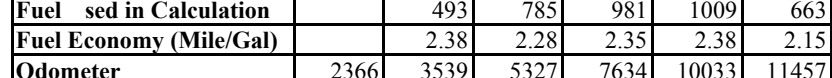

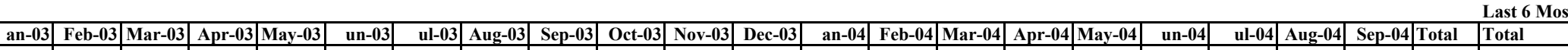

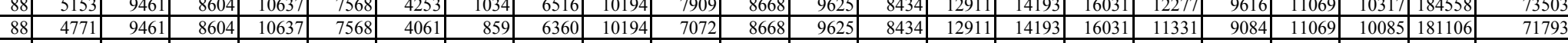

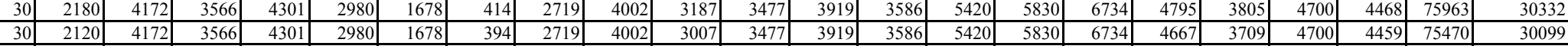
\begin{tabular}{|r|r|r|r|r|r|r|r|r|r|r|r|r|r|r|r|r|r|r|r|r|r|r|}
\hline 2.93 & 2.25 & 2.27 & 2.41 & 2.47 & 2.54 & 2.42 & 2.18 & 2.34 & 2.55 & 2.35 & 2.49 & 2.46 & 2.35 & 2.38 & 2.43 & 2.38 & 2.43 & 2.45 & 2.36 & 2.26 & 2.40 \\
\hline
\end{tabular}

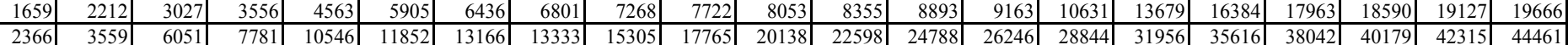

$(2.39$

CNG/Deere Bus 2462

Item \begin{tabular}{|r|r|r|r|r|r|r|r|r|r|r|r|r|r|r|r|r|r|r|r|r|r|r|r|r|} 
Last 6 Mos \\
an-03 & Feb-03 & Mar-03 & Apr-03 & May-03 & un-03 & ul-03 & Aug-03 & Sep-03 & Oct-03 & Nov-03 & Dec-03 & an-04 & Feb-04 & Mar-04 & Apr-04 & May-04 & un-04 & ul-04 & Aug-04 & Sep-04 & Total & Total & \\
\hline
\end{tabular}

Total Mileage

Mileage sed in Calc

Total Fuel Reported

Fuel sed in Calculation

Fuel Economy (Mile/Gal)

Last 6 Mos

Odometer

CNG/Deere Bus 2463

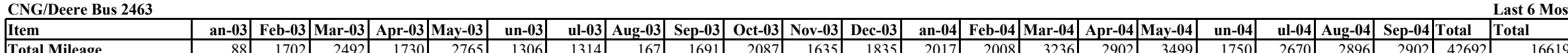

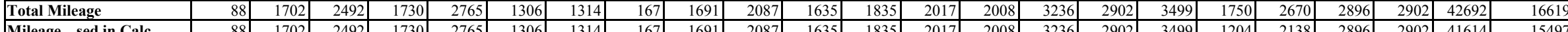

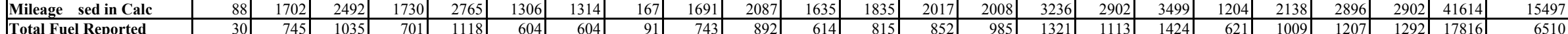
Total Fuel Reported Fuel sed in Calculation

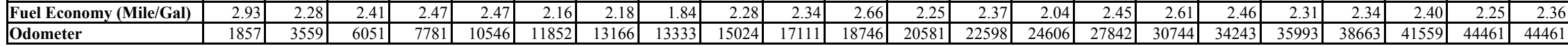

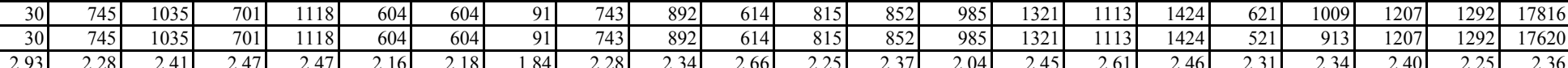

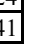


CNG/Deere Bus 2464

Item

\begin{tabular}{|l}
\hline Total Mileage \\
\hline
\end{tabular}

Mileage sed in Calc

Total Fuel Reported

Fuel sed in Calculation

\begin{tabular}{|l|} 
Fuel sed in Calculation \\
\hline Fuel Economy (Mile/Gal) \\
\hline
\end{tabular}

\begin{tabular}{l} 
Fuel Econo \\
\hline Odometer \\
\hline
\end{tabular} \begin{tabular}{|r|r|r|r|r|r|r|r|r|r|r|r|r|r|r|r|r|r|r|r|r|r|r|}
\hline an-03 & Feb-03 & Mar-03 & Apr-03 & May-03 & un-03 & ul-03 & Aug-03 & Sep-03 & Oct-03 & Nov-03 & Dec-03 & an-04 & Feb-04 & Mar-04 & Apr-04 & May-04 & un-04 & ul-04 & Aug-04 & Sep-04 & Total & Total \\
\hline
\end{tabular}

Last 6 Mos

(Mile/Gal)

\begin{tabular}{|r|r|r|r|r|r|r|r|r|r|r|r|r|r|r|r|r|r|r|r|r|r|}
7773 & 71 & 529 & 1007 & 1342 & 531 & 365 & 467 & 454 & 331 & 302 & 538 & 270 & 1468 & 3048 & 2705 & 1579 & 627 & 537 & 307 & 17251 \\
\hline 397 & 199 & 197 & 370 & 422 & 312 & 171 & 181 & 204 & 165 & 151 & 331 & 213 & 625 & 1372 & 1058 & 660 & 245 & 178 & 124 & 7575 \\
\hline
\end{tabular}

\begin{tabular}{l|r|r|r|r|r|r|r|r|r|r|r|r|}
397 & 199 & 197 & 370 & 422 & 312 & 171 & 181 & 204 & 1 \\
\hline 337 & 199 & 197 & 370 & 422 & 312 & 171 & 181 & 204 & 1.72 \\
\hline
\end{tabular}

\begin{tabular}{|r|r|r|r|r|r|r|r|r|r|r|r|r|r|r|}
165 & 151 & 331 & 213 & 625 & 1372 & 1058 & 660 & 245 & 178 & 124 & 7575 & 3750 \\
\hline 165 & 151 & 331 & 213 & 625 & 1372 & 1058 & 660 & 245 & 178 & 115 & 7506 & 3750 \\
\hline 2.01 & 2.00 & 1.63 & 1.27 & 2.35 & 2.22 & 2.56 & 2.39 & 2.56 & 3.02 & 2.67 & 2.30 & 2.22 \\
\hline
\end{tabular}

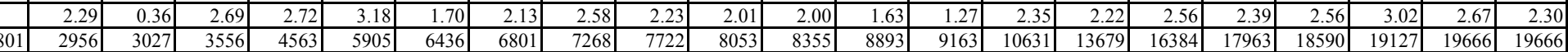




\section{Appendix D}

\section{Diesel and CNG Fuel Costs}


Average Diesel Fuel Costs at WMATA

\begin{tabular}{|l|r|r|}
\hline \multicolumn{1}{|c|}{ Period } & \multicolumn{1}{c|}{ ear } & Cost/Gal \\
\hline Sep 1st & 2001 & 0.8751 \\
\hline Sep 2nd & 2001 & 0.9434 \\
\hline Oct 1st & 2001 & 0.7654 \\
\hline Oct 2nd & 2001 & 0.7451 \\
\hline Nov 1st & 2001 & 0.6917 \\
\hline Nov 2nd & 2001 & 0.6417 \\
\hline Dec 1st & 2001 & 0.5963 \\
\hline Dec 2nd & 2001 & 0.5517 \\
\hline Jan 1st & 2002 & 0.6293 \\
\hline Jan 2nd & 2002 & 0.5936 \\
\hline Feb 1st & 2002 & 0.5813 \\
\hline Feb 2nd & 2002 & 0.6143 \\
\hline Mar 1st & 2002 & 0.7166 \\
\hline Mar 2nd & 2002 & 0.8006 \\
\hline Apr 1st & 2002 & 0.8189 \\
\hline Apr 2nd & 2002 & 0.8399 \\
\hline May 1st & 2002 & 0.8291 \\
\hline May 2nd & 2002 & 0.8333 \\
\hline Jun 1st & 2002 & 0.8136 \\
\hline Jun 2nd & 2002 & 0.7849 \\
\hline Jul 1st & 2002 & 0.8334 \\
\hline Jul 2nd & 2002 & 0.8516 \\
\hline Aug 1st & 2002 & 0.8452 \\
\hline Aug 2nd & 2002 & 0.8768 \\
\hline Average & & $\mathbf{0 . 7 5}$ \\
\hline
\end{tabular}




\section{CNG Costs at WMATA by Month}

\begin{tabular}{|r|r|r|r|r|r|}
\hline \multicolumn{1}{|c|}{ Month } & Dry Therm & Wet Therm & Total Cost & /gal & \multicolumn{1}{c|}{ DGE } \\
\hline Jul-03 & 251363 & 237853 & $177,210.86$ & 1.03 & $172,049.4$ \\
\hline Aug-03 & 269830 & 255328 & $190,226.07$ & 1.03 & $184,685.5$ \\
\hline Sep-03 & 251573 & 238052 & $177,491.03$ & 1.03 & $172,321.4$ \\
\hline Oct-03 & 230708 & 218308 & $160,908.88$ & 1.02 & $157,753.8$ \\
\hline Nov-03 & 327241 & 309653 & $281,519.11$ & 1.26 & $223,427.9$ \\
\hline Dec-03 & 162850 & 154097 & $140,124.37$ & 1.26 & $111,209.8$ \\
\hline Jan-04 & 514797 & 487128 & $439,377.74$ & 1.25 & $351,502.2$ \\
\hline Feb-04 & 255532 & 241797 & 0.00 & 1.25 & \\
\hline Mar-04 & 318142 & 301043 & $261,367.18$ & 1.25 & $209,093.7$ \\
\hline Apr-04 & 261640 & 247578 & $220,395.59$ & 1.23 & $179,183.4$ \\
\hline May-04 & 186422 & 176403 & $157,050.71$ & 1.23 & $127,683.5$ \\
\hline Jun-04 & 269768 & 255269 & $230,385.71$ & 1.25 & $184,308.6$ \\
\hline Jul-04 & 282020 & 266863 & $240,846.74$ & 1.25 & $192,677.4$ \\
\hline Aug-04 & 267806 & 253412 & $228,710.62$ & 1.25 & $182,968.5$ \\
\hline Sep-04 & 269688 & 255193 & $230,317.55$ & 1.25 & $184,254.0$ \\
\hline Total/Average & & $\mathbf{3 , 1 3 5 , 9 3 2 . 1 6}$ & $\mathbf{1 . 1 9}$ & $\mathbf{2 , 6 3 3 , 1 1 9 . 1}$ \\
\hline
\end{tabular}




\section{Appendix E}

\section{Total Maintenance Costs}


WMATA CNG Buses

Repairs Analysis

\begin{tabular}{|c|c|c|c|c|c|c|c|c|c|c|c|c|}
\hline Item & Oct-01 & Nov-01 & Dec-01 & an-02 & Feb-02 & Mar-02 & Apr-02 & \begin{tabular}{|l|} 
May-02 \\
\end{tabular} & un-02 & ul-02 & Aug-02 & Total \\
\hline Total Mileage & & 13597 & 11908 & 16273 & 13586 & 16365 & 16384 & 16912 & 16536 & 15527 & 15458 & 152546 \\
\hline Roadcalls - All & & 3 & 4 & 3 & 2 & 2 & 6 & 8 & 6 & 7 & 5 & 46 \\
\hline Roadcalls - Engine/Fuel & & 0 & 2 & 0 & 0 & 1 & 1 & 1 & 2 & 4 & 1 & 12 \\
\hline Parts Costs & & 1188.34 & 389.35 & 1067.03 & 1430.51 & 848.57 & 1187.51 & 1055.90 & 2417.63 & 2574.76 & 896.33 & 13055.93 \\
\hline Labor Hours & & 124.20 & 107.90 & 120.40 & 168.40 & 133.90 & 131.90 & 121.80 & 212.60 & 262.10 & 156.80 & 1540.00 \\
\hline \begin{tabular}{|l|l} 
Total Cost per Mile ( ) \\
\end{tabular} & & 0.544 & 0.486 & 0.436 & 0.725 & 0.461 & 0.475 & 0.423 & 0.789 & 1.010 & 0.565 & 0.590 \\
\hline Min Odometer & 38098 & 40574 & 43623 & 46377 & 48813 & 52624 & 56026 & 58763 & 61676 & 64017 & 65855 & \\
\hline Max Odometer & 45102 & 47942 & 50266 & 54331 & 57759 & 61699 & 65236 & 68735 & 72094 & 76567 & 80959 & \\
\hline
\end{tabular}

Diesel Bus 2070

\begin{tabular}{|c|c|c|c|c|c|c|c|c|c|c|c|c|}
\hline Item & Oct-01 & Nov-01 & Dec-01 & an-02 & Feb-02 & Mar-02 & Apr-02 & May-02 & un-02 & ul-02 & Aug-02 & Total \\
\hline Total Mileage & & 2840 & 1504 & 2491 & 2325 & 1238 & 3327 & 3354 & 4002 & 2977 & 3243 & 27301 \\
\hline Roadcalls - All & & 0 & 0 & 1 & 1 & 1 & 2 & 1 & 2 & 1 & 2 & 11 \\
\hline Roadcalls - Engine/Fuel & & 0 & 0 & 0 & 0 & 1 & 1 & 0 & 0 & 0 & 1 & 3 \\
\hline Parts Costs & & 305.67 & 0.00 & 47.50 & 639.24 & 78.44 & 449.96 & 429.17 & 100.96 & 331.08 & 83.61 & 2465.63 \\
\hline Labor Hours & & 27.0 & 16.0 & 21.4 & 38.5 & 20.9 & 29.1 & 25.2 & 40.0 & 38.3 & 59.2 & 315.6 \\
\hline Total Cost per Mi & & 0.583 & 0.532 & 0.449 & 1.103 & 0.907 & 0.573 & 0.504 & 0.525 & 0.754 & 0.939 & 0.668 \\
\hline Odometer & 45102 & 47942 & 49446 & 51937 & 54262 & 55500 & 58827 & 62181 & 66183 & 69160 & 72403 & 72403 \\
\hline
\end{tabular}

Diesel Bus 2071

\begin{tabular}{|c|c|c|c|c|c|c|c|c|c|c|c|c|}
\hline Item & Oct-01 & Nov-01 & Dec-01 & an-02 & Feb-02 & Mar-02 & Apr-02 & May-02 & un-02 & ul-02 & Aug-02 & Total \\
\hline Total Mileage & & 2504 & 3064 & 3593 & 3416 & 3660 & 3005 & 4427 & 2931 & 2967 & 3742 & 33309 \\
\hline Roadcalls - All & & 0 & 0 & 1 & 0 & 0 & 2 & 2 & 2 & 0 & 0 & 7 \\
\hline \begin{tabular}{|l|} 
Roadcalls - Engine/Fuel \\
\end{tabular} & & 0 & 0 & 0 & 0 & 0 & 0 & 0 & 1 & 0 & 0 & 1 \\
\hline Parts Costs & & 231.25 & 35.99 & 515.15 & 34.62 & 394.49 & 232.20 & 0.00 & 1350.67 & 807.83 & 139.62 & 3741.82 \\
\hline \begin{tabular}{|l|} 
Labor Hours \\
\end{tabular} & & 19.5 & 30.0 & 28.2 & 15.2 & 37.0 & 29.5 & 17.8 & 54.0 & 46.0 & 20.0 & 297.2 \\
\hline Total Cost pe & & 0.482 & 0.501 & 0.536 & 0.233 & 0.613 & 0.568 & 0.201 & 1.382 & 1.047 & 0.305 & 0.558 \\
\hline Odometer & 41748 & 44252 & 47316 & 50909 & 54325 & 57985 & 60990 & 65417 & 68348 & 71315 & 75057 & 75057 \\
\hline
\end{tabular}

Diesel Bus 2072

\begin{tabular}{|c|c|c|c|c|c|c|c|c|c|c|c|c|}
\hline Item & Oct-01 & Nov-01 & Dec-01 & an-02 & Feb-02 & Mar-02 & Apr-02 & May-02 & un-02 & ul-02 & Aug-02 & Total \\
\hline Total Mileage & & 3770 & 3829 & 4065 & 3428 & 3940 & 3537 & 3499 & 3359 & 4473 & 4392 & 38292 \\
\hline Roadcalls - All & & 1 & 2 & 0 & 0 & 0 & 1 & 1 & 0 & 3 & 1 & 9 \\
\hline Roadcalls - Eng & & 0 & 1 & 0 & 0 & 0 & 0 & 1 & 0 & 2 & 0 & 4 \\
\hline Parts C & & 345.55 & 104.62 & 4.38 & 225.14 & 254.88 & 186.42 & 86.68 & 312.46 & 376.43 & 95.99 & 1992.55 \\
\hline Labor Hours & & 20.0 & 27.1 & 19.5 & 26.7 & 19.2 & 20.8 & 27.2 & 43.5 & 41.5 & 17.3 & 262.8 \\
\hline Total Cost per Mile ( ) & & 0.357 & 0.381 & 0.241 & 0.455 & 0.308 & 0.347 & 0.413 & 0.741 & 0.548 & 0.219 & 0.395 \\
\hline Odometer & 42667 & 46437 & 50266 & 54331 & 57759 & 61699 & 65236 & 68735 & 72094 & 76567 & 80959 & 80959 \\
\hline
\end{tabular}

Diesel Bus 2073

\begin{tabular}{|c|c|c|c|c|c|c|c|c|c|c|c|c|}
\hline Item & Oct-01 & Nov-01 & Dec-01 & an-02 & Feb-02 & Mar-02 & Apr-02 & May-02 & un-02 & ul-02 & Aug-02 & Total \\
\hline \begin{tabular}{|l} 
Total Mileage \\
\end{tabular} & & 2476 & 3275 & 3370 & 1981 & 3716 & 3110 & 2737 & 2913 & 2341 & 3250 & 29169 \\
\hline Roadcalls - All & & 2 & 1 & 1 & 1 & 0 & 0 & 2 & 2 & 2 & 0 & 11 \\
\hline Roadcalls - Engi & & 0 & 1 & 0 & 0 & 0 & 0 & 0 & 7 & 1 & 0 & 3 \\
\hline \begin{tabular}{|l|} 
Parts Costs \\
\end{tabular} & & 0.00 & 248.74 & 500.00 & 272.43 & 90.76 & 126.60 & 540.05 & 548.92 & 215.81 & 297.00 & 2840.31 \\
\hline Labor Hours & & 21.5 & 32.1 & 38.5 & 28.0 & 36.5 & 34.0 & 30.9 & 59.1 & 46.3 & 16.0 & 342.9 \\
\hline Total Cost per Mile ( ) & & 0.434 & 0.566 & 0.720 & 0.844 & 0.516 & 0.587 & 0.762 & 1.203 & 1.081 & 0.338 & 0.685 \\
\hline Odometer & 38098 & 40574 & 43849 & 47219 & 49200 & 52916 & 56026 & 58763 & 61676 & 64017 & 67267 & 67267 \\
\hline
\end{tabular}

Diesel Bus 2074

\begin{tabular}{|c|c|c|c|c|c|c|c|c|c|c|c|c|}
\hline Item & Oct-01 & Nov-01 & Dec-01 & an-02 & Feb-02 & Mar-02 & Apr-02 & May-02 & un-02 & ul-02 & Aug-02 & Total \\
\hline Total Mileage & & 2007 & 236 & 2754 & 2436 & 3811 & 3405 & 2895 & 3331 & 2769 & 831 & 24475 \\
\hline Roadcalls - All & & 0 & 1 & 0 & 0 & 1 & 1 & 2 & 0 & 1 & 2 & 8 \\
\hline \begin{tabular}{|l|} 
Roadcalls - Engine/Fuel \\
\end{tabular} & & 0 & 0 & 0 & 0 & 0 & 0 & 0 & 0 & 1 & 0 & 1 \\
\hline \begin{tabular}{|l|} 
Parts Costs \\
\end{tabular} & & 305.87 & 0.00 & 0.00 & 259.08 & 30.00 & 192.33 & 0.00 & 104.62 & 843.61 & 280.11 & 2015.62 \\
\hline \begin{tabular}{|l} 
Labor Hours \\
\end{tabular} & & 36.2 & 2.7 & 12.8 & 60.0 & 20.3 & 18.5 & 20.7 & 16.0 & 90.0 & 44.3 & 321.5 \\
\hline \begin{tabular}{|l|l} 
Total Cost per Mile ( ) \\
\end{tabular} & & 1.054 & 0.572 & 0.232 & 1.338 & 0.274 & 0.328 & 0.358 & 0.272 & 1.930 & 3.003 & 0.739 \\
\hline Odometer & 41380 & 43387 & 43623 & 46377 & 48813 & 52624 & 56029 & 58924 & 62255 & 65024 & 65855 & 65855 \\
\hline
\end{tabular}




\section{WMATA CNG Buses}

\section{Repairs Analysis}

CNG/Cummins Buses Item

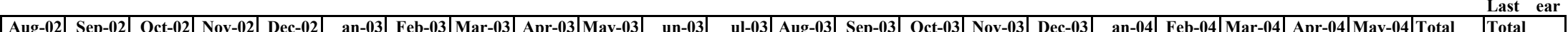

Total Mileage

\begin{tabular}{|l|} 
Roadcalls - All \\
\hline Roadcalls - Engine/Fuel \\
\hline
\end{tabular}

Parts Costs

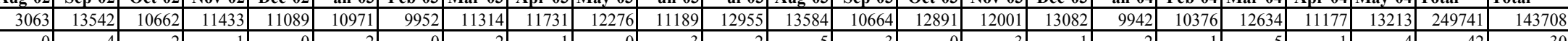

Labor Hours

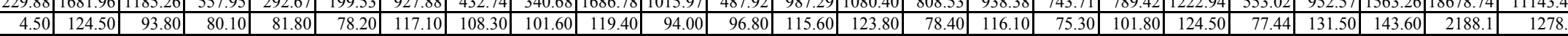

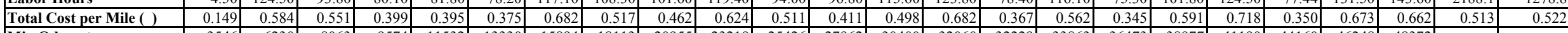

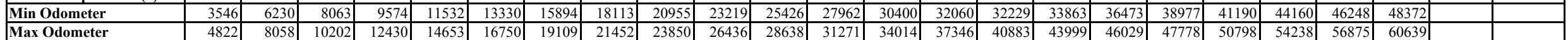

CNG/Cummins Bus 2302

Item

Last ear

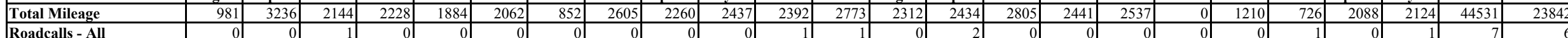

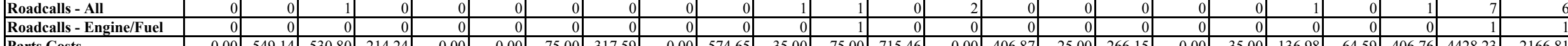
Parts Costs

Labor Hours

Total Cost per Mile ( )

Odometer

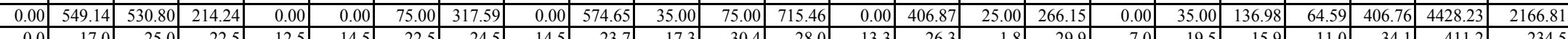

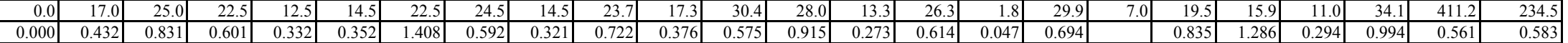

CNG/Cummins Bus 2303

Item

\begin{tabular}{l|r|r|r|r|r|r|r|r|r|r|r|r|r|r|r|r|r|r|r|r|r|r|r|r|r|r|r|r|r|r|r|r|}
\hline 4822 & 8058 & 10202 & 12430 & 14314 & 16376 & 17228 & 19833 & 22093 & 24530 & 26922 & 29695 & 32007 & 34441 & 37246 & 39687 & 42224 & 42224 & 43434 & 44160 & 46248 & 48372 & 48372 & 48372 \\
\hline
\end{tabular}

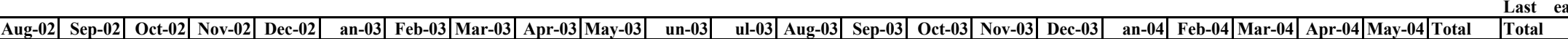

Total Mileage

Roadcalls - Engine/Fuel

Parts Costs

Labor Hours

Total Cost per Mile ( )

Odometer

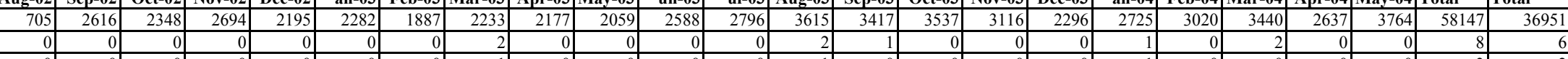

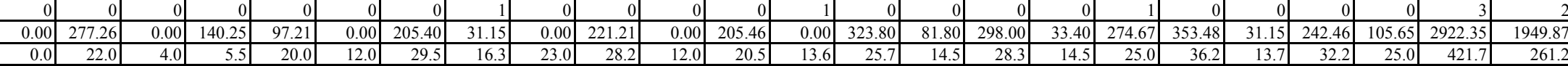

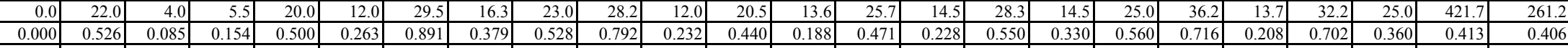
\begin{tabular}{l|l|l|l|l|l|l|l|l|l|l|l|l|l|l|l|l|l|l|l|l|l|l|l|}
\hline 4439 & 7055 & 9403 & 12097 & 14292 & 16574 & 18461 & 20694 & 22871 & 24930 & 27518 & 30314 & 33929 & 37346 & 40883 & 43999 & 46029 & 47778 & 50798 & 54238 & 56875 & 60639 & 60639 & 60639 \\
\hline
\end{tabular}

CNG/Cummins Bus 2304

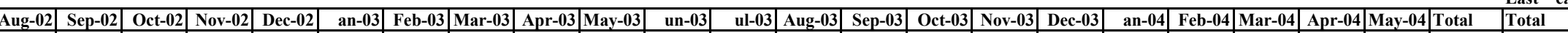

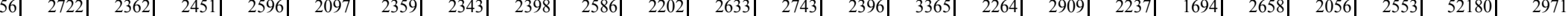
Roadcalls - All

Roadcalls - Engine/Fuel

Parts Costs

Labor Hours

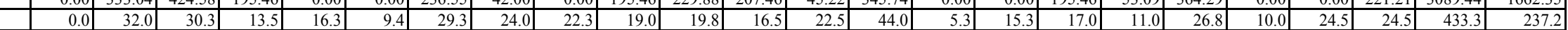

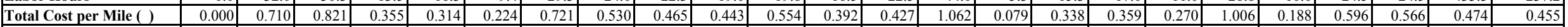

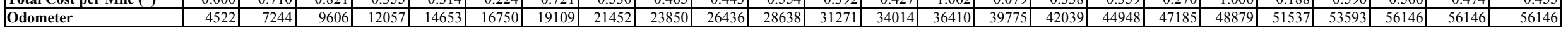

CNG/Cummins Bus 2307

Item

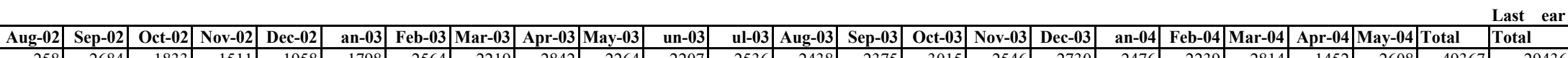
Total Mileage Roadcalls - All

Roadcalls - Engine/Fuel Parts Costs

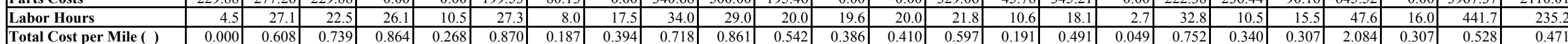

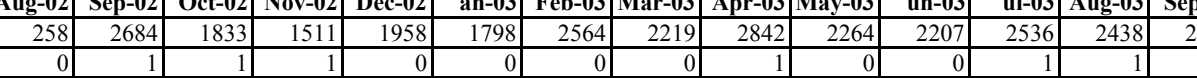

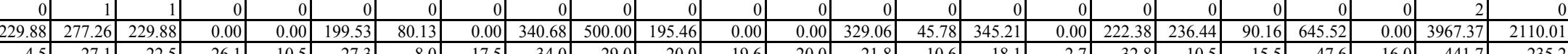

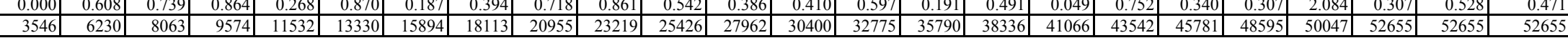


CNG/Cummins Bus 2309 Item

Total Mileag

Roadcalls - All

Roadcalls - Engine/Fuel

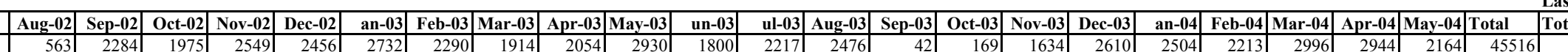

Last ear

Labor Hours

Total Cost per Mile ( )

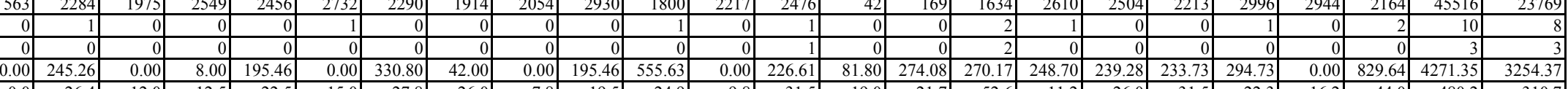

\begin{tabular}{r|r|r|r|}
\hline 2284 & 1975 & 2549 & \\
\hline 1 & 0 & 0 & \\
\hline 0 & 0 & 0 & \\
\hline
\end{tabular}

\begin{tabular}{|r|r|r|r|r|r|r|r|r|r|r|r|r|r|r|r|r|r|r|r|r|}
2456 & 2732 & 2290 & 1914 & 2054 & 2930 & 1800 & 2217 & 2476 & 42 & 169 & 1634 & 2610 \\
\hline 0 & 1 & 0 & 0 & 0 & 0 & 1 & 0 & 1 & 0 & 0 & 2 & 1 \\
\hline 0 & 0 & 0 & 0 & 0 & 0 & 0 & 0 & 1 & 0 & 0 & 2 & 0 \\
\hline 95.46 & 0.00 & 330.80 & 42.00 & 0.00 & 195.46 & 555.63 & 0.00 & 226.61 & 81.80 & 274.08 & 270.17 & 248.70 \\
\hline
\end{tabular}

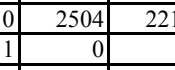

Odometer

\begin{tabular}{|c|c|c|c|c|c|c|c|c|c|c|c|c|c|c|c|c|c|c|c|c|c|c|c|}
\hline 0.0 & 26.4 & 12.0 & 12.5 & 22.5 & 15.0 & 27.8 & 26.0 & 7.8 & 19.5 & 24.9 & 9.8 & 31.5 & 19.0 & 21.7 & 52.6 & 11.2 & 26.0 & 31.5 & 22.3 & 16.2 & 44.0 & 480.2 & 310.7 \\
\hline .000 & 0.685 & 0.304 & 0.248 & \begin{tabular}{|c|c|}
0.538 \\
\end{tabular} & 0.275 & 0.751 & 0.701 & |0.190 & 0.399 & 1.000 & 0.221 & 0.728 & 24.567 & 8.042 & 1.775 & 0.310 & 0.615 & \begin{tabular}{|c|c|}
0.817 \\
\end{tabular} & 0.471 & 0.275 & 1.400 & 0.621 & 0.790 \\
\hline
\end{tabular}

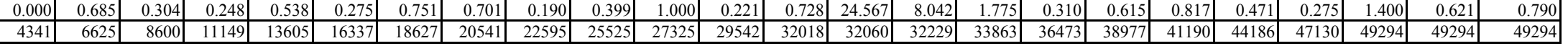




\section{WMATA CNG Buses}

\section{Repairs Analysis}

CNG/Deere Buses

Last 6 Mos

Item

\begin{tabular}{|l} 
Total Mileage \\
\hline Roadcalls - All \\
\hline
\end{tabular}

\begin{tabular}{|l} 
Roadcalls - All \\
\hline Roadcalls - Engine/Fue \\
\hline
\end{tabular}

\begin{tabular}{|l|}
\hline Roadcalls - Engine/Fuel \\
\hline Parts Costs \\
\hline Lar
\end{tabular}

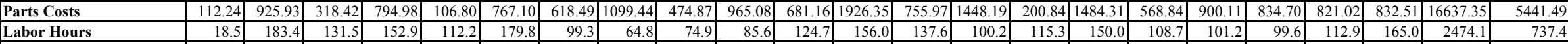

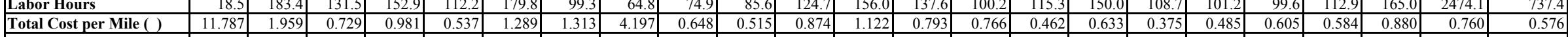

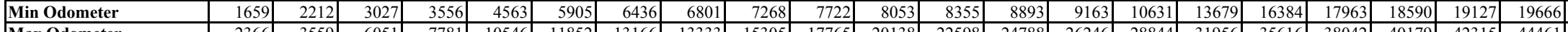

\begin{tabular}{|l|r|r|r|r|r|r|r|r|r|r|r|r|r|r|r|r|r|r|r|r|r|}
\hline Max Odometer & 2366 & 3559 & 6051 & 7781 & 10546 & 11852 & 13166 & 13333 & 15305 & 17765 & 20138 & 22598 & 24788 & 26246 & 28844 & 31956 & 35616 & 38042 & 40179 & 42315 & 44461 \\
\hline
\end{tabular}

\section{CNG/Deere Bus 2460}

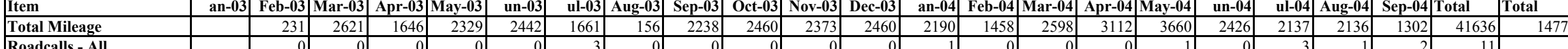

Roadcalls - All

Roadcalls - Engine/Fuel

Roadcalls -

\begin{tabular}{|l|l|l}
\hline Parts Costs \\
\hline Labor Hours \\
\hline Total Cost per Min
\end{tabular}

Labor Hours

Odometer

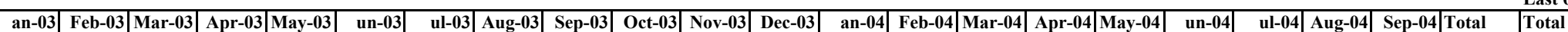
\begin{tabular}{|l|l|l|l|l|l|l|l|l|l|l|l|l|l|l|l|l|l|l|l|l|l|}
\hline 88 & 5153 & 9461 & 8604 & 10637 & 7568 & 4253 & 1034 & 6516 & 10194 & 7909 & 8668 & 9625 & 8434 & 12911 & 14193 & 16031 & 12277 & 9616 & 11069 & 10317 & 184558 \\
\hline
\end{tabular}

CNG/Deere Bus 2461

\begin{tabular}{|l|}
\hline Item \\
\hline Total Milea \\
\hline Roadcals - AII \\
\hline
\end{tabular}

\begin{tabular}{l} 
Total Mileage \\
\hline Roadcalls - All \\
\hline
\end{tabular}

Roadcalls - Engine/Fuel

Parts Costs

Parts Costs

\begin{tabular}{|l|}
\hline Labor Hours \\
\hline Total Cost per Mile ( ) \\
\hline
\end{tabular}

(2)

\begin{tabular}{l|l}
\hline & \\
\hline & 229.8 \\
\hline & \\
\hline
\end{tabular}

Odometer

CNG/Deere Bus 2462

Item

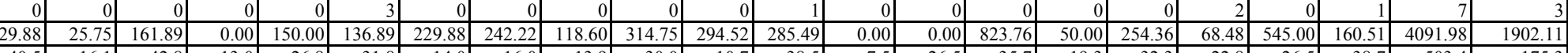

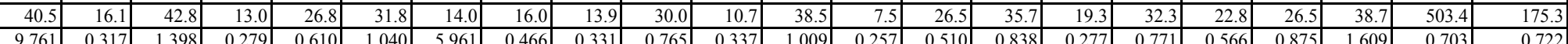

Total Mileage

Roadcalls - All

Roadcalls - Engine/Fuel

Parts Costs

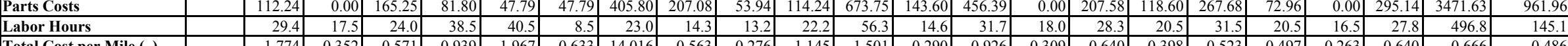

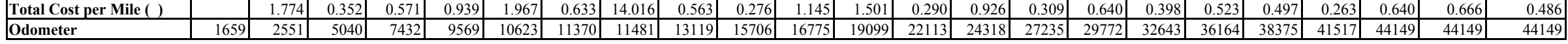

CNG/Deere Bus 2463

Item

\begin{tabular}{r|r|r|r|r|r|r|r|r|r|r|r|r|r|r|r|r|r|r|r|r|r|r|r|} 
an-03 & Feb-03 & Mar-03 & Apr-03 & May-03 & un-03 & ul-03 & Aug-03 & Sep-03 & Oct-03 & Nov-03 & Dec-03 & an-04 & Feb-04 & Mar-04 & Apr-04 & May-04 & un-04 & ul-04 & Aug-04 & Sep-04 & Total \\
\hline
\end{tabular}

Last 6 Mo

Total Mileage

Roadcalls - All

Roadcalls - Engine/Fuel

Parts Costs

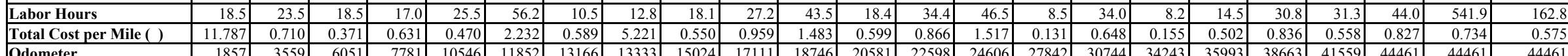
\begin{tabular}{|r|r|r|r|}
\hline 1173 & 1788 & 2 \\
\hline 0 & 2 & \\
0 & 2 & \\
\hline 320.53 & 62.79 & 175.25 \\
\hline 41.5 & 57.9 & 3 \\
\hline 2.042 & 1.654 & 0.7 \\
\hline 3539 & 5327 & 7 \\
\multicolumn{4}{|l}{} \\
\hline Feb-03 & Mar-03 & $\mathbf{A p r}$ \\
\hline 892 & 2489 & 2 \\
\hline 1 & 0 & \\
\hline 0 & 0 & \\
\hline 112.24 & 0.00 & 165.25 \\
\hline 29.4 & 17.5 & 2 \\
\hline 1.774 & 0.352 & 0.571 \\
2551 & 5040 & 7
\end{tabular}

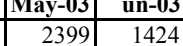

\begin{tabular}{|r|r|r|}
\hline 0 & 235 & \\
\hline 0 & 0 & \\
\hline 0 & 0 & \\
\hline 0.00 & 231.88 & \\
\hline 13.0 & 7.0 & \\
\hline
\end{tabular}

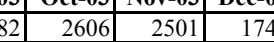

\begin{tabular}{r|r|r|r|r|r|r}
\hline 1866 & 2493 & 2692 & 2594 & 3290 \\
\hline 0 & 0 & 1 & 0 & \\
\hline 0 & 0 & 0 & 0 & \\
\hline 65.00 & 269.75 & 200.62 & 30.00 & 164.64 \\
\hline & 0.707 & 0.309 & 0.767 & 0.574 & 0.326 \\
\hline 20894 & 23387 & 26079 & 28673 & 31969 \\
\hline
\end{tabular}

\begin{tabular}{|c|c|c|c|c|c|}
\hline & & & & & \\
\hline 3001 & 1971 & 2358 & 2942 & 39875 & 16162 \\
\hline 0 & 0 & 0 & 0 & 8 & 1 \\
\hline 0 & 0 & 0 & 0 & 6 & 0 \\
\hline 0.00 & 0.00 & 226.02 & 177.66 & 3058.65 & 598.32 \\
\hline 0.0 & 8.5 & 12.6 & 38.0 & 503.6 & 106.5 \\
\hline 0.000 & 0.216 & 0.363 & 0.706 & 0.708 & 0.366 \\
\hline 34970 & 36941 & 39299 & 42241 & 42241 & 42241 \\
\hline
\end{tabular}

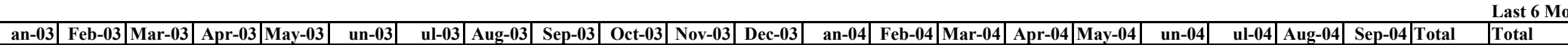

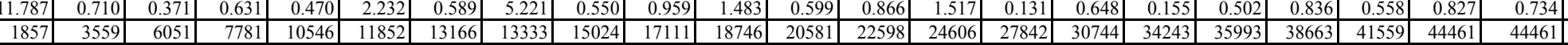

Last 6 Mo 

CNG/Deere Bus 2464 Item
Total Mileage
Roadcils-All

Roadcalls - All

Roadcalls - Engine/Fuel

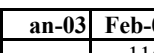

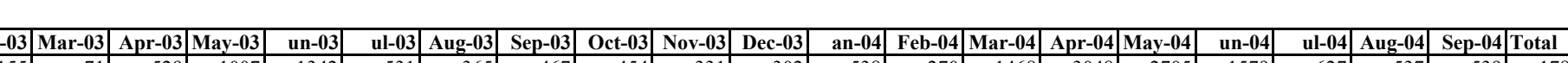

Last 6 Mos an-03

\begin{tabular}{r|r|r|r|}
\hline 1 & 0 & 1 & \\
\hline 0 & 0 & 1 & \\
\hline 8 & 229.88 & 50.57 & 0.0 \\
\hline 5 & 21.5 & 36.0 & 16 \\
\hline 9 & 18.379 & 3.498 & 0.81 \\
\hline & 3027 & 3556 &
\end{tabular}

\begin{tabular}{r|r|}
\hline 007 & 1342 \\
\hline 0 & \\
\hline 0 & 0 \\
\hline 0.00 & 35.0 \\
\hline 16.5 & 13 \\
\hline 0.819 & 0.52 \\
\hline 4563 & 5905 \\
\hline
\end{tabular}

\begin{tabular}{|r|r|r|}
\hline 0 & 531 & \\
\hline 0 & 1 & \\
\hline 00 & 184.68 & 0.00 \\
\hline .5 & 35.5 & \\
\hline 29 & 3.691 & 1.0 \\
\hline & 643 &
\end{tabular}

\begin{tabular}{|r|r|r|r|r|r|r|r|r|r|r|r|r|r|r|r|r|r|r|}
\hline 05 & Sep-03 & Oct-03 & Nov-03 & Dec-03 & an-04 & Feb-04 & Mar-04 & Apr-04 & May-04 & un-04 & ul-04 & Aug-04 & Sep-04 & Total & Total \\
\hline 0 & 467 & 454 & 331 & 302 & 538 & 270 & 1468 & 3048 & 2705 & 1579 & 627 & 537 & 539 & 17865 & 9035 \\
\hline 0 & 0 & 0 & 0 & 0 & 0 & 0 & 1 & 0 & 0 & 0 & 0 & 0 & 0 & 4 & 0 \\
\hline 00 & 0.00 & 0 & 0 & 0 & 0 & 0 & 0 & 0 & 0 & 0 & 0 & 0 & 0 & 2 & 0 \\
\hline 8.0 & 9.0 & 18.8 & 0.00 & 195.81 & 234.88 & 0.00 & 0.22 & 242.77 & 102.00 & 224.06 & 0.00 & 0.00 & 0.00 & 1759.75 & 568.83 \\
\hline & 0.964 & 2.137 & 0.982 & 2.701 & 25.0 & 4.5 & 25.0 & 22.8 & 42.5 & 22.9 & 17.0 & 26.0 & 16.5 & 428.4 & 147.7 \\
\hline
\end{tabular}

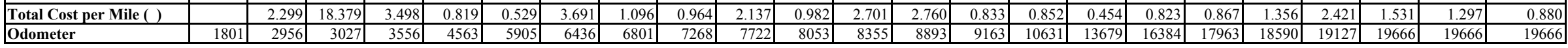




\section{Appendix F}

Maintenance Costs Broken Down by Vehicle System 
Fleet Summary Statistics

$12 / 13 / 2004$

Washington Metropolitan Area Transit Authority (WMATA)

Diesel Study Group

Fleet Operations and Economics

\begin{tabular}{|c|c|c|}
\hline & \begin{tabular}{|l} 
Diesel \\
All Data \\
\end{tabular} & \begin{tabular}{|l} 
Diesel \\
Last ear
\end{tabular} \\
\hline Number of Vehicles & 5 & 5 \\
\hline Period Used for Fuel and Oil Op Anaysis & $8 / 00-8 / 02$ & $9 / 01-8 / 02$ \\
\hline Total Number of Months in Period & 25 & 12 \\
\hline Fuel and Oil Analysis Base Fleet Mileage & 345,167 & 178,361 \\
\hline Period Used for Maintenance Op Analysis & $11 / 01-8 / 02$ & $11 / 01-8 / 02$ \\
\hline Total Number of Months in Period & 10 & 10 \\
\hline Maintenance Analysis Base Fleet Mileage & 152,546 & 152,546 \\
\hline Average Monthly Mileage per Vehicle & 2,940 & 3,143 \\
\hline Fleet Diesel Usage in Gal. & 122,542 & 62,912 \\
\hline Representative Fleet MPG (energy equiv) & 2.82 & 2.84 \\
\hline Diesel Cost per gallon & 1.33 & 1.33 \\
\hline Fuel Cost per Mile & 0.472 & 0.469 \\
\hline Total Scheduled Repair Cost per Mile & 0.273 & 0.273 \\
\hline Total Unscheduled Repair cost per Mile & 0.318 & 0.318 \\
\hline Total Maintenance Cost per Mile & 0.590 & 0.590 \\
\hline Total Operating Cost per Mile & 1.063 & 1.059 \\
\hline
\end{tabular}

Maintenance Costs

\begin{tabular}{|c|c|c|}
\hline & $\begin{array}{l}\text { Diesel } \\
\text { All Data }\end{array}$ & $\begin{array}{l}\text { Diesel } \\
\text { Last ear }\end{array}$ \\
\hline Fleet Mileage & 152,546 & 152,546 \\
\hline $\begin{array}{l}\text { Total Parts Cost } \\
\text { Total Labor Hours } \\
\text { Average Labor Cost } \\
(@ \$ 50.00 \text { per hour) }\end{array}$ & $\begin{array}{r}13,055.93 \\
1540.0 \\
77,000.00\end{array}$ & $\begin{array}{r}13,055.93 \\
1540.0 \\
77,000.00\end{array}$ \\
\hline Total Maintenance Cost & $90,055.93$ & $90,055.93$ \\
\hline Total Maintenance Cost per Bus & $18,011.19$ & $18,011.19$ \\
\hline Total Maintenance Cost per Mile & 0.590 & 0.590 \\
\hline
\end{tabular}


Breakdown of Maintenance Costs by Vehicle System

\begin{tabular}{|c|c|c|}
\hline & $\begin{array}{l}\text { Diesel } \\
\text { All Data }\end{array}$ & \begin{tabular}{|l|} 
Diesel \\
Last ear \\
\end{tabular} \\
\hline Fleet Mileage & 152,546 & 152,546 \\
\hline \multicolumn{3}{|c|}{$\begin{array}{l}\text { Total Engine/Fuel-Related Systems } \\
\text { (ATA VMRS 30, 31, 32, 33, 41, 42, 43, 44, 45) }\end{array}$} \\
\hline Parts Cost & $5,114.48$ & $5,114.48$ \\
\hline Labor Hours & 268.4 & 268.4 \\
\hline Average Labor Cost & $13,420.00$ & $13,420.00$ \\
\hline Total Cost (for system) & $18,534.48$ & $18,534.48$ \\
\hline Total Cost (for system) per Bus & $3,706.90$ & $3,706.90$ \\
\hline Total Cost (for system) per Mile & 0.1215 & 0.1215 \\
\hline \multicolumn{3}{|c|}{ Exhaust System Repairs (ATA VMRS 43) } \\
\hline Parts Cost & 420.06 & 420.06 \\
\hline Labor Hours & 17.0 & 17.0 \\
\hline Average Labor Cost & 850.00 & 850.00 \\
\hline Total Cost (for system) & $1,270.06$ & $1,270.06$ \\
\hline Total Cost (for system) per Bus & 254.01 & 254.01 \\
\hline Total Cost (for system) per Mile & $\mathbf{0 . 0 0 8 3}$ & 0.0083 \\
\hline \multicolumn{3}{|c|}{ Fuel System Repairs (ATA VMRS 44) } \\
\hline Parts Cost & 766.01 & 766.01 \\
\hline Labor Hours & 10.2 & 10.2 \\
\hline Average Labor Cost & 510.00 & 510.00 \\
\hline Total Cost (for system) & $1,276.01$ & $1,276.01$ \\
\hline Total Cost (for system) per Bus & 255.20 & 255.20 \\
\hline Total Cost (for system) per Mile & 0.0084 & 0.0084 \\
\hline \multicolumn{3}{|c|}{ Power Plant (Engine) Repairs (ATA VMRS 45) } \\
\hline Parts Cost & $1,301.90$ & $1,301.90$ \\
\hline Labor Hours & 61.7 & 61.7 \\
\hline Average Labor Cost & $3,085.00$ & $3,085.00$ \\
\hline Total Cost (for system) & $4,386.90$ & $4,386.90$ \\
\hline Total Cost (for system) per Bus & 877.38 & 877.38 \\
\hline Total Cost (for system) per Mile & $\mathbf{0 . 0 2 8 8}$ & $\mathbf{0 . 0 2 8 8}$ \\
\hline \multicolumn{3}{|c|}{$\begin{array}{l}\text { Electrical System Repairs (ATA VMRS 30-Electrical General, } \\
\text { 31-Charging, 32-Cranking, 33-Ignition) }\end{array}$} \\
\hline Parts Cost & $1,457.83$ & $1,457.83$ \\
\hline Labor Hours & 22.5 & 22.5 \\
\hline Average Labor Cost & $1,125.00$ & $1,125.00$ \\
\hline Total Cost (for system) & $2,582.83$ & $2,582.83$ \\
\hline Total Cost (for system) per Bus & 516.57 & 516.57 \\
\hline Total Cost (for system) per Mile & 0.0169 & 0.0169 \\
\hline
\end{tabular}


Breakdown of Maintenance Costs by Vehicle System (continued)

\begin{tabular}{|c|c|c|}
\hline & $\begin{array}{l}\text { Diesel } \\
\text { All Data }\end{array}$ & $\begin{array}{l}\text { Diesel } \\
\text { Last ear }\end{array}$ \\
\hline \multicolumn{3}{|c|}{ Air Intake System Repairs (ATA VMRS 41) } \\
\hline Parts Cost & 123.15 & 123.15 \\
\hline Labor Hours & 0.0 & 0.0 \\
\hline Average Labor Cost & 0.00 & 0.00 \\
\hline Total Cost (for system) & 123.15 & 123.15 \\
\hline Total Cost (for system) per Bus & 24.63 & 24.63 \\
\hline Total Cost (for system) per Mile & 0.0008 & 0.0008 \\
\hline \multicolumn{3}{|c|}{ Cooling System Repairs (ATA VMRS 42) } \\
\hline Parts Cost & $1,045.53$ & $1,045.53$ \\
\hline Labor Hours & 157.0 & 157.0 \\
\hline Average Labor Cost & $7,850.00$ & $7,850.00$ \\
\hline Total Cost (for system) & $8,895.53$ & $8,895.53$ \\
\hline Total Cost (for system) per Bus & $1,779.11$ & $1,779.11$ \\
\hline Total Cost (for system) per Mile & $\mathbf{0 . 0 5 8 3}$ & $\mathbf{0 . 0 5 8 3}$ \\
\hline \multicolumn{3}{|c|}{ Hydraulic System Repairs (ATA VMRS 65) } \\
\hline Parts Cost & 207.22 & 207.22 \\
\hline Labor Hours & 18.0 & 18.0 \\
\hline Average Labor Cost & 900.00 & 900.00 \\
\hline Total Cost (for system) & $1,107.22$ & $1,107.22$ \\
\hline Total Cost (for system) per Bus & 221.44 & 221.44 \\
\hline Total Cost (for system) per Mile & 0.0073 & 0.0073 \\
\hline \multicolumn{3}{|c|}{ General Air System Repairs (ATA VMRS 10) } \\
\hline Parts Cost & 399.63 & 399.63 \\
\hline Labor Hours & 42.1 & 42.1 \\
\hline Average Labor Cost & $2,105.00$ & $2,105.00$ \\
\hline Total Cost (for system) & $2,504.63$ & $2,504.63$ \\
\hline Total Cost (for system) per Bus & 500.93 & 500.93 \\
\hline Total Cost (for system) per Mile & 0.0164 & 0.0164 \\
\hline \multicolumn{3}{|c|}{ Brake System Repairs (ATA VMRS 13) } \\
\hline Parts Cost & $2,523.91$ & $2,523.91$ \\
\hline Labor Hours & 153.3 & 153.3 \\
\hline Average Labor Cost & $7,665.00$ & $7,665.00$ \\
\hline Total Cost (for system) & $10,188.91$ & $10,188.91$ \\
\hline Total Cost (for system) per Bus & $2,037.78$ & $2,037.78$ \\
\hline Total Cost (for system) per Mile & 0.0668 & 0.0668 \\
\hline \multicolumn{3}{|c|}{\begin{tabular}{|l} 
Transmission Repairs (ATA VMRS 27) \\
\end{tabular}} \\
\hline Parts Cost & $1,906.79$ & $1,906.79$ \\
\hline Labor Hours & 68.6 & 68.6 \\
\hline Average Labor Cost & $3,430.00$ & $3,430.00$ \\
\hline Total Cost (for system) & $5,336.79$ & $5,336.79$ \\
\hline Total Cost (for system) per Bus & $1,067.36$ & $1,067.36$ \\
\hline Total Cost (for system) per Mile & 0.0350 & 0.0350 \\
\hline
\end{tabular}


Breakdown of Maintenance Costs by Vehicle System (continued)

\begin{tabular}{|c|c|c|c|}
\hline & $\begin{array}{l}\text { Diesel } \\
\text { All Data }\end{array}$ & $\begin{array}{l}\text { Diesel } \\
\text { Last ear }\end{array}$ & \\
\hline \multicolumn{3}{|c|}{ Inspections Only - no parts replacements (101) } & \\
\hline Parts Cost & 0.00 & 0.00 & \\
\hline Labor Hours & 518.0 & 518.0 & \\
\hline Average Labor Cost & $25,900.00$ & $25,900.00$ & \\
\hline Total Cost (for system) & $25,900.00$ & $25,900.00$ & \\
\hline Total Cost (for system) per Bus & $5,180.00$ & $5,180.00$ & \\
\hline Total Cost (for system) per Mile & 0.1698 & 0.1698 & \\
\hline \multicolumn{3}{|c|}{$\begin{array}{l}\text { Cab, Body, and Accessories Systems Repairs } \\
\text { (ATA VMRS 02-Cab and Sheet Metal, 50-Accessories, 71-Body) }\end{array}$} & \\
\hline Parts Cost & 797.55 & 797.55 & \\
\hline Labor Hours & 278.7 & 278.7 & \\
\hline Average Labor Cost & $13,935.00$ & $13,935.00$ & \\
\hline Total Cost (for system) & $14,732.55$ & $14,732.55$ & \\
\hline Total Cost (for system) per Bus & $2,946.51$ & $2,946.51$ & \\
\hline Total Cost (for system) per Mile & 0.0966 & 0.0966 & \\
\hline \multicolumn{3}{|c|}{ HVAC System Repairs (ATA VMRS 01) } & \\
\hline Parts Cost & $1,085.21$ & $1,085.21$ & \\
\hline Labor Hours & 98.4 & 98.4 & \\
\hline Average Labor Cost & $4,920.00$ & $4,920.00$ & \\
\hline Total Cost (for system) & $6,005.21$ & $6,005.21$ & \\
\hline Total Cost (for system) per Bus & $1,201.04$ & $1,201.04$ & \\
\hline Total Cost (for system) per Mile & 0.0394 & 0.0394 & \\
\hline \multicolumn{3}{|c|}{ Lighting System Repairs (ATA VMRS 34) } & \\
\hline Parts Cost & 204.52 & 204.52 & \\
\hline Labor Hours & 13.0 & 13.0 & \\
\hline Average Labor Cost & 650.00 & 650.00 & \\
\hline Total Cost (for system) & 854.52 & 854.52 & \\
\hline Total Cost (for system) per Bus & 170.90 & 170.90 & \\
\hline Total Cost (for system) per Mile & 0.0056 & 0.0056 & \\
\hline \multicolumn{4}{|c|}{ Frame, Steering, and Suspension Repairs (ATA VMRS 14-Frame, 15-Steering, 16-Suspension) } \\
\hline Parts Cost & 690.12 & 690.12 & \\
\hline Labor Hours & 32.5 & 32.5 & \\
\hline Average Labor Cost & $1,625.00$ & $1,625.00$ & \\
\hline Total Cost (for system) & $2,315.12$ & $2,315.12$ & \\
\hline Total Cost (for system) per Bus & 463.02 & 463.02 & \\
\hline Total Cost (for system) per Mile & 0.0152 & 0.0152 & \\
\hline \multicolumn{4}{|c|}{ 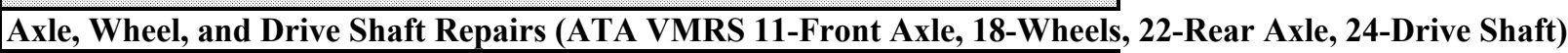 } \\
\hline Parts Cost & 126.00 & 126.00 & \\
\hline Labor Hours & 10.5 & 10.5 & \\
\hline Average Labor Cost & 525.00 & 525.00 & \\
\hline Total Cost (for system) & 651.00 & 651.00 & \\
\hline Total Cost (for system) per Bus & 130.20 & 130.20 & \\
\hline Total Cost (for system) per Mile & 0.0043 & 0.0043 & \\
\hline
\end{tabular}


Breakdown of Maintenance Costs by Vehicle System (continued)

\begin{tabular}{|c|c|c|}
\hline & \begin{tabular}{|l} 
Diesel \\
All Data
\end{tabular} & \begin{tabular}{|l} 
Diesel \\
Last ear
\end{tabular} \\
\hline \multicolumn{3}{|l|}{ Tire Repairs (ATA VMRS 17) } \\
\hline Parts Cost & 0.00 & 0.00 \\
\hline Labor Hours & 38.5 & 38.5 \\
\hline Average Labor Cost & $1,925.00$ & $1,925.00$ \\
\hline Total Cost (for system) & $1,925.00$ & $1,925.00$ \\
\hline Total Cost (for system) per Bus & 385.00 & 385.00 \\
\hline Total Cost (for system) per Mile & 0.0126 & 0.0126 \\
\hline
\end{tabular}

\section{Notes}

1. The engine/fuel-related systems were chosen to include only those systems of the vehicles that could be directly impacted by the selection of a fuel.

2. ATA VMRS coding is based on parts that were replaced. If there was no part replaced in a given repair, then the code was chosen by the system being worked on.

3. In general, inspections (with no part replacements) were only included in the overall totals (not by system). 101 was created to track labor costs for PMA inspections.

4. ATA VMRS 02-Cab and Sheet Metal represents seats, doors, etc.; ATA VMRS 50-Accessories represents things like fire extinguishers, test kits, etc.; ATA VMRS 71-Body represent mostly windows and windshields.

5. Average labor cost is assumed to be $\$ 50$ per hour.

6. Warranty costs are not included. 
Fleet Summary Statistics

2/16/2006

Washington Metropolitan Area Transit Authority (WMATA)

\section{Cummins CNG Study Group}

Fleet Operations and Economics

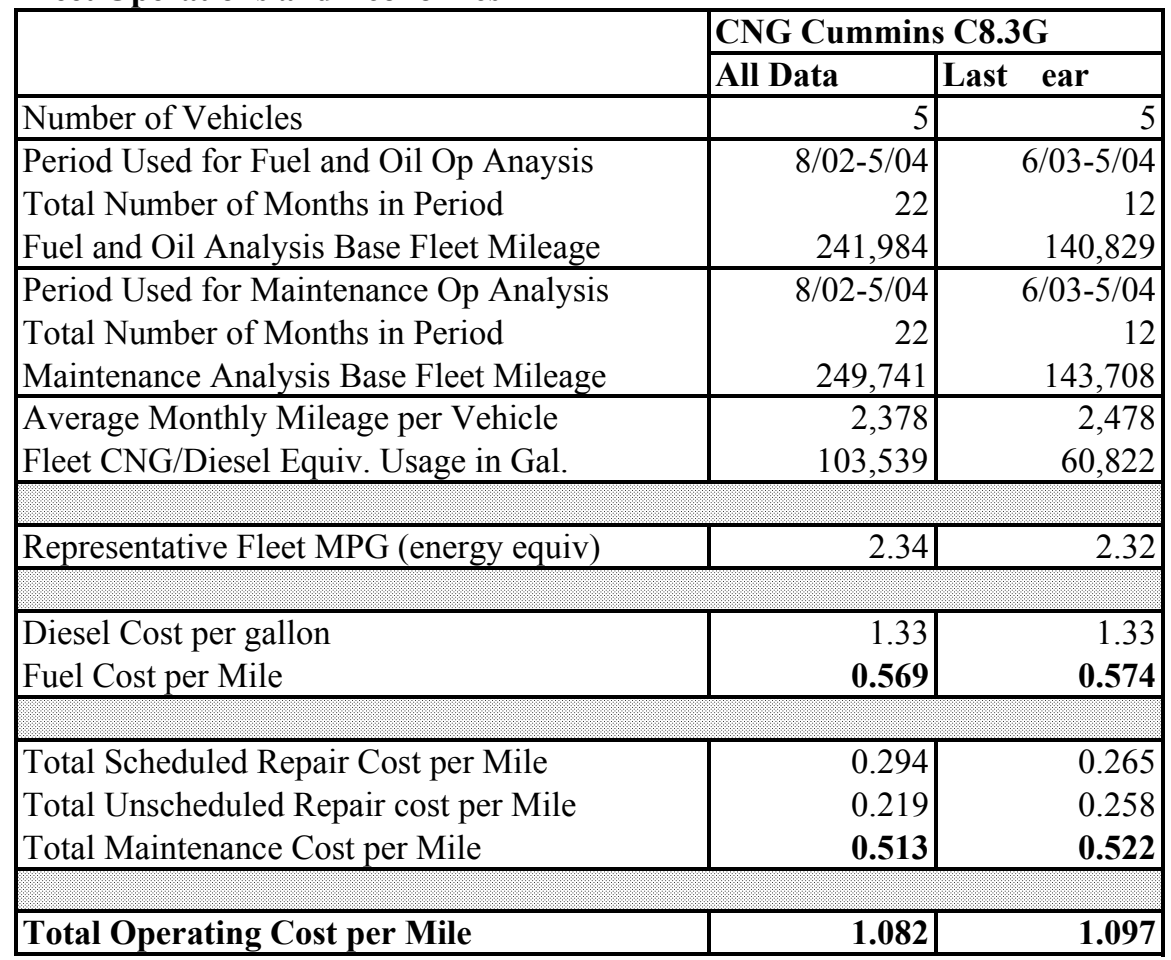

Maintenance Costs

\begin{tabular}{|l|r|r|}
\hline \multirow{2}{*}{} & \multicolumn{3}{|c|}{ CNG Cummins C8.3G } \\
\cline { 2 - 3 } & All Data & Last ear \\
\hline Fleet Mileage & 249,741 & \multicolumn{1}{c|}{143,708} \\
\hline Total Parts Cost & $18,678.74$ & $11,143.41$ \\
Total Labor Hours & 2188.1 & 1278.8 \\
Average Labor Cost & $109,407.00$ & $63,942.00$ \\
(@, \$50.00 per hour) & & \\
\hline & & \\
\hline Total Maintenance Cost & $128,085.74$ & $75,085.41$ \\
\hline Total Maintenance Cost per Bus & $25,617.15$ & $15,017.08$ \\
\hline Total Maintenance Cost per Mile & $\mathbf{0 . 5 1 3}$ & $\mathbf{0 . 5 2 2}$ \\
\hline
\end{tabular}


Breakdown of Maintenance Costs by Vehicle System

\begin{tabular}{|c|c|c|}
\hline & \multicolumn{2}{|c|}{ CNG Cummins C8.3G } \\
\hline & All Data & Last ear \\
\hline Fleet Mileage & \begin{tabular}{|r|}
249,741 \\
\end{tabular} & 143,708 \\
\hline \multicolumn{3}{|c|}{$\begin{array}{l}\text { Total Engine/Fuel-Related Systems } \\
\text { (ATA VMRS 30, 31, 32, 33, 41, 42, 43, 44, 45) }\end{array}$} \\
\hline Parts Cost & $11,653.75$ & $6,160.62$ \\
\hline Labor Hours & 433.1 & 264.8 \\
\hline Average Labor Cost & $21,655.00$ & $13,240.00$ \\
\hline Total Cost (for system) & $33,308.75$ & $19,400.62$ \\
\hline Total Cost (for system) per Bus & $6,661.75$ & $3,880.12$ \\
\hline Total Cost (for system) per Mile & $\mathbf{0 . 1 3 3 4}$ & 0.1350 \\
\hline \multicolumn{3}{|c|}{ Exhaust System Repairs (ATA VMRS 43) } \\
\hline Parts Cost & 75.00 & 75.00 \\
\hline Labor Hours & 23.2 & 22.2 \\
\hline Average Labor Cost & $1,160.00$ & $1,110.00$ \\
\hline Total Cost (for system) & $1,235.00$ & $1,185.00$ \\
\hline Total Cost (for system) per Bus & 247.00 & 237.00 \\
\hline Total Cost (for system) per Mile & 0.0049 & 0.0082 \\
\hline \multicolumn{3}{|c|}{ Fuel System Repairs (ATA VMRS 44) } \\
\hline Parts Cost & $3,065.70$ & $1,509.31$ \\
\hline Labor Hours & 49.8 & 25.5 \\
\hline Average Labor Cost & $2,490.00$ & $1,275.00$ \\
\hline Total Cost (for system) & $5,555.70$ & $2,784.31$ \\
\hline Total Cost (for system) per Bus & $1,111.14$ & 556.86 \\
\hline Total Cost (for system) per Mile & 0.0222 & 0.0194 \\
\hline \multicolumn{3}{|c|}{ Power Plant (Engine) Repairs (ATA VMRS 45) } \\
\hline Parts Cost & $3,254.93$ & $1,828.22$ \\
\hline Labor Hours & 72.1 & 51.3 \\
\hline Average Labor Cost & $3,605.00$ & $2,565.00$ \\
\hline Total Cost (for system) & $6,859.93$ & $4,393.22$ \\
\hline Total Cost (for system) per Bus & $1,371.99$ & 878.64 \\
\hline Total Cost (for system) per Mile & 0.0275 & 0.0306 \\
\hline \multicolumn{3}{|c|}{$\begin{array}{l}\text { Electrical System Repairs (ATA VMRS 30-Electrical General, } \\
\text { 31-Charging, 32-Cranking, 33-Ignition) }\end{array}$} \\
\hline Parts Cost & $2,973.88$ & $1,285.34$ \\
\hline Labor Hours & 154.1 & 85.4 \\
\hline Average Labor Cost & $7,705.00$ & $4,270.00$ \\
\hline Total Cost (for system) & $10,678.88$ & $5,555.34$ \\
\hline Total Cost (for system) per Bus & $2,135.78$ & $1,111.07$ \\
\hline Total Cost (for system) per Mile & 0.0428 & $\mathbf{0 . 0 3 8 7}$ \\
\hline
\end{tabular}


Breakdown of Maintenance Costs by Vehicle System (continued)

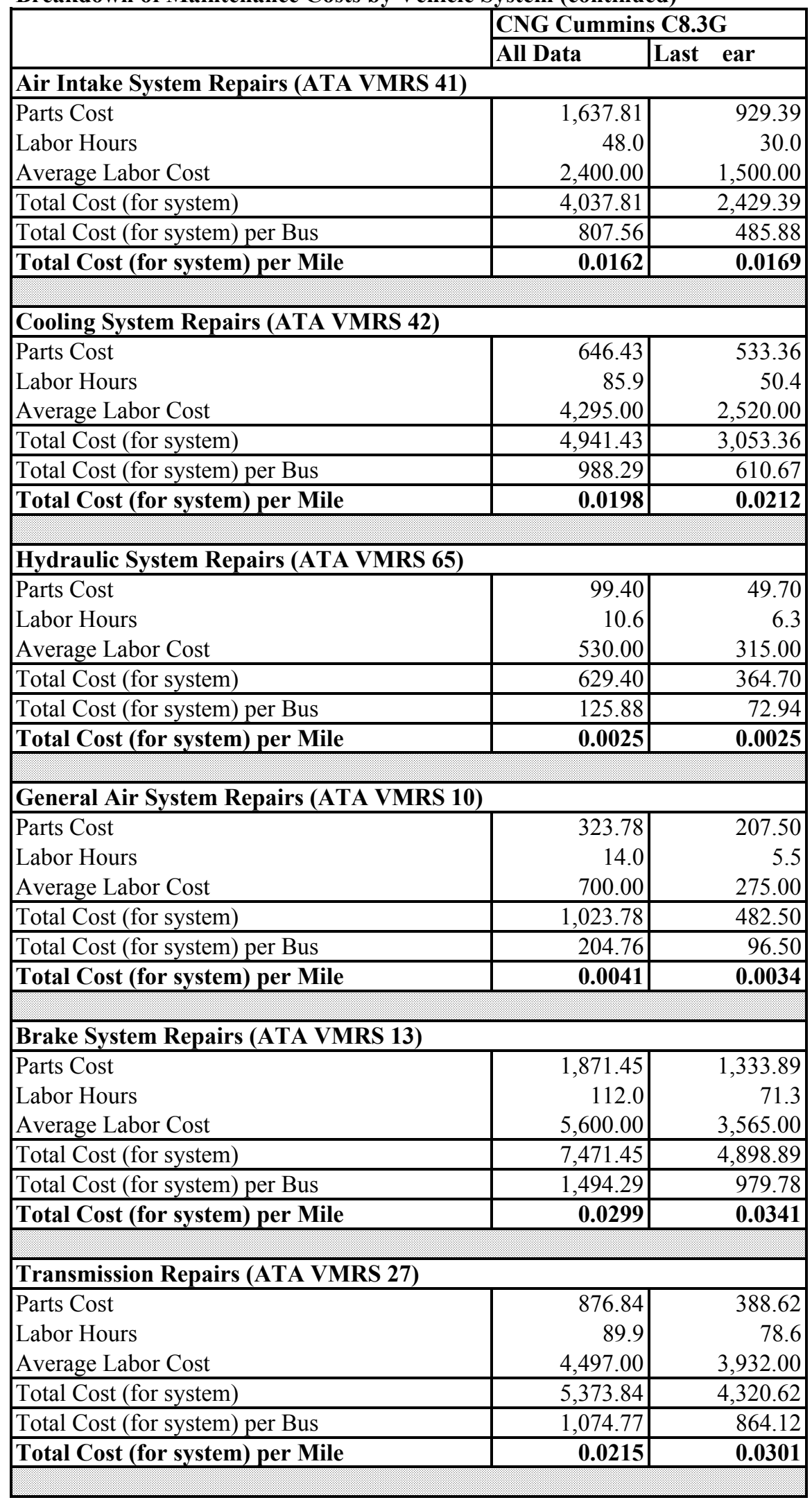


Breakdown of Maintenance Costs by Vehicle System (continued)

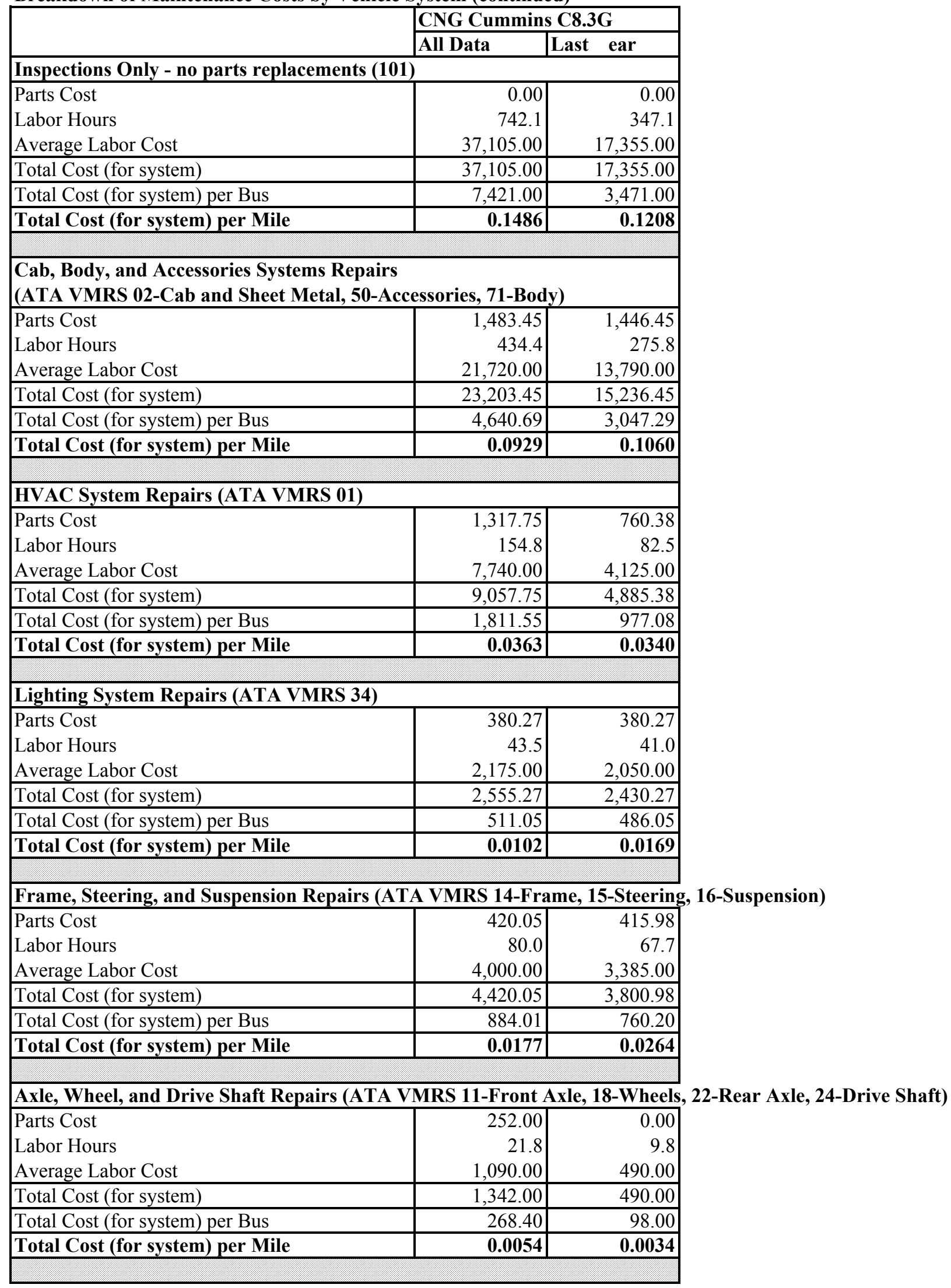


Breakdown of Maintenance Costs by Vehicle System (continued)

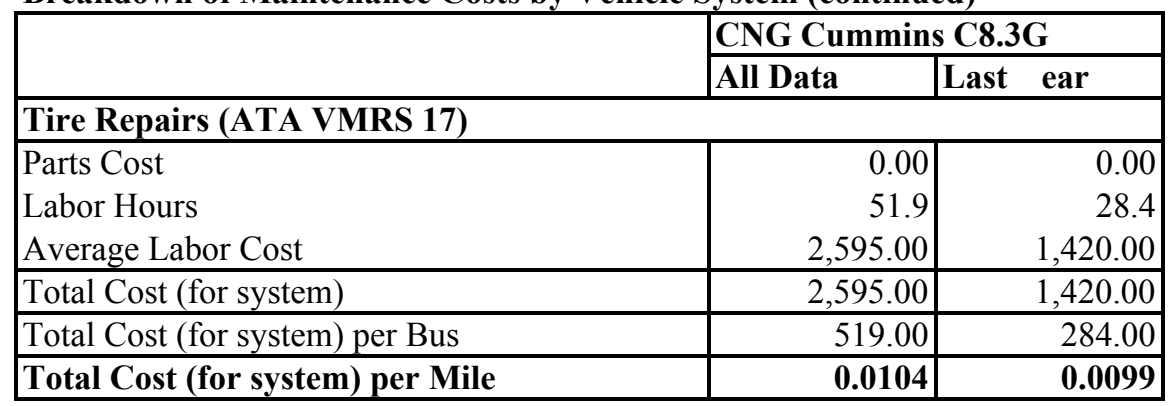

\section{Notes}

1. The engine/fuel-related systems were chosen to include only those systems of the vehicles that could be directly impacted by the selection of a fuel.

2. ATA VMRS coding is based on parts that were replaced. If there was no part replaced in a given repair, then the code was chosen by the system being worked on.

3. In general, inspections (with no part replacements) were only included in the overall totals (not by system). 101 was created to track labor costs for PMA inspections.

4. ATA VMRS 02-Cab and Sheet Metal represents seats, doors, etc.; ATA VMRS 50-Accessories represents things like fire extinguishers, test kits, etc.; ATA VMRS 71-Body represent mostly windows and windshields.

5. Average labor cost is assumed to be $\$ 50$ per hour.

6. Warranty costs are not included. 
Fleet Summary Statistics

12/13/2004

Washington Metropolitan Area Transit Authority (WMATA)

Deere CNG Study Group

Fleet Operations and Economics

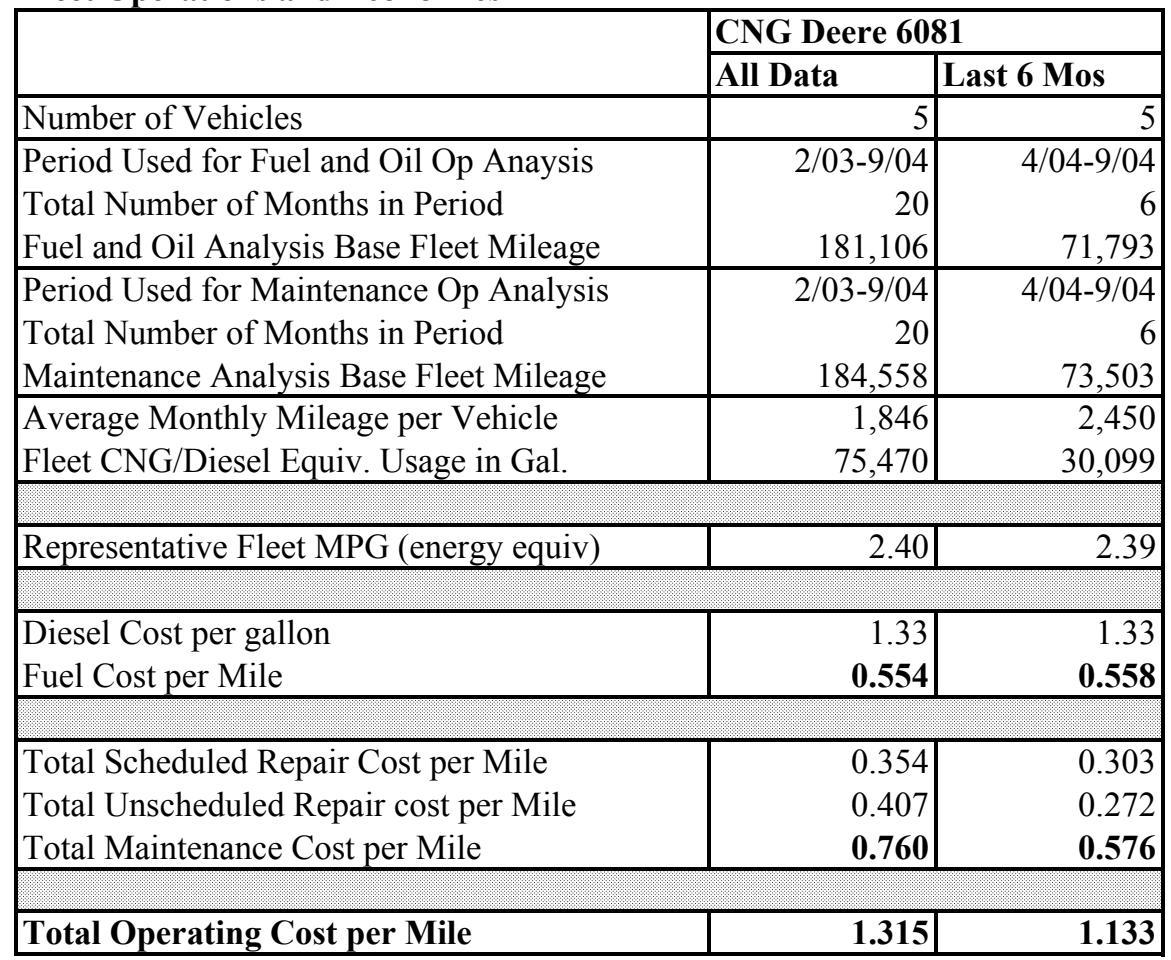

Maintenance Costs

\begin{tabular}{|l|r|r|}
\hline \multicolumn{2}{|c|}{} & \multicolumn{2}{|c|}{ CNG Deere 6081 } \\
\cline { 2 - 3 } \multicolumn{1}{|c|}{ All Data } & Last 6 Mos \\
\hline Fleet Mileage & 184,558 & \multicolumn{1}{c|}{73,503} \\
\hline Total Parts Cost & $16,637.35$ & $5,441.49$ \\
Total Labor Hours & 2474.1 & 737.4 \\
Average Labor Cost & $123,705.00$ & $36,872.00$ \\
(@ \$50.00 per hour) & & \\
\hline & & \\
\hline Total Maintenance Cost & $140,342.35$ & $42,313.49$ \\
\hline Total Maintenance Cost per Bus & $28,068.47$ & $8,462.70$ \\
\hline Total Maintenance Cost per Mile & $\mathbf{0 . 7 6 0}$ & $\mathbf{0 . 5 7 6}$ \\
\hline
\end{tabular}


Breakdown of Maintenance Costs by Vehicle System

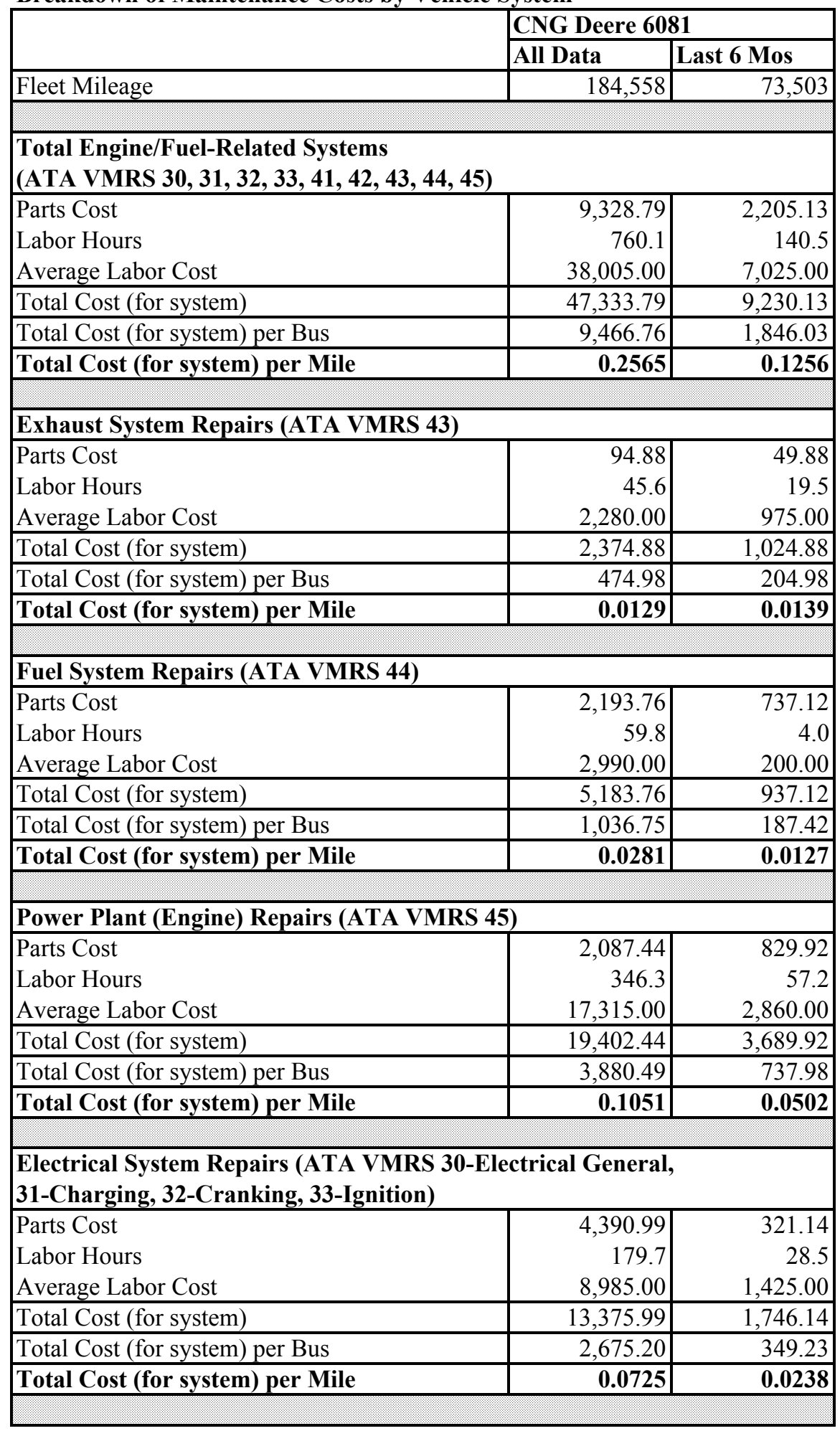


Breakdown of Maintenance Costs by Vehicle System (continued)

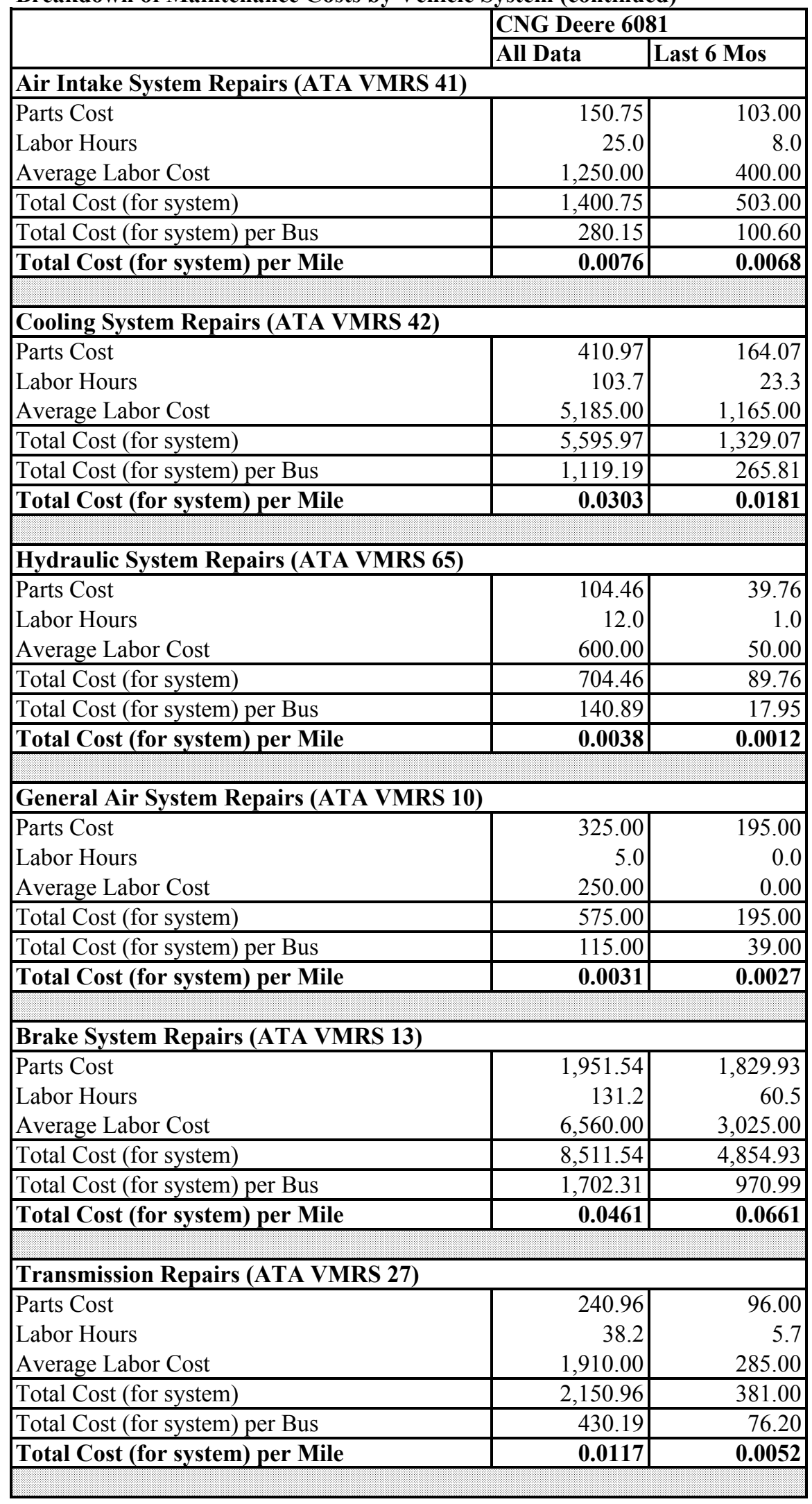


Breakdown of Maintenance Costs by Vehicle System (continued)

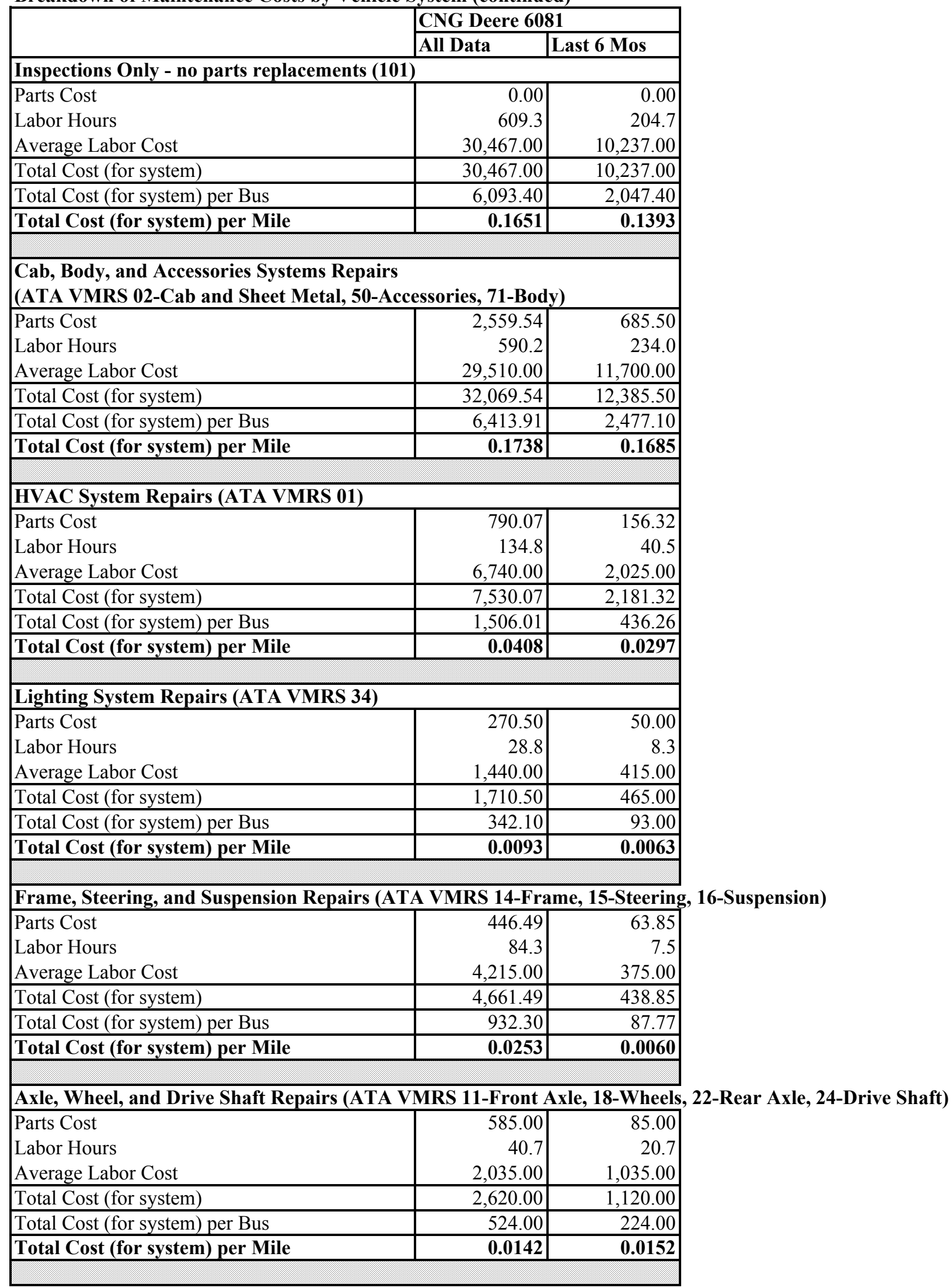


Breakdown of Maintenance Costs by Vehicle System (continued)

\begin{tabular}{|c|c|c|}
\hline & \multicolumn{2}{|c|}{ CNG Deere 6081} \\
\hline & All Data & Last 6 Mos \\
\hline \multicolumn{3}{|l|}{ Tire Repairs (ATA VMRS 17) } \\
\hline Parts Cost & 35.00 & 35.00 \\
\hline Labor Hours & 39.5 & 14.0 \\
\hline Average Labor Cost & $1,975.00$ & 700.00 \\
\hline Total Cost (for system) & $2,010.00$ & 735.00 \\
\hline Total Cost (for system) per Bus & 402.00 & 147.00 \\
\hline Total Cost (for system) per Mile & 0.0109 & 0.0100 \\
\hline
\end{tabular}

\section{Notes}

1. The engine/fuel-related systems were chosen to include only those systems of the vehicles that could be directly impacted by the selection of a fuel.

2. ATA VMRS coding is based on parts that were replaced. If there was no part replaced in a given repair, then the code was chosen by the system being worked on.

3. In general, inspections (with no part replacements) were only included in the overall totals (not by system). 101 was created to track labor costs for PMA inspections.

4. ATA VMRS 02-Cab and Sheet Metal represents seats, doors, etc.; ATA VMRS 50-Accessories represents things like fire extinguishers, test kits, etc.; ATA VMRS 71-Body represent mostly windows and windshields.

5. Average labor cost is assumed to be $\$ 50$ per hour.

6. Warranty costs are not included. 


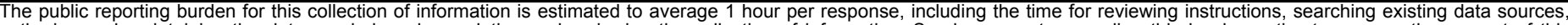

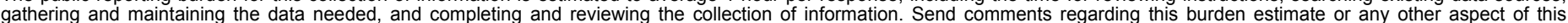

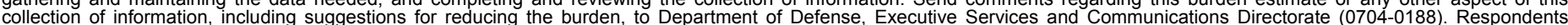

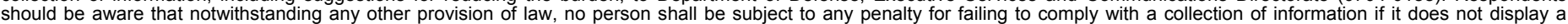

currently alid OMB control number.

PLEASE DO NOT RETURN YOUR FORM TO THE ABOVE ORGANIZATION.

\begin{tabular}{l|l|l|l} 
1. REPORT DATE (DD-MM-YYYY) & 2. REPORT TYPE & 3. DATES COVERED (FrOm - TO)
\end{tabular}

April 2006

Technical Report

4. TITLE AND SUBTITLE

Washington Metropolitan Area Transit Authority: Compressed

Natural Gas Transit Bus Evaluation

5a. CONTRACT NUMBER

DE-AC36-99-G010337

5b. GRANT NUMBER

5c. PROGRAM ELEMENT NUMBER

6. AUTHOR(S)

K. Chandler, E. Eberts, M. Melendez

5d. PROJECT NUMBER

NREL/TP-540-37626

5e. TASK NUMBER

FC05.9000

5f. WORK UNIT NUMBER
7. PERFORMING ORGANIZATION NAME(S) AND ADDRESS(ES)

National Renewable Energy Laboratory

1617 Cole Blvd.

Golden, CO 80401-3393

9. SPONSORING/MONITORING AGENCY NAME(S) AND ADDRESS(ES)
8. PERFORMING ORGANIZATION REPORT NUMBER

NREL/TP-540-37626
10. SPONSOR/MONITOR'S ACRONYM(S) NREL

11. SPONSORING/MONITORING AGENCY REPORT NUMBER

12. DISTRIBUTION AVAILABILITY STATEMENT

National Technical Information Service

U.S. Department of Commerce

5285 Port Royal Road

Springfield, VA 22161

13. SUPPLEMENTARY NOTES

14. ABSTRACT (Maximum 200 Words)

Through the evaluation of compressed natural gas (CNG) powered transit buses at Washington Metropolitan Area Transit Authority (WMATA), the report's objective is to provide a reasonable comparison between between currently available CNG and standard diesel transit buses.

15. SUBJECT TERMS

compressed natural gas; CNG; transit buses; Washington Metropolitan Area Transit Authority; WMATA; natural gas vehicles

\begin{tabular}{|c|c|c|}
\hline $\begin{array}{l}\text { a. REPORT } \\
\text { Unclassified }\end{array}$ & $\begin{array}{l}\text { b. ABSTRACT } \\
\text { Unclassified }\end{array}$ & $\begin{array}{l}\text { c. THIS PAGE } \\
\text { Unclassified }\end{array}$ \\
\hline
\end{tabular}

\begin{tabular}{|c|c|}
\hline $\begin{array}{l}\text { 7. LIMITATION } \\
\text { OF ABSTRACT }\end{array}$ & $\begin{array}{l}\text { 18. NUMBER } \\
\text { OF PAGES }\end{array}$ \\
\hline UL & \\
\hline
\end{tabular}

19a. NAME OF RESPONSIBLE PERSON

19b. TELEPHONE NUMBER (Include area code) 